UNIVERSIDADE DE BRASÍLIA

FACULDADE DE MEDICINA

PÓS-GRADUAÇÃO EM PATOLOGIA MOLECULAR

\title{
Expressão de antígenos virais fusionados a uma proteína formadora de corpos de oclusão de um vírus de inseto
}

Leonardo Assis da Silva

Orientador: Bergmann Morais Ribeiro

Brasília, 2016 


\section{Expressão de antígenos virais fusionados a uma proteína formadora de corpos de oclusão de um vírus de inseto}

Leonardo Assis da Silva

Orientador: Bergmann Morais Ribeiro

Tese apresentada ao Programa de PósGraduação em Patologia Molecular Faculdade de Medicina, da Universidade de Brasília como parte dos requisitos para obtenção do título de Doutor em Patologia Molecular.

Brasília, 2016 
"Se não puder voar, corra. Se não puder correr, ande. Se não puder andar, rasteje, mas continue em frente de qualquer jeito".

Martin Luther King

"Suba o primeiro degrau com fé. Não é necessário que você veja toda a escada.

Apenas dê o primeiro passo".

Martin Luther King

"If you can dream it, you can do it".

"Follow your dreams, work hard, practice and persevere". 
A minha familia A minha amiga e namorada Brenda $R$. de Camargo Aos meus sogros Ao professor Bergmann M. Ribeiro A minha vontade de vencer e superar as dificuldades da vida, com muita alegria de perseverança.

Dedico 
Agradeço a minha família, minha fantástica família (minha irmã, Luciana; meus irmãos, Dê e Moca; minha mãe, Vera e meu pai Zé) por todo apoio nessa grande caminhada. Vocês sabem o quanto foi difícil esta busca! As minhas avós que moldaram meu caráter, exemplos de mulher (Tereza e Inácia, in memoriam)

A minha namorada, Brenda Rabello de Camargo, pela amizade, companheirismo, parceria, por me ensinar muitas coisas a cada dia, por me apoiar e e respeitar minhas decisões, obrigado por estar ao meu lado, sou muito feliz ao seu lado, te amo!

Agradeço ao meu professor e orientador, em quem me espelho e respeito como homem e profissional, prof. Dr. Bergmann Morais Ribeiro. Homem íntegro, ético, profissional, de índole inquestionável e sábio. É bom poder contar com o senhor sempre; com sua confiança e torcida. Espero nunca o decepcionar!

A minha segunda família, fantástica como a biológica (minha mãe-sogra, dona Mara, meu pai-sogro, seu Rabello, minha cunhada, Bia e cunhado, Alê). Obrigado pelo apoio emocional e auxilio por esses últimos anos, família que admiro, respeito e me espelho.

Ao meu grande amigo Marcelo Eiras, por ter depositado toda a confiança, expectativa, e inspiração para me tornar um grande pesquisador. Obrigado pela amizade e confiança!

Ao meu grande amigo-irmão Daniel, que admiro muito e me espelho, como pessoa e profissional, exemplo de vida e profissionalismo. Obrigado por ser meu amigo e ter me ensinado nesses anos todos sobre ciência e vida!

Aos meus amigos do laboratório de baculovírus e de vida: Roberto, Fabrício, Fernando, Ana Maria, Athos, Rayane e Mariana. É bom poder contar sempre com vocês!

Agradeço a prof ${ }^{\mathrm{a}}$. Dr ${ }^{\mathrm{a}}$. Anamélia Lorezentti Bocca e seus alunos Márcio e Raffael pelo apoio e ajuda nos experimentos imunológicos. Obrigado pela força! 
Aos meus amigos da Wageningen University: Methap (Turquia), Lucrézia (Itália), Han (China), Fenqgiao (China), Giel (Holanda), Ioana (Romenia/ltália), Mark (Holanda), Sandra (Holanda), Marleen (Holanda), Corien (Holanda), Corinne (Holanda), Els (Holanda), Dick (Holanda), Jhon (Quenia), Tanya (Rússia), Fernando (Rio de Janeiro), Liz (São José dos Campos), Angel (Espanha), Sander (Holanda), Juliano (Florianópolis). Pelos momentos maravilhosos que passei na minha caminhada pela Europa! Obrigado pela paciência e ajuda!

Ao pessoal do Instituto Adolfo Lutz e Instituto Biológico por despertar e iniciar meu amor pela pesquisa!

Agradeço aos componentes da banca de ambos qualificação e de defesa de tese.

Agrdeço a minha supervisora de doutorado sanduíche prof.dr. MM (Monique) van Oers, a todos os pesquisadores do laboratório de virologia e a Wageningen University (WUR) Holanda por me receber durante meu período sanduíche.

Agradeço a Universidade de Brasília por ter-me aberto esta porta para o fantástico e apaixonante mundo da ciência.

Ao CNPq.

Ao Brasil, meu fantástico país. 


\section{Sumário}

Índice de figuras......................................................................................... vii

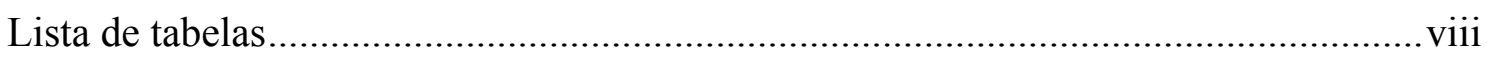

Abreviações e símbolos utilizados.......................................................................... viii

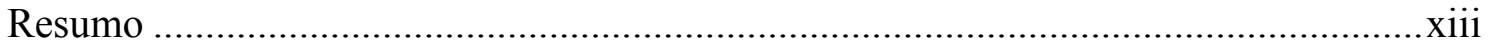

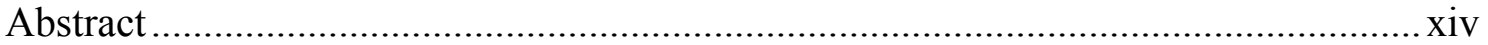

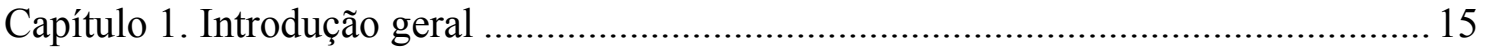

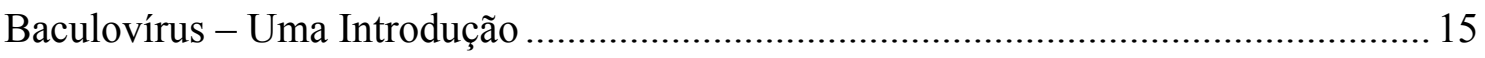

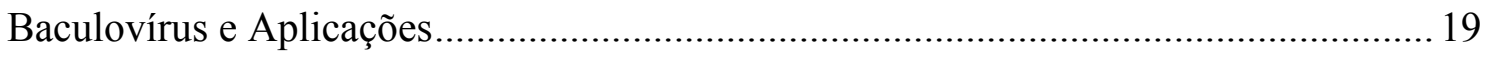

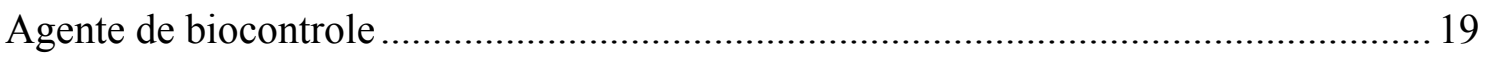

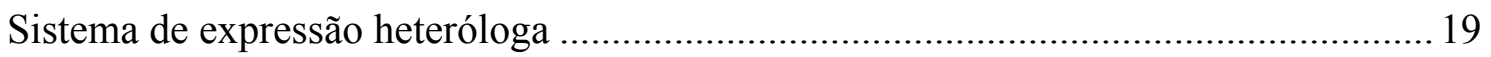

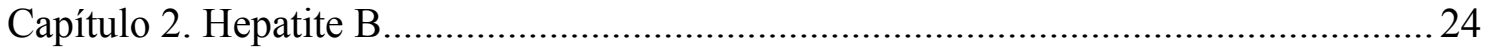

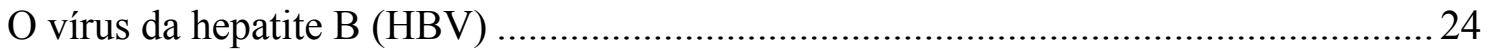

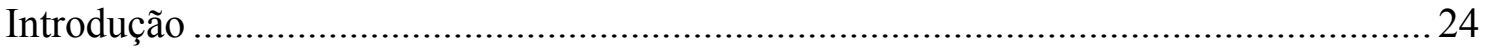

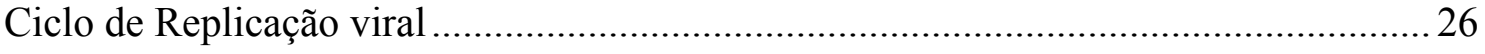

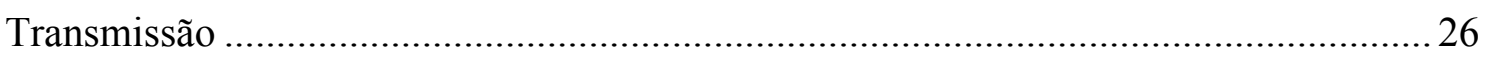

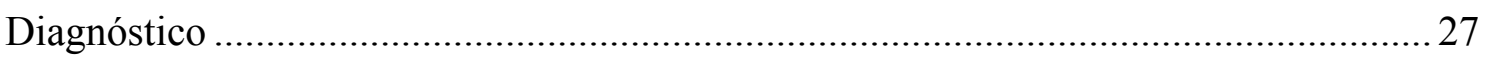

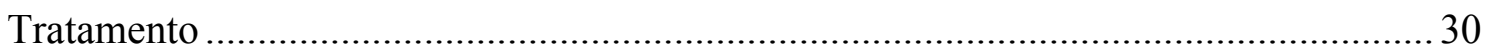

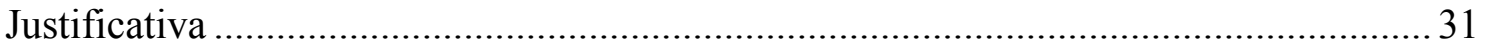

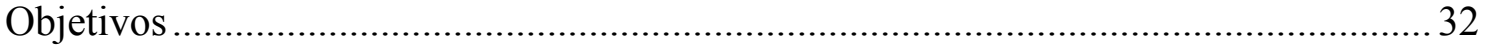

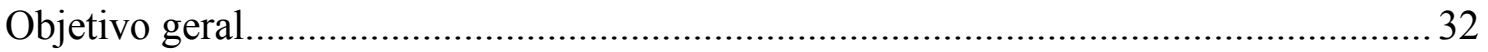

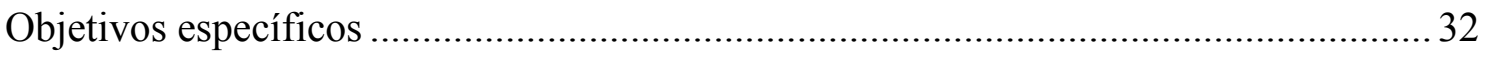

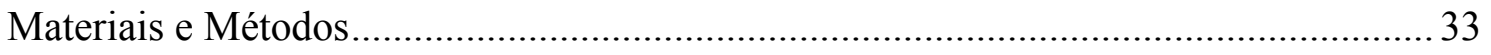

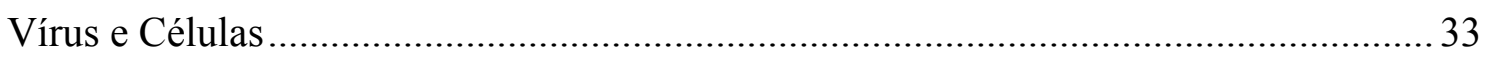

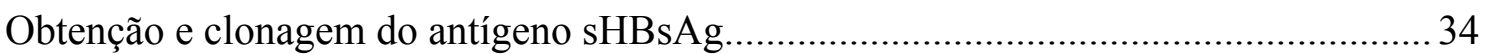

Clonagem do gene sHBsAg na região 3' do gene polh do AcMNPV e em um vetor

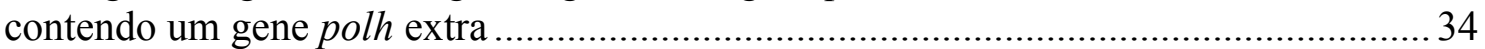

Obtenção de baculovírus recombinantes para expressão da região sHBsAg fusionada à

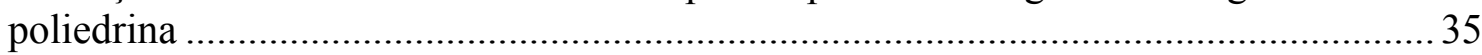

Produção in vitro da proteína quimera sHBsAg ................................................................ 36

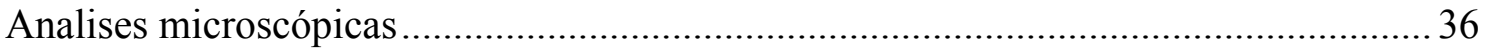

Análise da expressão e purificação das proteínas recombinantes em larvas de

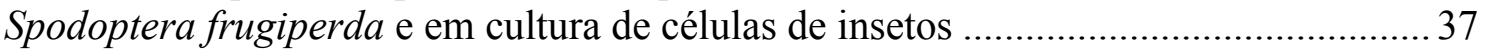

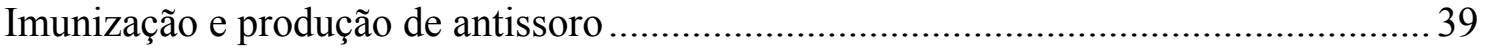

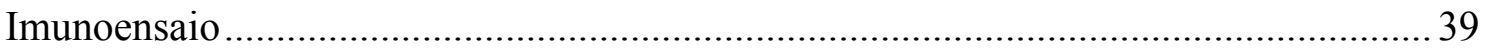

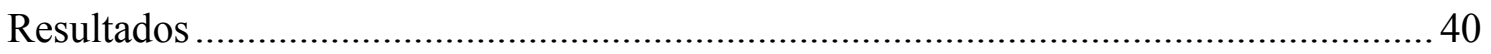

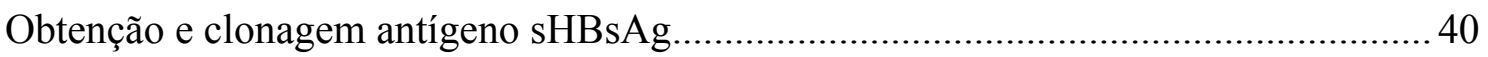


Construção do vetor de transferência pFastAcPH3-sHBsAg e pFastBac1/AccI-PSX-

6xHis-sHBsAg-AcPH

Construção do vírus contendo as fusões PH3sHBsAg e AccI-PSX-6xHis-sHBsAg$\mathrm{AcPH}$

Análise da expressão da proteína recombinante e estrutural de possíveis cristais da proteína quimera sHBsAg em insetos

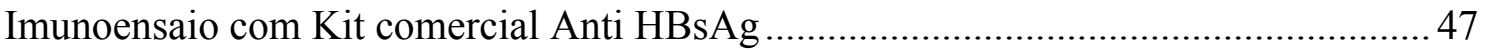

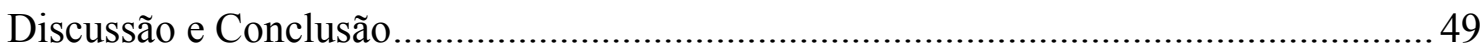

Capítulo 3. Efeitos imunológicos de um peptídeo da glicoproteína do vírus da raiva pela

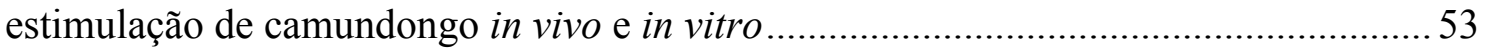

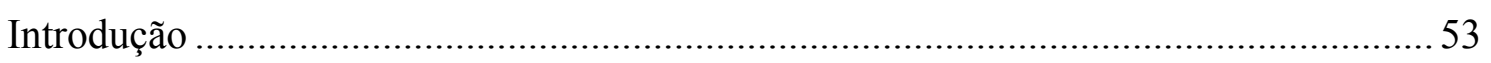

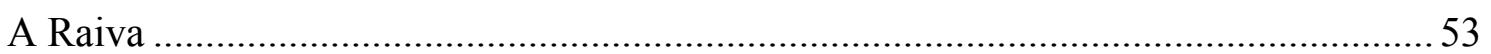

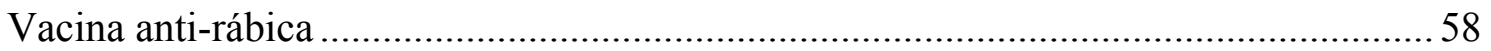

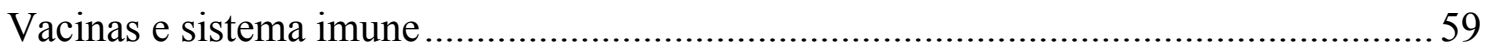

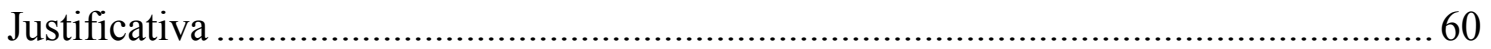

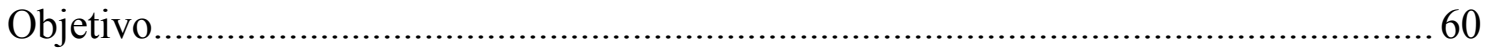

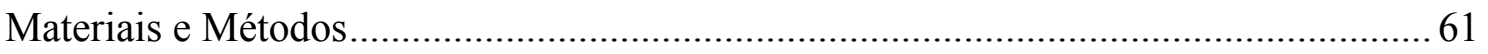

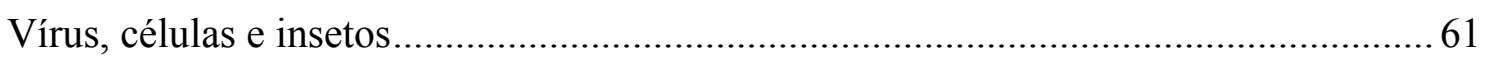

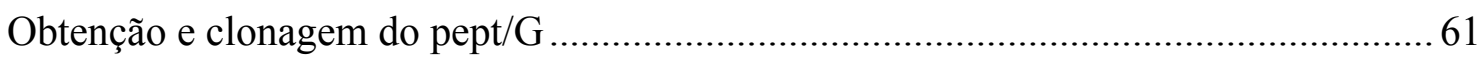

Clonagem do pept/G na região 5' do gene da polh do AcMNPV ..................................6. 62

Obtenção de baculovírus recombinante para expressão do pept/G fusionada à poliedrina

Produção in vitro da proteína quimérica pept/G fusionada à poliedrina ........................63

Analises da expressão da proteína recombinante em células de inseto e análise ultraestrutural de possíveis cristais recombinantes.

Análise da expressão das proteínas recombinantes em larvas de Spodoptera frugiperda e

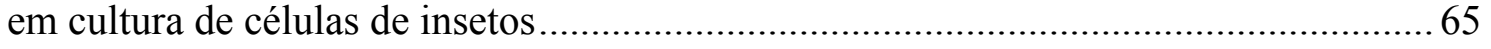

Imunização, produção de anticorpos e citocinas in vivo .................................................6 66

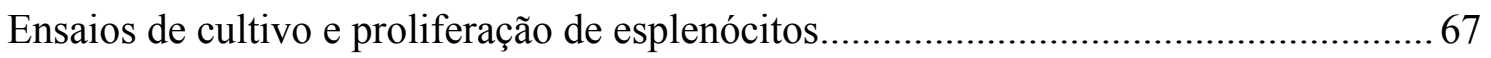

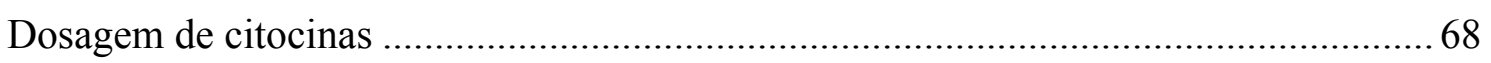

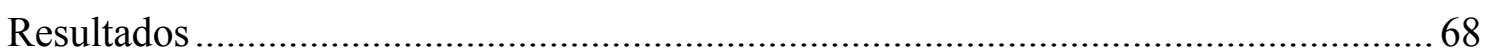

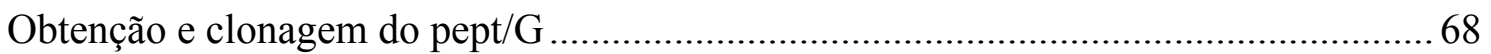

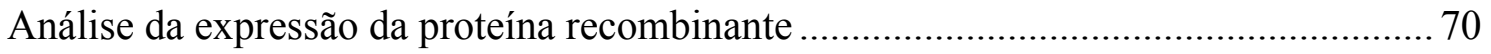

Análise da purificação dos cristais recombinantes ...................................................... 72

Ensaio de proliferação celular e análises de citocinas ................................................... 74

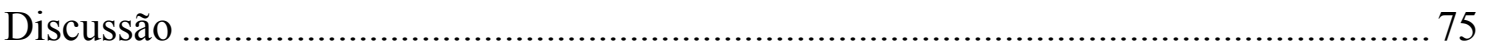

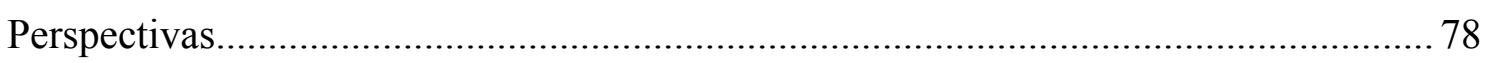

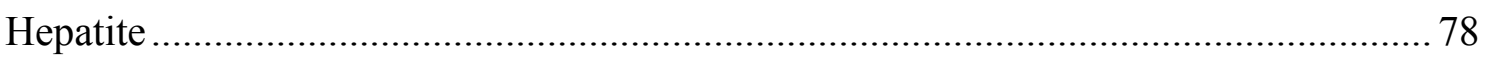

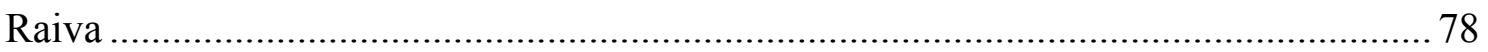




\section{Índice de figuras}

Figura 1. O ciclo de infecção de um baculovírus do grupo nucleopoliedrovírus (NPV) em um hospedeiro lepidóptero. 17

Figura 2. Esquema mostrando o sistema Bac-to-Bac da Invitrogem ...............23

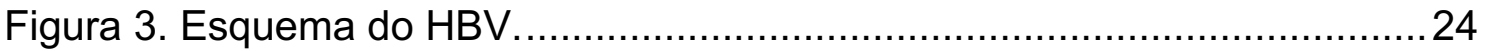

Figura 4. Representação esquemática da organização do genoma HBV. .......25

Figura 5. Marcadores sorológicos e molecular da infecção pelo HBV..............29

Figura 7. Esquema das duas regiões usadas para fusão da região 'small' do antígeno $\mathrm{HBsAg}$ à poliedrina. 35

Figura 8. Esquema mostrando a sequência de construção do vetor pGemHBsAg. 41

Figura 9. Construção do vetor de transferência pFastAcPH3sSHBsAg. 42

Figura 10. ( $a, b$ e c) Esquema da construção do vetor de transferência pFastBac1/Accl-PSX-6xHis-sHBsAg-AcPH (com o gene extra da poliedrina do AcMNPV) 42

Figura 11. Confirmação da construção do bacmídeo vAcPHHBs. 43

Figura 12. Confirmação da construção do bacmideo bacvAcHBsPH2. 44

Figura 13. Análise do efeito citopático da infecção de células Tn5B com diferentes baculovírus a 72 h.p.i.

Figura 14. Análise da expressão da proteína recombinante sHBsAg em células de inseto infectadas com o baculovírus recombinante vAcPHHBs e vAcHBsPH2.

Figura 15. Analise ultraestrutural dos corpos de oclusão derivados de larvas de

S. frugiperda infectadas pelos vírus recombinantes. 47

Figura 16. ELISA utilizando Kit Laboratorial Anti HBsAg Qualitativo e Quantitativo da empresa Wama Diagnóstica. 48

Figura 17. Ciclos epidemiológicos de transmissão da raiva no Brasil. 56

Figura 18. Esquemas dos genes usados para fusão da polh com o pept/G e sequências de aminoácidos deduzidas a partir da sequência do DNA.. ...69

Figura 19. Confirmação da construção do vírus vAc-pept/G-polh. 70 
Figura 20. Análise do efeito citopático da infecção de células Tn5B com diferentes baculovírus a 72 h.p.i.

Figura 21. Análise da expressão de proteínas recombinantes em células de inseto infectadas com diferentes baculovírus recombinantes.

Figura 22. Purificação e analise ultraestrutural dos corpos de oclusão derivados de insetos infectados pelos baculovirus recombinantes vAc-6xHis-polh e vAcPEP/polh. 73

Figura 23. Análise da expressão de proteínas recombinantes. 73

Figura 24. Ensaio de proliferação celular pelo método CFSE. 74

\section{Lista de tabelas}

Tabela 1. Genótipos e distribuição geográfica do HBV (adaptado de ARAUZRUIZ et al., 2002) Error! Bookmark not defined.

Tabela 2. Iniciadores utilizados no trabalho 44

Tabela 3. Iniciadores utilizados no trabalho 62

\section{Abreviações e símbolos utilizados}

$\begin{array}{ll}\% & \text { por cento } \\ < & \text { menor que } \\ { }^{\circ} \mathrm{C} & \text { grau Celsius } \\ 6 \mathrm{xHis} & \text { cauda de hexa-histidina }\end{array}$

AcMNPV Baculovírus Autographa californica multiple nucleopolyhedrovirus

$\mathrm{AcPH} \quad$ poliedrina do baculovírus AcMNPV

Ad adenovírus

AdC adenovírus de chimpanzés

AgMNPV Baculovírus Anticarsia gemmatalis multiple nucleopolyhedrovirus
ALT
Alanina aminotransferase
AST
Aspartato aminotransferase
Bac
do inglês, "Bacterial artificial chromosome" 
BCIP

BmNPV

BSA

BTI-Tn5B1-4

BV

CFSE

$\mathrm{CHC}$

$\mathrm{cm}^{2}$

CMV

ConA

$\mathrm{CsCl}$

D.O.

$\mathrm{dd} \mathrm{H}_{2} \mathrm{O}$

DNA

E. coli

ECV

EIA

ELISA

ERIG

$\mathrm{F}$

$g$

GP64 sigla do inglês, "5-Bromo-4-chloro-3-indolyl phosphate"

Baculovírus Bombyx mori nucleopolyhedrovirus

albumina sérica bovina

linhagem derivada do lepidóptero $T$. ni

do inglês, "budded vírus"

citoplasmático fluorecente 5,6-carboxifluoresceína diacetato succinimidil éster

Carcinoma Hepatocelular

centímetro quadrado

Citomegalovirus

Concanavalina A

Cloreto césio

Densidade óptica

Água bidestilada

Ácido desoxirribonucleico

Escherichia coli

do inglês, "extracellular vírus"

do inglês, "enzyme immunoassays"

do inglês, "Enzyme Linked Immunosorbent Assay"

Imunoglobulina anti-rábica Equina

primer "Foward"

grama

Glicoproteina de 64 kilodaltons (proteína de envelope viral)

GLICOPROTEÍNA G Glicoproteina viral

GVs

Granulovirus

$\mathrm{h}$

horas

h p.i.

horas pós-infecção

$\mathrm{H}_{2} \mathrm{SO}_{4}$

ácido sulfúrico

HAV

Vírus Hepatite A

HB

Hepatite B

$\mathrm{HBcAg}$

antígeno do core do HBV

$\mathrm{HBeAg}$

antígeno do envelope do HBV

HBsAg

antígeno de superfície do HBV

HBV

Vírus da Hepatite B 


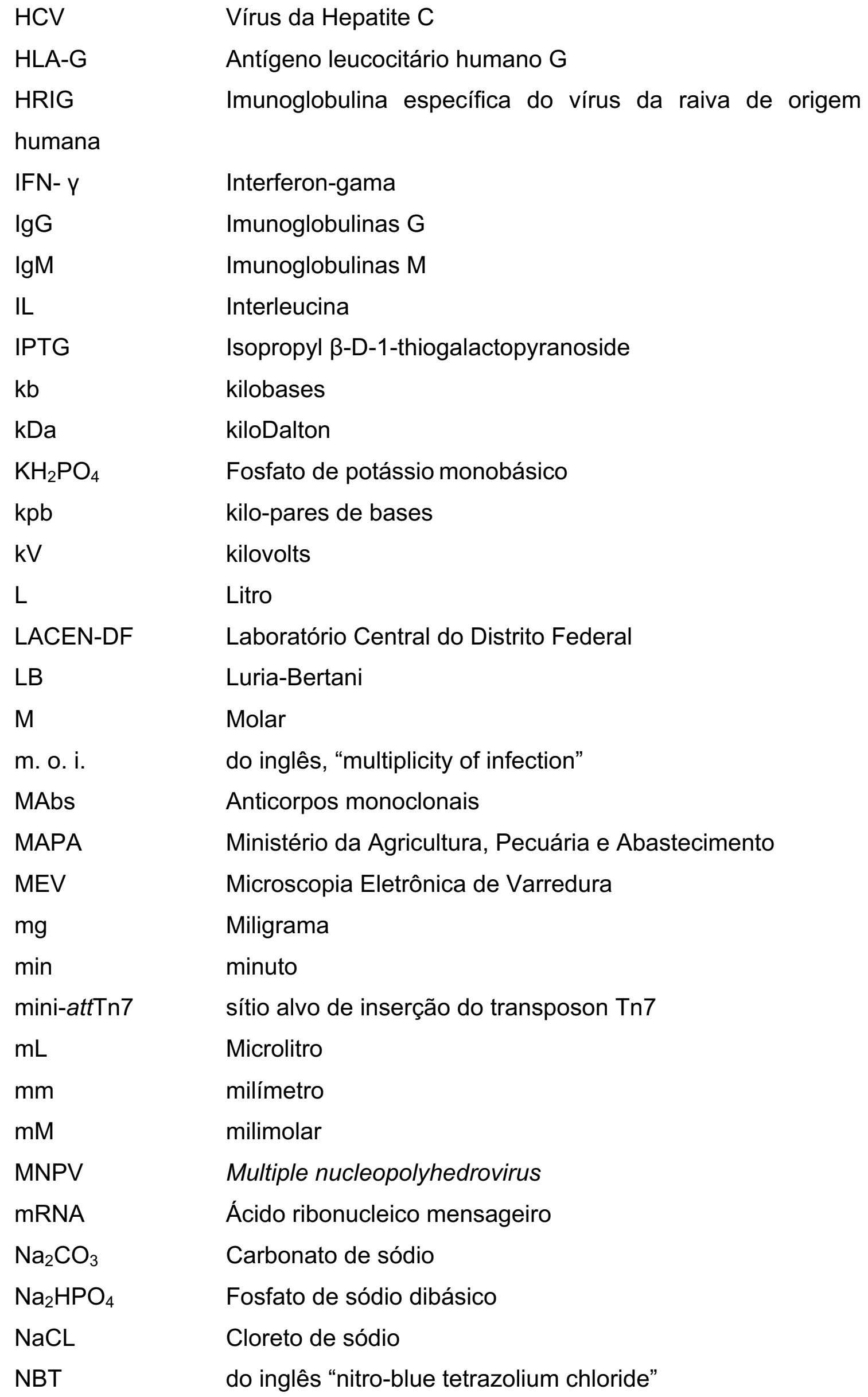


nanogramas

NO

Óxido Nítrico

NPVs

Nucleopolyhedrovirus

$\mathrm{OB}$

do inglês, "occlusion body"

ODV

do inglês, do inglês "occluded vírus"

ORFs

do inglês, "open reading frame"

$\mathrm{p} / \mathrm{v}$

relação peso por volume

PAGE

do inglês, "polyacrylamide gel electrophoresis"

$\mathrm{pb}$

pares de bases

PBS

do inglês, "Phosphate buffered saline"

PCR

$\mathrm{pg} / \mathrm{ml}$

Reação em cadeia da polimerase

$\mathrm{pH}$

relação picograma por militro

PIB

concentração de íon hidroxônio livre

PSX

do inglês, ,polyhedral inclusion bodies"

Att

P - poliedrina; S - promotor Syn; X - promotor XIV

pSyn

do inglês, "attachment"

pXIV

promotor sintético da fase tardia

$\mathrm{R}$

$\mathrm{Pept} / \mathrm{G}$

promotor da poliedrina modificado

primer "Reverse"

RIG

peptídeo imunogênico da glicoproteína do vírus da Raiva Imunoglobulina específica do vírus da raiva

RLR

do inglês, "RIG-I-like receptors"

RNA

ácido ribonucleico

RPMI

do inglês, "Roswell Park Memorial Institute médium"

POLH

Poliedrina

S

do inglês, "small"

SDS

do inglês, "sodium dodecyl sulfate"

SDS-PAGE

do inglês, "sodium dodecyl sulfate polyacrylamide gel

electrophoresis"

SNC

sistema nervoso central

SNPV

Single nucleopolyhedrovirus

SP6

promotor de uma RNA polimerase de fago

SV40

do inglês, "Simian vacuolating virus 40"

T7

promotor do fago T7 


$\begin{array}{ll}\text { TLR } & \text { do inglês, "Toll-like receptors" } \\ \text { Tn7 } & \text { braço homólogo marcador do transposon Tn7 } \\ \text { TNF- } \alpha & \text { Fator de necrose tumoral alfa } \\ \text { Tris } & \text { 2-amino-2-hidroximetil-propano-1,3-diol } \\ \text { Tris-HCl } & \text { TRIS hidrocloreto } \\ \text { U } & \text { Unidade de enzima } \\ \text { UTR } & \text { Região não-traduzida } \\ \text { UV } & \text { ultravioleta } \\ \text { V } & \text { Volts } \\ \text { v/v } & \text { relação volume/volume } \\ \text { vAc } & \text { recombinante da espécie AcMNPV } \\ \text { HBV } & \text { Vírus da hepatite B } \\ \text { VLP } & \text { do ingês, "virus-like particles" } \\ \text { V-RG } & \text { estirpe de vírus vaccínia de Copenhagen } \\ \text { w/v } & \text { relação peso por volume } \\ \text { x } & \text { velocidade de sedimentação gravitacional } \\ \text { X-Gal } & \text { 5-bromo-4-cloro-3-indolil-D-galactopiranosídeo } \\ \mu g & \text { micrograma } \\ \mu L & \text { microlitro } \\ \mu m & \text { micrômetro }\end{array}$




\section{Resumo}

Baculovírus são vírus de DNA de dupla fita circular que infectam insetos, inicialmente utilizados apenas como controle biológico por serem capazes de eliminar insetos-praga associados à agricultura. Nas décadas de 70 e 80 , seu potencial como ferramenta para expressão de proteínas heterólogas começou a ser explorado. Hoje, os baculovírus têm sido utilizados amplamente para expressar antígenos de uso vacinal ou diagnóstico e até mesmo utilizados como potenciais vetores de terapia gênica e vacinas de DNA. Sua biossegurança é garantida pelo fato de não serem capazes de se replicar em células de mamífero. Entretanto, são capazes de penetrar nessas células, além de apresentarem propriedades imunoestimulatórias. Deste modo, inúmeras proteínas de importância médica e econômica foram expressas em níveis elevados aplicando desse sistema. Atualmente, não existem indústrias ou empresas nacionais disponíveis para a produção escalonável do antígeno de superfície HBsAg. Perante disso, os insumos são importados tanto para fins vacinais como para o diagnóstico. A vacina anti-rábica altualmente é constituída por suspensões de vírus purificados e inativados com $\beta$ propiolactona, representando um risco de manipulação. Portanto, a produção de proteínas virais recombinantes permitiu o desenvolvimento e métodos de diagnóstico e vacinas mais seguras. Neste trabalho foram construídos baculovírus recombinantes contendo os genes do antígeno HBsAg de HBV e de um peptídeo imunogênico derivado da glicoproteína do vírus da Raiva (Pept/G), fusionados à proteína poliederina (POLH) do baculovírus Autrographa californica multiple nucleopolyhedrovirus (AcMNPV). As proteínas recombinantes foram expressas em inseto e culturas de células na forma de agregrados protéicos cristalinos. A proteína recombinante contendo o antígeno HBSAg foi reconhecida por anticorpos anti-HBsAg em testes de imunoensaio (EIA) comerciais. A protéina recombinante contendo o Pept/G foi capaz de estimular o sistema immune de camundongos com sucesso, verificado por meio da proliferação celular in vitro. Desta forma, é possível concluir que proteínas recombinantes derivadas de vírus humanos fusionadas à protéina POLH de baculovírus são uma alternativa para a produção destes antígenos.

Palavras Chaves: HBV, HBsAg, ELISA, Virus da Raiva, BEVS. 


\section{Abstract}

Baculovirus are circular double-stranded DNA viruses that infect insects and initially used only as biological control agents for being able to eliminate insect pests associated with agriculture. In the 1970s and 1980s, its potential as a tool for the expression of heterologous proteins began to be explored. Today, baculoviruses have been used extensively to express antigens for vaccine production, diagnostics and even as potential vectors for gene therapy and DNA vaccines. Their biosafety isguaranteed by the fact that baculoviruses are not able to replicate in mammalian cells. However, they can enter these cells and present immunostimulatory abilities. In this way, numerous proteins of medical and economic importance have been expressed at high levels applying this system. Currently, there are no Brazilian-based companies available to produce HBsAg surface antigen in a large scale, and the supplies to produce both vaccines and diagnostic kits are imported from other countries. The rabies vaccine currently consists of purified and inactivated virus suspensions with $\beta$-propiolactone, representing a health risk from its manipulation. Therefore, the use of recombinant proteins from viruses allowed the development of safer diagnostic methods and vaccines. In addition, this strategy may reduce the cost of vaccine manufacturing and eventually, contribute towards disease control. In this work, we constructed two recombinant baculoviruses; one containing of sHBsAg antigen gene of HBV and second recombinant containing an immunogenic peptide derived from the rabies virus glycoprotein (Pept/G). Both were fused to the polyhedrin protein $(\mathrm{POLH})$ of the baculovirus Autrographa californica multiple nucleopolyhedrovirus (AcMNPV). Recombinant proteins were expressed in insect cells and in insects in the form of crystalline protein aggregates. The recombinant protein containing the HBSAg antigen was used in commercial immunoassay (EIA) tests and was recognized by the anti-HBsAg antibodies. A recombinant protein containing Pept/G could successfully stimulate the immune system of mice which was verified by cell proliferation in vitro. Thus, it is possible to conclude that recombinant proteins derived from human viruses fused to the baculovírus POLH protein are an alternative to produce diagnostic tests and possible subunit vaccines.

Key Words: HBV, HBsAg, ELISA, Rabies Virus, BEVS. 


\section{Capítulo 1. Introdução geral}

\section{Baculovírus - Uma Introdução}

Baculoviridae (King et al, 2012) é uma família de vírus de insetos cujo membros tem sido encontrados infectando mais de 700 espécies em todo o mundo (revisado por Miller (1997)). Embora os baculovírus possam infectar insetos das ordens Diptera e Hymenoptera, a maioria dos relatos envolve a ordem Lepdoptera. Em geral, membros desta família são altamente patogênicos e específicos; uma perfeita combinação que tornou-os úteis como agentes de controle biológico, como por exemplo, no controle da lagarta na cultura da soja (Aticarsia gemmatalis), da mariposa das maçãs e peras (Cydia pomonella), do complexo de mariposas da batata (Phthorimaea Operculella), da lagarta do cartucho do milho (Spodoptera frugiperda) e da lagarta da mandioca (Erinnyis ello) (revisado por Haase et al. (2015)). Há mais de 30 anos, os baculovírus vêm sendo usados como vetores de expressão de proteínas heterólogas, tanto em inseto como em cultura de células. Os baculovírus são utilizados também como uma importante ferramenta para aplicações biotecnológicas, como produção de vacinas, diagnóstico e terapia gênica (Ribeiro, 2015; van Oers et al, 2015).

Baculovírus possuem o formato de bastão, DNA dupla fita covalentemente circular e com tamanho variando entre 80 e $180 \mathrm{kpb}$, codificando entre 90 a 180 open reading frames (ORFs) (revisado por Rohrmann (2013)) . Durante uma típica infecção de células de insetos, os baculovírus levam a produção de dois fenótipos virais infectivos diferentes, porém geneticamente idênticos. O vírus extracelular ou brotado (ECV ou BV, do inglês, extracellular virus ou budded virus, respectivamente) que medeia a disseminação da infecção célula a célula, e o vírus derivado da oclusão (ODV, do inglês, occluded derived virus) o qual está envolvido na transmissão horizontal de inseto para inseto. O BV consiste em um único nucleocapsídeo envelopado que brota por meio da membrana das células infectadas para disseminar a infecção entre células ou via hemolinfa para outros tecidos. Em contraste, o ODV também é envelopado, mas adquire seu envelope no núcleo da célula infectada a partir de membranas derivadas da membrana interna do núcleo. Os ODVs podem conter um único nucleocapsídeo 
por envelope (SNPV, do inglês single nucleopolyhedrovirus) ou múltiplos (MNPV, do inglês multiple nucleopolyhedrovirus). Estes ODVs são embebidos em uma matriz cristalina chamada de corpo de oclusão (do inglês: occlusion body, OB) variando de 0.6 a $2 \mu \mathrm{m}$ de diâmetro, que protege os vírions no meio ambiente, fora do corpo do inseto hospedeiro (Rohrmann, 2013a). Essa matriz proteica é predominantemente e basicamente moldada por um único tipo de proteína: poliedrina ou granulina, dependendo do gênero viral (veja abaixo). Os OBs são extremamente estáveis e podem se manter por anos no meio ambiente (Thomas et al, 1972), permitindo que o vírus persista na ausência do hospedeiro por um longo período de tempo.

A transmissão horizontal ocorre por meio da ingestão de OBs pelo inseto (Figura1, fases 1 e 2). $\mathrm{O} \mathrm{pH}$ alcalino do intestino médio dissolve a matriz proteica do OB, liberando os ODVs e enzimas (Figura 1, fases 3 e 4). Estes ODVs, com o auxílio das enzimas rompem e cruzam a membrana peritrófica do lúmen intestinal, que é uma camada composta por quitina e proteína (Hegedus et al, 2009), estabelecendo assim a infecção de células epiteliais do intestino médio (Clem \& Passarelli, 2013; Miller, 1997). Depois do primeiro ciclo de replicação viral no núcleo dessas células, a produção de BVs se inicia (Figura 1, fase 5). Entretanto, vários estudos sugerem que BVs podem também ser produzidos simplesmente pelo reempacotamento de nucleocapsídeo derivado dos ODVs, antes da replicação viral. Isso ocorre quando mais de uma partícula viral entra no núcleo da célula e uma delas é enviada ao núcleo e a outra para a região basolateral da célula do intestino por transcitose. A partícula que foi endereçada ao núcleo perde seu capsídeo e o DNA viral é reconhecido pela RNA polimerase celular, que transcreve alguns genes virais. Um desses genes é o da proteína de envelope viral chamada gp64, que é sintetizada no retículo endoplasmático da célula e endereçada à membrana da região basolateral da célula. Nessa região a gp64 é reconhecida pela partícula viral que não entrou no núcleo e ocorre o brotamento dessa partícula para a hemolinfa ou célula do sistema traqueal do inseto. (Granados \& Lawler, 1981; Washburn et al, 2003a; Washburn et al, 2003b). Em sequência, BVs são transportados para outros tecidos via hemolinfa (sistema circulatório) e traquéia (sistema respiratório), disseminando a infecção para todo o inseto. Em momentos tardios de infecção, a produção de OBs ocorre no núcleo das células infectadas. Após o inseto ter sido completamente 
infectado, ocorre o rompimento das estruturas internas pelas enzimas virais, tais como quitinase e catepsina, provocando a ruptura total da carcaça (Hawtin et al, 1997), garantindo a liberação de OBs recém-formados no ambiente. Dependendo da espécie e do estágio de desenvolvimento do hospedeiro, pode ocorrer a produção de mais de $10^{10}$ OBs por larva (Entwistle P.F., 1985).
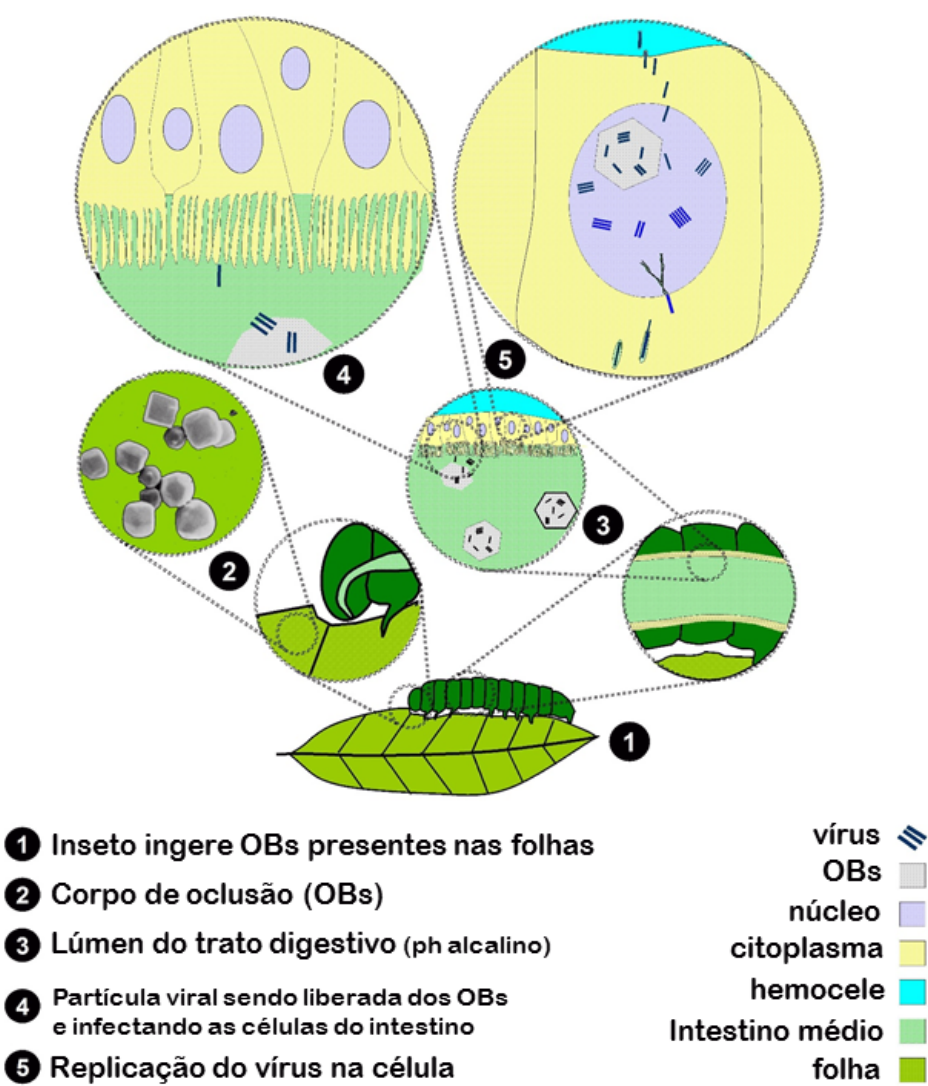

Figura 1. O ciclo de infecção de um baculovírus do grupo nucleopoliedrovírus (NPV) em um hospedeiro lepidóptero. Na fase 1 e 2 ocorre a ingestão de OBs pelo inseto; nas fases 3 e 4, devido ao $\mathrm{pH}$ alcalino do intestino médio, ocorre a dissolução da matriz proteica do OB e liberação dos ODVs e enzimas. Estes ODVs, com auxílio das enzimas, rompem e cruzam a membrana peritrófica do lúmen intestinal, estabelecendo assim, a infecção de células epiteliais do intestino médio. Na fase 5 , após ocorrer o primeiro ciclo de replicação viral no núcleo dessas células, a produção de BVs se inicia, e em sequência, BVs são transportados para outros tecidos, via hemolinfa e traqueia, espalhando a infecção para todo o inseto.

Os baculovírus compartilham uma longa história coevolutiva com seus insetos hospedeiros (Herniou et al, 2004). A análise filogenética (datação molecular) de baculovírus e nudivírus sugere que esses vírus estavam presentes na terra infectando insetos há mais de 310 milhões de anos (Theze et al, 2011), o que torna a família Baculoviridae uma das mais antigas famílias de vírus de DNA conhecidas. Isso ocorreu após a diversificação de insetos holometabólicos 
(insetos que sofrem metamorfose completa) e parece ter ocorrido no mesmo período de tempo em que ocorreu a diversificação de baculovírus (Herniou et al, 2004; Theze et al, 2011). Contudo, em menor escala, a filogenia de baculovírus não mostra exatamente a filogenia de seus hospedeiros, o que sugere que estes vírus podem ter colonizado novos hospedeiros de inseto muitas vezes durante a sua evolução (Theze et al, 2011).

Baseada na análise filogenética de proteínas virais, os baculovírus são divididos em quatro gêneros: (i) Alphabaculovirus, com vírus específicos para insetos da ordem lepidoptera, também conhecido como nucleopoliedrovírus (NPVs) de lepidópteros, (ii) Betabaculovirus, com vírus também específicos para insetos da ordem lepidoptera, também conhecidos como granulovírus (GVs) de lepidóptera, (iii) Gammabaculovirus, com vírus específicos para insetos da ordem himenoptera, também conhecidos como nucleopoliedrovírus (NPVs) de himenóptera, e (iv) Deltabaculovirus, com vírus específicos pra insetos da ordem díptera, também conhecidos como nucleopoliedrovírus (NPVs) de diptera (Jehle et al, 2006). Membros do gênero Alphabaculovirus são divididos em grupo I e grupo II NPVs (Zanotto et al, 1993). Ambos compreendem single NPVs (SNPVs), contendo um único nucleocapsídeo dentro de um ODV, e multiple NPVs (MNPVs) contendo múltiplos nucleocapsídeos dentro de um ODV (revisado por (Blissard, 1996). Estes dois fenótipos (SNPVs e MNPVs) não têm nenhum significado taxonômico e a base genética para esses fenótipos são desconhecidas. Os termos nucleopoliedrovírus (NPVs) e granulovírus (GVs) se referem aos antigos nomes dados aos dois gêneros da família Baculoviridae aceitos pelo Comitê Internacional de Taxonomia de Vírus (ICTV) entre 1993 a 2008 (revisado por Rohrmann (2013)). 


\section{Baculovírus e Aplicações}

\section{Agente de biocontrole}

Os Baculovírus têm um papel importante no controle de populações de insetos. Esses vírus têm sido amplamente aplicados nas últimas seis décadas como agentes de biocontrole contra as pragas florestais e agrícolas, devido a sua eficácia, alta especificidade e a segurança em relação aos organismos nãoalvo (Moscardi, 1999). Baculovírus são considerados seguros para os vertebrados e nenhum caso de patogenicidade para estas espécies foi relatado (Bocca et al, 2013; Krieg et al, 1980). A sua especificidade de hospedeiro é geralmente muito estrita e muitas vezes limitada a uma única espécie de insetos. O interesse em baculovírus como agentes de biocontrole está crescendo, devido ao desenvolvimento de resistência dos insetos a inseticidas químicos (Moulton et al, 2002). No entanto, existem vários inconvenientes que limitam a utilização de baculovírus, como por exemplo sua baixa velocidade de ação em relação a produtos químicos na mortalidade dos insentos-praga e as limitações em sua produção em larga escala. A velocidade de ação dos baculovírus é relativamente lenta (dias ou semanas) comparada com muitos inseticidas químicos (<dias). Esses fatores fizeram a engenharia genética de baculovírus um importante campo de investigação nos últimos 25 anos. Reduzir o tempo que leva para o baculovírus estabelecer a infecção e matar o seu hospedeiro é um dos principais focos, como por exemplo a utilização deste vírus para a expressão de genes heterólogos, tais como toxinas de inseto-específicas derivada de escorpião (Androctonus australis) e aranha (Brachypelma Albiceps) (Ardisson-Araújo et al, 2013a; Maeda et al, 1991); deleção e inserção de genes virais relacionados com a virulência do baculovírus(Oreilly \& Miller, 1991; Ribeiro, 2001).

\section{Sistema de expressão heteróloga}

A regulação da expressão gênica em baculovírus é baseada em estudos com o vírus Autographa californica multiple nucleopolyhedrovirus (AcMNPV) e células de Spodoptera frugiperda e pode ser dividida em duas fases principais: fase precoce (early) e fase tardia (late). Essas fases podem ser subdivididas em 
fase precoce imediata (immediately early), cujos genes são expressos nas primeiras horas de infecção, e fase muito tardia (very late), que representa os genes que são expressos após 18-24 horas de infecção (Rohrmann, 2013a). A fase precoce imediata se inicia a partir de aproximadamente 20 minutos até 8 horas pós-infecção e corresponde basicamente à síntese de fatores de transcrição, bem como as proteínas pertencentes à maquinaria de replicação viral (Friesen, 1997). Quando o DNA viral começa a ser replicado, inicia-se a fase tardia. Nessa fase há intensa produção de proteínas responsáveis pela construção de partículas virais extracelulares (BV). Essa fase se estende até 24 h.p.i. (horas pós-infecção) (Lu \& Miller, 1997). Na última fase da infecção, a poliedrina $(\mathrm{POLH})$, uma proteína de aproximadamente $30 \mathrm{kDa}$, é produzida em grande quantidade (Rohrmann, 1986). A poliedrina, codificada pelo gene polh, é a principal constituinte dos corpos de oclusão viral (OBs), que ao serem ingeridos pelo inseto são dissolvidos no intestino médio devido ao pH alcalino (Funk et al, 1997). Essa proteína compreende mais de $95 \%$ de todas as proteínas dos OBs (Jarvis, 1997). Entretanto, o gene polh não é essencial para a replicação viral em cultura de células. Por isso, a região do gene da poliedrina e seu promotor são usados para a construção de baculovírus recombinantes para expressão de proteínas heterólogas (Rohrmann, 1986).

Os Baculovírus tem sido amplamente aplicados em biotecnologia como vetores para a produção de proteínas recombinantes em células de insetos devido ao alto nível de expressão de genes heterólogos usando promotores de genes baculovirais envolvidos no processo de oclusão (van Oers, 2011). A principal vantagem da utilização de células de inseto quando comparadas às células bacterianas e de leveduras é que elas proporcionam modificações póstraducionais (glicosilação e fosforilação, por exemplo) mais próximas às que ocorrem em células de mamíferos, tornando-as adequadas para a produção de vacinas, potêncial uso como vetor de terapia gênica, e a segurança inerente do processo de produção. A maioria dos sistemas de expressão em células de inseto usando baculovírus, disponíveis comercialmente, baseiam-se na espécie tipo, AcMNPV. Os genes envolvidos no processo de formação de OBs e transcritos em fases tardias da infecção (poliedrina e p10) têm uma atividade transcricional extremamente elevada (cerca de $25 \%$ de mRNA total de células infectadas) nesse período e não são essenciais para a produção de BV fazendo 
com que esses promotores sejam escolhidos para comandar a transcrição dos genes heterólogos em células de inseto (Condreay \& Kost, 2007). Como os genes poliedrina (polh) e p10 não são essenciais para replicação viral em células de inseto, eles podem ser substituídos pelos genes heterólogos. No entanto, existem outros vetores de expressão disponíveis que utilizam promotores que são menos ativos transcricionalmente ou estão ativos no início do processo de infecção (Condreay \& Kost, 2007; Ribeiro, 2015).

O primeiro trabalho que relatou o uso de baculovírus como vetor para expressão de proteínas heterólogas, do inglês baculovirus expression vector system (BEVS) foi descrito por Smith et al. (1983), com a expressão da proteína beta interferon em células de inseto infectadas por um baculovírus geneticamente modificado. Para tanto, foi utilizado o promotor da polh do AcMNPV para comandar a expressão do gene heterólogo.

Nos últimos anos, a utilização de BEVS vêm sendo aprimorada, como a produção de linhagens de células de inseto transgênicas capazes de modificar proteínas com alterações pós-traducionais de células de mamíferos, como por exemplo a glicosilação com resíduos de ácido siálico. Os baculovírus também são usados como vetores de entrega gênica em células de mamíferos, e apresentadores de antígenos (Jarvis, 2009; Kost et al, 2005). Além disso, esse sistema resultou na produção de vacinas contra doenças virais baseadas em virus-like particles (VLP) Cervarix ${ }^{\circledR}$ (Papilomavirus humano) e Ingelvac ${ }^{\circledR}$ Circoflex ${ }^{\mathrm{TM}}$ (circovirus suíno) (Mena \& Kamen, 2011).

O método mais usado para a construção de baculovírus recombinantes hoje em dia é o sistema comercial Bac-to-Bac (Invitrogen). Esta estratégia baseia-se na transposição sítio específica em cassete de expressão no genoma de um baculovírus (bacmídeo) propagado em E. coli (Luckow et al, 1993). Este cassete contém uma origem de replicação mini-F para baixo número de cópias, um marcador de resistência à canamicina, e segmento de DNA que codifica o peptídeo LacZa, no qual o sitio para a transposição bacteriana mini-att $\operatorname{Tn} 7$ foi inserido no locus do gene polh (sitio não interrompe a ORF do peptídeo) foi inserido no genoma do baculovírus.

O sistema Bac-to-Bac utiliza das vantagens das propriedades de transposição específica Tn7 para acelerar o processo de geração do bacmídeo recombinante. Para isso, a reação de transposição requer dois componentes: a) 
um vetor de transferência ( $p$ FastBac ${ }^{\mathrm{TM}}$ ) em que o gene ( $\mathrm{s}$ ) de interesse vai ser clonado. Dependendo do vector $\mathrm{pFastBac}{ }^{\mathrm{TM}}$ selecionado, a expressão do gene (s) de interesse é controlada pelo promotor da poliedrina de AcMNPV ou promotor do gene $p 10$. Este cassete de expressão é flanqueado pelo sitio Tn7R e TN7L, além de um gene de resistência à gentamicina e um sinal de poliadenilação (SV40) para formar um mini-Tn7; b) uma linhagem de E. coli $\left(\mathrm{DH} 10 \mathrm{Bac}^{\mathrm{T}}{ }^{\mathrm{T}}\right)$ que é utilizada para receber o vector pFastBac ${ }^{\mathrm{T}}{ }^{\mathrm{M}}$. As células DH10Bac TM contém o genoma do baculovírus AcMNPV (bacmídeo) com um sitio de destino de transposição mini-att Tn7 e um plasmídeo auxiliar (helper). Uma vez que o plasmídeo de expressão pFastBac ${ }^{\mathrm{TM}}$ é transformado em células DH10Bac ${ }^{\mathrm{TM}}$, a transposição ocorre entre o elemento mini-Tn7 no vetor pFastBac ${ }^{\mathrm{T} M}$ e o sitio mini-att $\mathrm{Tn} 7$ alvo no bacmídeo para gerar um bacmídeo recombinante. Esta reação de transposição ocorre na presença do plasmídeo auxiliar, que codifica uma transposase e confere resistência à tetraciclina. $O$ plasmídeo auxiliar fornece a função de transposição $\mathrm{Tn} 7 \mathrm{em}$ trans no transposon $\mathrm{Tn} 7$ durante a transposição (Barry, 1988).

Após a transposição, o bacmídeo propaga-se em E. coli DH10Bac тM como um grande plasmídeo que confere resistência a canamicina. Dessa forma a bactéria pode ser cultivada para posterior extração de DNA e subsequente transfecção de células de inseto. Assim, serão geradas as partículas infecciosas de baculovírus recombinantes (Luckow et al, 1993; Yao et al, 2007) (Figura 2). 


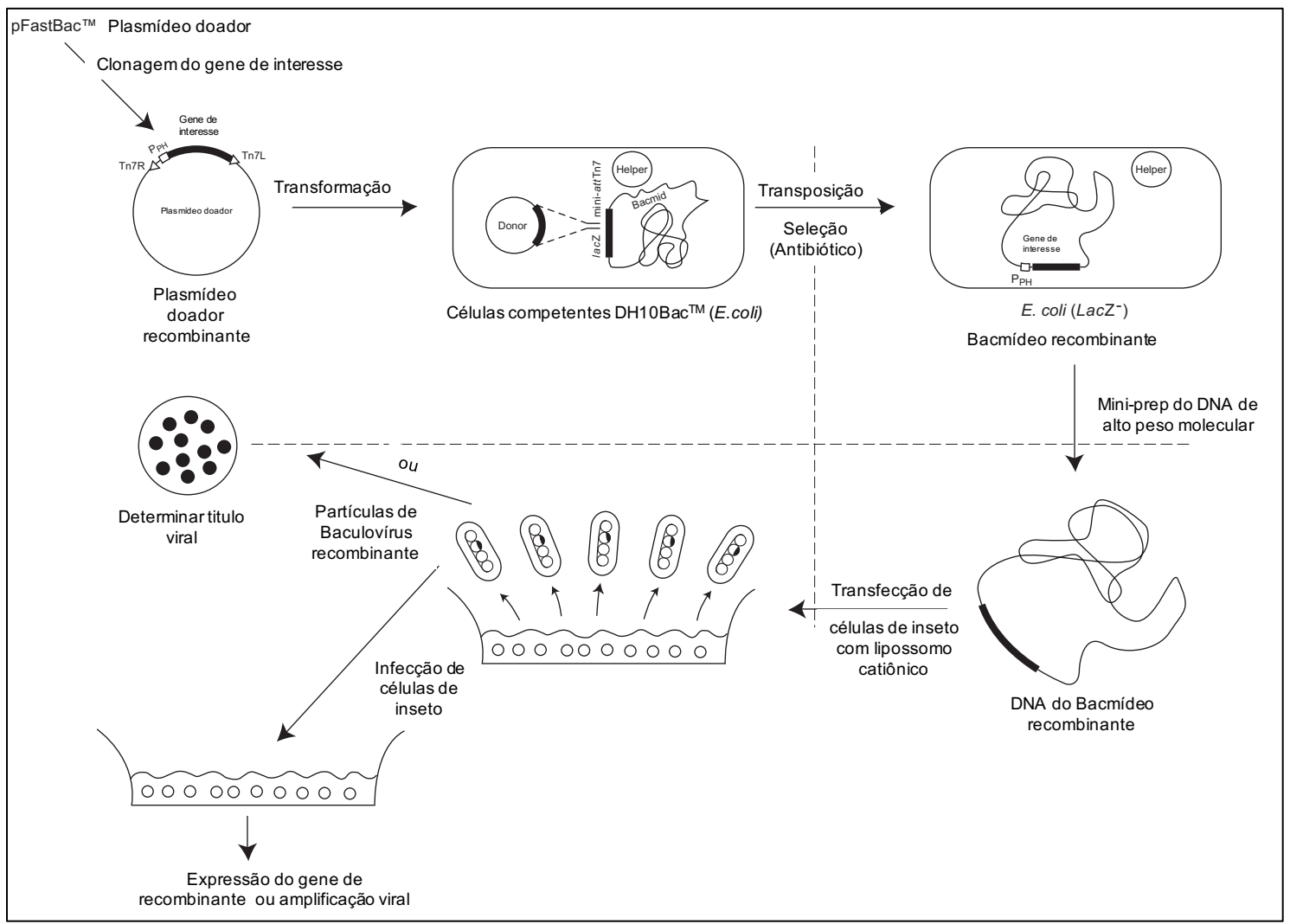

Figura 2. Esquema mostrando o sistema Bac-to-Bac da Invitrogem. O gene de interesse clonado no vetor de transferência é transformado em células de $E$. coli (DH10Bac, Invitrogen) que possui o genoma do vírus AcMNPV na forma de um grande plasmídeo (denominado de bacmideo). $O$ gene de interesse está flanqueado por regiões de transposição do transposon TN7 (regiões TN7L e TN7R). O bacmideo possui o sítio alvo de inserção do transposon TN7, onde será inserido o gene de interesse sob o comando do promotor da polh e o gene do antibiótico gentamicina. Essa transposição é feita com a ajuda de um outro plasmídeo ('helper'), presente nas células DH10Bac que codifica para a enzima transposase. A transposição é confirmada através da seleção por antibióticos e a $\alpha$ complementação da $\beta$-galactosidade (ver texto). Depois de uma lise alcalina em pequena escala (miniprep) para obtenção do DNA, é realizado a transfecção de células de inseto com a ajuda de lipossomos catiônicos, onde o DNA do baculovírus por si só infecta as células de inseto O sobrenadante da transfecção contendo os vírus no fenótipo BV é utilizado para amplificação viral através da infecção de células de inseto ou para determinação do título viral. Fonte: Manual Bac-to-bac. 


\section{Capítulo 2. Hepatite B}

\section{O vírus da hepatite $B$ (HBV)}

\section{Introdução}

O vírus da hepatite $B$ (HBV) é um membro da família de vírus chamada Hepadnaviridae. Apresenta DNA envelopado, e se caracteriza pela capacidade de infectar as células hepáticas. Esse vírus infecta mamíferos e se replica nos hepatócitos por transcrição reversa, a partir de um RNA pré-genômico (El Khouri \& Santos, 2004; Lee, 1997; Seeger \& Mason, 2000).

A partícula infecciosa do HBV (vírion) é denominada de partícula de Dane (Figura 3). Esta partícula apresenta-se de forma esférica com diâmetro de aproximadamente $42 \mathrm{~nm}$, a qual possui estrutura complexa com envoltório externo lipoproteico e interno. O envoltório externo é formado pela proteína da membrana viral HBs ( $s$ de surface) que constitui o antígeno de superfície do HBV (HBsAg). Internamente ao envelope viral tem-se a proteína $\mathrm{HBc}$ (c de core) que possui 30 a $34 \mathrm{~nm}$ de diâmetro, o antígeno do core do vírus ( $\mathrm{HBcAg}$ ), o antígeno "e" (HBeAg), o genoma viral e as enzimas DNA-polimerase e transcriptase reversa (Zhang \& Cao, 2011) (Figura 3).

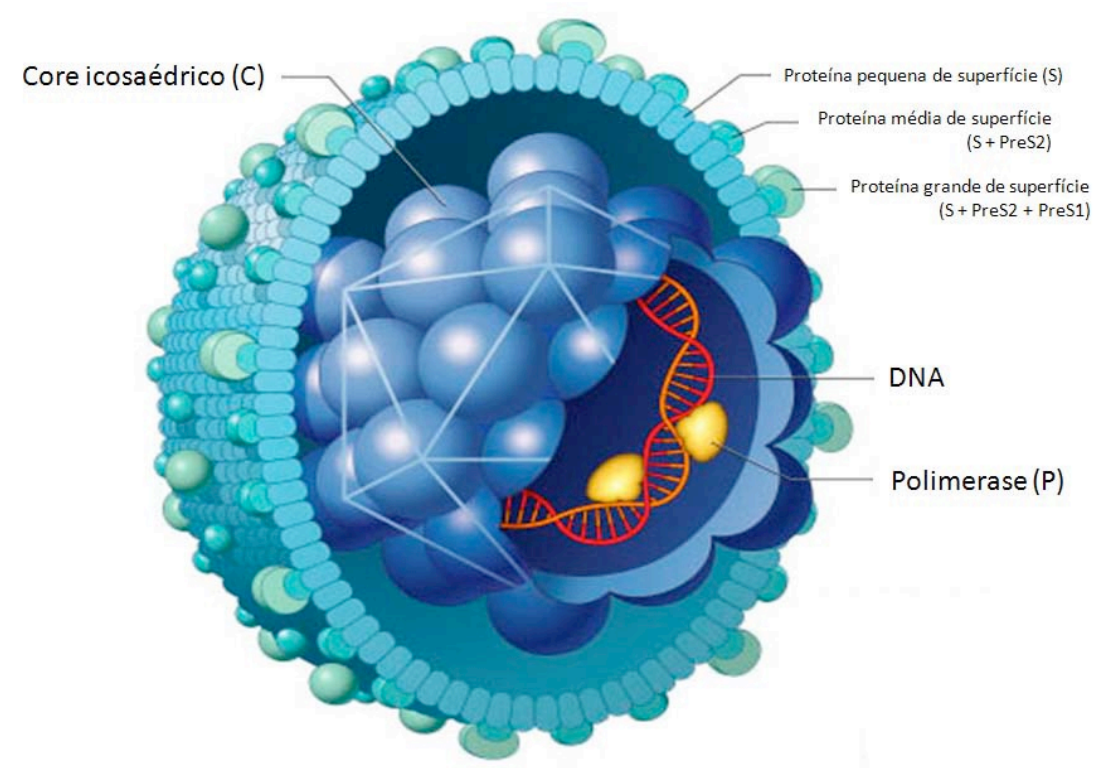

Figura 3. Esquema do HBV. No esquema estão sendo mostrados o nucleocapsídeo icosaédrico constituído por proteínas do core (C). O vírus é revestido por um envelope que contém três tipos de proteínas relacionadas entre si, as glicoproteínas S, Pré S1e S2 de membrana que formam o antígeno de superfície mais imunogênico do HBV, O HBsAg. Fonte: http://www.hepcentro.com.br/images/HBV.gif 
O HBV apresenta um material genético compacto; uma molécula de DNA circular de fita dupla incompleta, com o tamanho de 3,2 kb (Hatzakis et al, 2006). O seu genoma está organizado em duas cadeias de polaridades invertidas, uma menor e incompleta de polaridade positiva, e outra maior e completa de polaridade negativa (Beck \& Nassal, 2007; Bruss, 2004), apresentando quatro ORFs (Seeger \& Mason, 2000) designadas de: a) Pré S1IPré-S2IS com a função de codificação das proteínas que formam o HBsAg e as proteínas $L$ (large), $M$ (middle) e S (small) (Tian et al, 2007); b) Pré-ClC que sintetiza as proteínas do HBcAg e HBeAg (Ganem \& Prince, 2004); c) P, responsável pela síntese da DNA polimerase (Lee, 1997) e d) X, com a função de síntese da proteína X, que está provavelmente envolvida na replicação viral e no surgimento do Carcinoma Hepatocelular (Grob, 1998; Liang, 2000) (Figura 4).

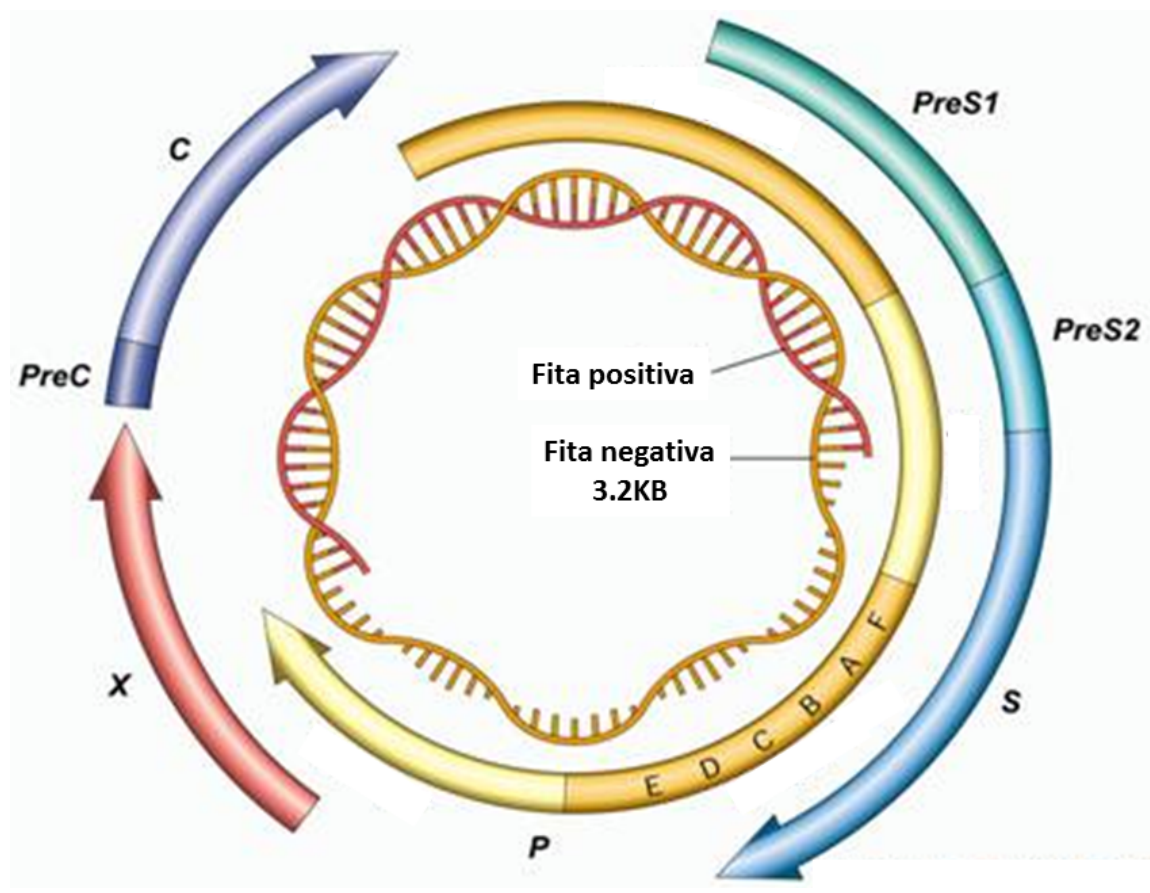

Figura 4. Representação esquemática da organização do genoma HBV. O círculo interno representa o DNA viral, indicado por duas fitas, uma contínua (amarela) de polaridade negativa e de tamanho $3,2 \mathrm{~kb}$, e uma descontínua (vermelha) de polaridade positiva. Pode ser observado também as regiões de fase aberta de leitura (ORF): pré- $S / S$ (contém as regiões pré $S 1$, S2 e S), pré-C/C, P e X. Fonte: http://www.drthuthuy.com/images/genotype02.jpg (modificado).

Na década de 80, o vírus da hepatite $B$ foi classificado em subtipos de acordo com mudanças específicas de aminoácidos na proteína $\mathrm{S}$, sendo associado com as regiões geográficas de ocorrência. Em 2000, através do sequenciamento da porção $S$ do genoma viral, a classificação resultou em oito grupos genômicos $(\mathrm{A}$ a $\mathrm{H})$, que se mantém até os dias de hoje. Na América do Sul é frequentemente encontrado o grupo $\mathrm{F}$ (Arauz-Ruiz et al, 2002). 


\section{Ciclo de Replicação viral}

O ciclo de replicação do VHB se inicia quando o vírus se liga à membrana da célula hospedeira mediado pelas proteínas de envelope. Estudos demonstram que o VHB se liga por meio do domínio Pré-S1 da proteína de envelope à um receptor na membrana plasmática de hepatócitos humanos. Posteriormente, a membrana viral é fundida com a membrana celular, liberando o genoma no interior das células. A polimerase viral converte o dsDNA (DNA de fita dupla) parcial em forma circular dupla covalentemente fechada (cccDNA). Este DNA é transcrito pela RNA Polimerase-II do hospedeiro, e o DNA resultante serve como molde para a propagação de RNA pré-genômico e RNA subgenômico (Beck \& Nassal, 2007). O RNA pré-genômico é bifuncional, servindo tanto como molde para a síntese de DNA viral como mRNA para a tradução do pré-C, C e P. Os RNAs sub-genômicos funcionam exclusivamente para a tradução das proteínas de envelope e da proteína X (Ganem \& Prince, 2004; Hatzakis et al, 2006; Neurath et al, 1986).

\section{Transmissão}

A transmissão do HBV ocorre principalmente pela via sanguínea como por exemplo exposição parenteral, exposição percutânea (lesões provocadas por instrumentos perfurantes e cortantes), sexual e vertical (Rizzetto \& Ciancio, 2008; Shapiro, 1993). O sangue é considerado o fluido corpóreo com maior incidência de transmissão. No entanto, a transmissão percutânea pode ocorrer, devido ao vírus ser bastante resistente à agentes físicos, como o calor e ser estável à temperatura ambiente por mais de sete dias. Além disso, a sua inoculação indireta também pode ocorrer por meio do compartilhamento de escovas de dente, lâminas de barbear ou de depilar, canudo e cachimbo para uso de drogas, entre outros (Locarnini, 2003; Rapparini et al, 2000).

Apenas uma partícula do HBV é suficiente para infectar o ser humano (Fonseca, 2007), sendo o HBV considerado dez vezes mais infectante que o HCV e 100 vezes mais que o HIV (Komatsu et al, 2010). Estudos revelam que o 
sangue e os outros fluidos orgânicos de um portador do HBV podem ser infectantes duas a três semanas anteriormente do surgimento dos primeiros sinais da hepatite $B$, mantendo-se assim durante a fase aguda e crônica da doença (BRASIL, 2008a; Komatsu et al, 2010).

O HBV pode apresentar se em níveis elevados no sangue e em concentrações inferiores nos outros fluidos orgânicos (Hollinger \& Liang, 2001; Margolis et al, 1991), tais como saliva (Davison et al, 1987; Jenison et al, 1987), sêmen (Zhang et al, 1994), secreção vaginal (Darani \& Gerber, 1974; Yue et al, 2004), urina (Hourani et al, 1978; Irwin et al, 1975; Tripatzis, 1972), colostro ou leite materno(Lu et al, 2008) e fezes (Davison et al, 1987; Villarejos et al, 1974). Contudo, há a necessidade de uma investigação mais detalhada com relação à transmissão do HBV por meio do aleitamento materno (Zheng et al, 2011).

\section{Diagnóstico}

O diagnóstico da infecção pelo vírus da hepatite $B$ é realizado por meio de exames clínicos e laboratoriais. Dentre os exames laboratoriais, as dosagens bioquímicas das aminotransferases (níveis de alanina aminotransferase-ALT ou transaminase glutâmico pirúvica (TGP) e de aspartato aminotransferase-AST ou transaminase glutâmico-oxalacética (TGO) são de grande importância, não só para o diagnóstico como também para acompanhamento clínico e tratamento da doença. Entretanto, a detecção dos marcadores sorológicos do HBV é uma importante ferramenta para a confirmação da infecção (Nascimento et al, 2012).

Testes sorológicos foram desenvolvidos para a identificação dos antígenos virais (HBsAg e HBeAg) e anticorpos (anti-HBs, anti-HBe, anti-HBc total e anti-HBc IgM) (Lai et al, 2003; Peter, 1997). Mais recentemente, testes de biologia molecular para detecção do DNA viral, como a PCR em tempo real, permitem a pesquisa qualitativa e quantitativa do genoma viral (Moreira et al, 2010). Os testes mais utilizados no diagnóstico sorológico são os ensaios imunoenzimáticos (Pawlotsky et al, 2008).

Os achados sorológicos variam nas fases de evolução da doença, e a 
dinâmica da presença dos marcadores reflete a replicação do vírus e a resposta imune dos infectados (Hoofnagle, 1983). Em indivíduos recentemente infectados, o antígeno de superfície (HBsAg) é o primeiro marcador sorológico a surgir, sendo detectável durante o período de incubação, cerca de duas a sete semanas antes dos sintomas, persistindo por um período de até 180 dias, desaparecendo cerca de quatro a cinco meses após a exposição (da Silva et al, 2012).

Na recuperação da infecção, os títulos de HBsAg desaparecem após seis meses, e emerge o anticorpo específico (anti-HBs) que se mantém detectável no soro por toda a vida do paciente, funcionando como o anticorpo protetor da hepatite $B$ (marcador de imunidade). A positividade para 0 anti-HBs e a negatividade de todos os outros marcadores correspondem à resposta imune à vacina contra o HBV (Liang, 2000; Okanoue \& Minami, 2006; Van Der Eijk et al, 2006). No período denominado de "janela imunológica", compreendido entre a clarificação do HBsAg e o surgimento do anti-HBs, ambos permanecem indetectáveis, somente o anti-HBc está presente (Gonçales Júnior, 2002).

O antígeno $\mathrm{HBc}(\mathrm{HBcAg})$, proteína estrutural do capsídeo viral, presente nos hepatócitos infectados, não é comumente detectado no soro, é um potente imunógeno que induz a formação de anti-HBc e aparece logo após o surgimento do HBsAg (Custer et al, 2004). O anti-HBc total é detectável em pacientes que foram expostos ao HBV, não é um anticorpo protetor, e representa as frações IgM e IgG que são importantes na distinção da infecção atual e passada pelo vírus: a) o anti- $\mathrm{HBc}$ IgM é marcador de infecção recente, o único que define a etiologia da infecção como hepatite $B$ aguda e é o primeiro anticorpo a ser detectado cerca de um mês após o aparecimento do HBsAg, e é detectável por cerca de seis meses; b) o anti- HBc IgG é um marcador de longa duração, presente nas infecções agudas, crônicas ou na infecção antiga pelo vírus $B$ já curada, representa contato prévio com o HBV e memória imunológica (Hollinger, 2008). O anti-HBc total é considerado um marcador de infecção pregressa do HBV e pode persistir com anti- HBs em pacientes com quadros de infecção passada com consequente imunidade ao HBV (Gonçales \& Cavalheiro, 2006). 
$\mathrm{Na}$ hepatite crônica, ocorre a persistência de positividade do HBsAg, associada à detecção do antígeno $\mathrm{HBeAg}$ que está relacionado à intensa replicação viral e à infecciosidade, e sua presença usualmente se associa à positividade do DNA do HBV, no soro, com alto risco de transmissão da infecção. Pode persistir por dez semanas na fase aguda e, em pacientes crônicos, está associado a um mau prognóstico, refletindo a persistência da infecção viral e maior taxa de transmissão (El Khouri \& Santos, 2004). O desaparecimento do $\mathrm{HBeAg}$ e o surgimento do anti-HBe sugerem diminuição ou ausência da replicação viral e se associam à negativação do HBV-DNA no soro e à normalização das aminotransferases (Hadziyannis \& Vassilopoulos, 2001) (Figura 5)

Afirma-se que a infecção crônica é resolvida quando o paciente apresenta história prévia de hepatite crônica, positividade sorológica para anti-HBc total, HBsAg negativo, níveis normais de ALT e DNA-HBV sérico indetectável, com ou sem soroconversão para anti-HBs (Fonseca, 2007; Paraná et al, 2006).

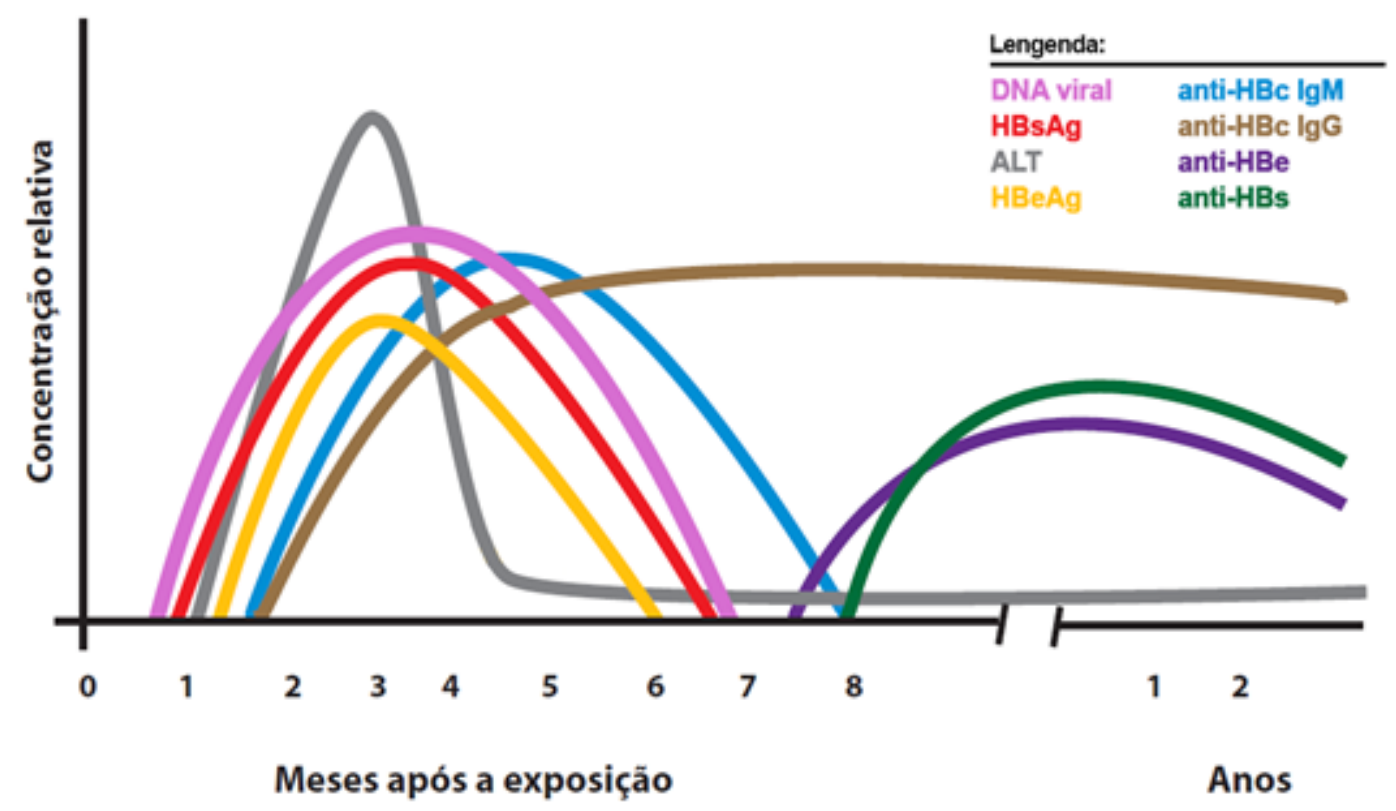

Figura 5. Marcadores sorológicos e molecular da infecção pelo HBV. O primeiro marcador a ser detectado é o DNA viral. Dentre os marcadores sorológicos, o HBsAg é o primeiro que circula, aparecendo aproximadamente um mês após a exposição e desaparecendo cerca de 6 meses para as infecções com cura. Após o HBsAg, aparece o anti-HBc IgM. O anti-HBc IgG aparece em seguida ao anti-HBc IgM e pode ser detectável por muitos anos após a doença. Neste mesmo período agudo aparece o $\mathrm{HBeAg}$, que indica replicação viral. Nesta fase inicial da infecção também estão aumentados os níveis de alanina aminotransferase (ALT), enzima que indica lesão no fígado. Após o desaparecimento dos antígenos, surgem os anticorpos, representado pelo aparecimento do anti-HBe e o anti-HBs. http://www.saude.gov.br/bvs. 


\section{Tratamento}

O tratamento para HBV tem como objetivo prevenir o desenvolvimento da cirrose hepática e/ou Carcinoma Hepatocelular $(\mathrm{CHC})$, por meio da antecipação da soroconversão do $\mathrm{HBeAg-positivo} \mathrm{em} \mathrm{anti-HBe.} \mathrm{Diante} \mathrm{disso,} \mathrm{o} \mathrm{tratamento}$ consiste em dois tipos de agentes terapêuticos: Interferon e os análogos de nucleosídeos ou de nucleotídeos (AN). Os interferons compreendem o interferon convencional, de difícil emprego no tratamento da HBV devido à necessidade de altas dosagens diárias, e o interferon peguilado. Os AN compreendem aos medicamentos lamivudina (LVD), o adefovir (ADV) e o entecavir (ETV), que são inibidores de replicação viral, porém o seu uso por longo tempo pode selecionar cepas resistentes.

Varios avanços ocorreram nas últimas décadas no que se refere à prevenção e ao controle das hepatites virais, tais como: melhoras na identificação dos agentes virais, o desenvolvimento de testes laboratoriais específicos, maior eficácia no rastreamento dos indivíduos infectados e o surgimento de vacinas protetoras (Roberto, 2007).

A vacina contra o HBV é a forma mais eficaz para a prevenção da hepatite $B$ e tem proporcionado grande avanço no controle desta enfermidade. (Carvalho \& Araújo, 2008). A primeira vacina disponível para prevenir hepatite viral foi contra o HBV, desenvolvida no início dos anos 1980 e feita com plasma humano. Posteriormente, foi substituída por vacinas produzidas por meio da técnica do DNA recombinante. $O$ antígeno utilizado nas vacinas disponíveis atualmente é um HBsAg recombinante produzido em fungo. Esta proteína recombinante é purificada e adsorvida em hidróxido de alumínio, sendo que o produto final contém mais de $95 \%$ de proteína $\mathrm{HBsAg}$, menos de $5 \%$ de proteínas derivadas do fungo e nenhum DNA do fungo detectável na vacina (Ferreira \& Silveira, 2004). 


\section{Justificativa}

Os baculovírus têm sido utilizados amplamente como vetores de expressão de genes heterólogos em células de inseto e extensivamente pela área médica nos últimos anos. Deste modo, inúmeras proteínas de importância médica e econômica foram expressas em níveis elevados aplicando esse sistema (Miller, 1997; van Oers et al, 2015).

A produção do antígeno de superfície HBsAg fusionado à proteína poliedrina do baculovírus é uma estratégia promissora para expressão e purificação destas proteínas em larga escala para fins biomédicos.

O HBsAg tem um papel fundamental no diagnóstico e prevenção da hepatite B. Este antígeno é o marcador sorológico indicativo de infecção presente pelo HBV, bem como, o único componente da vacina contra o HBV.

Atualmente, não existem indústrias ou empresas nacionais disponíveis para a produção escalonável do HBsAg. Perante isso, os insumos são importados tanto para fins vacinais como para o diagnóstico. Assim, a expressão da porção 'small' do antígeno HBsAg (sHBsAg) em células de inseto proposto por este projeto poderá ajudar no desenvolvimento de kits diagnósticos para a Hepatite B no país, e ser um interessante passo para se pensar uma alternativa de produção de antígeno vacinal nacional.

Araújo (2011), trabalhando com o HBV, obteve sucesso na construção de um baculovírus recombinante expressando a sHBsAg fusionada á região 5 ' do gene da poliedrina do baculovírus AcMNPV $(\mathrm{AcPH})$, porém não obteve o sucesso na fusão à região 3' do gene da poliedrina. A análise da expressão da proteína recombinante em células de inseto infectadas revelou que a proteína recombinante sHBsAgAcPH foi produzida tanto in vitro (células de inseto em cultura) como in vivo (larvas de Spodoptera frugiperda). Os testes utilizando extratos de células de inseto com o vírus recombinante contendo a proteína sHBsAgAcPH e corpos de oclusão purificados em gradiente de sacarose a partir de cadáveres de insetos, foram capazes de ser reconhecidos em kits de diagnósticos no Laboratório Central de Saúde Pública do Distrito Federal (LACEN-DF). Entretanto, esses corpos de oclusão não possuíam uma forma definida e sua purificação livre de contaminantes não foi possível. Desta forma, 
a construção de vetores para formação de novos corpos de oclusão com forma parecida com a do vírus selvagem seria importante para melhorar sua purificação e para posterior uso nos testes de imuno-ensaio (EIA), realizados no LACENDF.

Diante desta abordagem testada, além da fusão na região 5 ' do gene da poliedrina para o sHBsAg foram pensadas novas estratégias para melhorar a produção e purificação dos insumos.

Assim, neste trabalho novas estratégias de fusão dos genes sHBsAg e polh, bem como a expressão de uma cópia extra do gene polh do baculovírus AcMNPV foram testadas. Esta segunda estratégia teve como objetivo permitir que os corpos de oclusão apresentem o formato próximo do selvagem, além disso, tornem-se mais fáceis de serem purificados por centrifugação em gradiente de sacarose com redução de contaminantes. A facilidade de produção, isolamento de poliedros recombinantes contendo proteínas de interesse e a natureza estável dos poliedros sugerem que essa abordagem poderá ser uma excelente ferramenta alternativa para vacinação e uso em diagnóstico de vertebrados.

Outra aplicação para estas construções será a utilização como imunomoduladores. Os corpos de oclusão de baculovírus recombinantes, quando em contato com células de mamíferos in vivo, são capazes de ativar a resposta imunológica, de maneira antígeno específica (Bocca et al, 2013).

\section{Objetivos}

\section{Objetivo geral}

O objetivo geral deste estudo foi produzir novos antígenos derivados do HBV em insetos e culturas de células e avaliá-los em testes diagnósticos comumente utilizados nos laboratórios de análises clínicas.

\section{Objetivos específicos}


* Construir baculovírus recombinantes contendo o gene sHBsAg fusionado ao gene da poliedrina do baculovírus AcMNPV na região 3' e outros dois vetores (fusionado em ambos os lados da poliedrina) com mais uma cópia do gene da poliedrina selvagem visando a produção de um corpo de oclusão mais próximo dos produzidos pelo vírus selvagem.

Analisar a expressão das proteínas recombinantes fusionadas (sHBsAg) em insetos e culturas de células de inseto;

Padronizar um método de purificação de corpos de oclusão contendo as proteínas heterólogas a partir de cadáveres de insetos infectados pelo vírus recombinantes;

* Testar os antígenos produzidos em testes diagnósticos comumente utilizados nos laboratórios de análises clínicas, que consistem nos testes imunoenzimáticos (ELISA).

\section{Materiais e Métodos}

\section{Vírus e Células}

Os vírus AcMNPV e o baculovírus recombinante vAc-6xHis-sHBsAg$\mathrm{AcPH}$, contendo o gene sHBSAg fusionado à região 5' do gene polh de AcMNPV (Araujo, 2011), e os baculovírus recombinantes construídos nesse trabalho, todos derivados do bacmídeo bMON14272 (Bac-to-Bac "Baculovirus Expression System", Invitrogen) foram utilizados. Os vírus foram propagados em cultura de células Trichoplusia ni (BTI-Tn5B1-4 ou Tn5B) (Granados et al, 1994) e/ou larvas de Spodoptera frugiperda, no terceiro instar. Essas células foram mantidas em meio TC-100 (Gibco-BRL) com $10 \%$ de soro fetal bovino a $28^{\circ} \mathrm{C}$ e as larvas a $25^{\circ} \mathrm{C}$, com dieta artificial (Greene et al, 1976).

Células de Escherichia coli DH10ß (Invitrogen) foram utilizadas como hospedeiras para maioria dos plasmídeos utilizados no presente trabalho. No entanto, experimentos envolvendo Bac-to-Bac "Baculovirus Expression System" (Invitrogen), foram utilizadas células Escherichia coli DH10Bac (Invitrogen). 


\section{Obtenção e clonagem do antígeno sHBsAg}

Foram inseridos, por meio de iniciadores específicos, sítios para a enzima de restrição Nco I em ambas as extremidades do gene, de modo a permitir a fusão do epítopo do HBV na região 3' da poliedrina. As reações de PCR foram realizadas em termociclador marca Switft $\operatorname{Max}\left(\mathrm{ESCO}^{\circledR}\right)$, analisadas por eletroforese em gel da agarose (Joseph \& David, 2001) e fotografadas em um fotodocumentador (Alfa Innotec). Os fragmentos observados foram cortados do gel com auxílio de uma lâmina e purificados utilizando-se 'GFX PCR DNA and Gel Band Purification kit' (GE Healthcare). Os fragmentos purificados foram clonados no vetor $\mathrm{pGem}^{\circledR}-\mathrm{T}$ easy (Promega) de acordo com instruções do fabricante. Posteriormente, os plasmídeos obtidos foram sequenciados (Macrogen Inc., Coreia do Sul) usando iniciadores T7 e SP6 que se paream em regiões presentes no plasmídeo comercial usado.

\section{Clonagem do gene sHBsAg na região 3' do gene polh do AcMNPV e em um vetor contendo um gene polh extra}

Um plasmídeo doador, previamente construído, foi utilizado para clonagem do gene sHBsAg. Esse plasmídeo é derivado do vetor comercial pFastBac1® (Invitrogen), que permite fusão de genes de interesse à região 3' (pFastAcPH3) da poliedrina do AcMNPV (Araujo, 2011). Este vetor apresenta o gene da poliedrina com o códon de terminação natural deletado, um sítio de restrição para Nco I e uma cauda de hexa-histidina em fase, ambos na região carboxi-terminal da proteína (Figura 7-a). O plasmídeo pGem-sHBsAg contendo o gene de interesse foi digerido com Nco I, submetido a reação eletroforética e a banda liberada foi purificada e utilizada para clonagem no plasmídeo doador pFastAcPH3 previamente digeridos com a mesma enzima e defosforilado. $O$ plasmídeo resultante foi confirmado por PCR com iniciadores específicos, por digestão e sequenciamento (Macrogen, Coreia do Sul). Depois da construção do vetor contendo o gene sHBsAg fusionado ao gene da poliedrina do AcMNPV, o gene quimera foi amplificado utilizando oligonucleotídeos específicos e clonado 
no vetor de clonagem pGEM®-T easy como descrito acima. O plasmídeo foi amplificado em E. Coli DH10ß (Invitrogen) e o fragmento contendo o gene quimera removido do plasmídeo utilizando enzimas de restrição específica e clonados no vetor pFastBac1/Accl-PSX (Ardisson-Araújo et al, 2013b). O vetor pFastBac1/Accl-PSX é derivado do vetor comercial pFastBac1 e possui uma cópia do gene da poliedrina e um sítio de multiclonagem para clonagem de genes heterólogos sob o comando do promotor híbrido pSyn/pXIV (Figura 7-b) (Wang et al, 1999).

\section{a}

PFB1-PH3

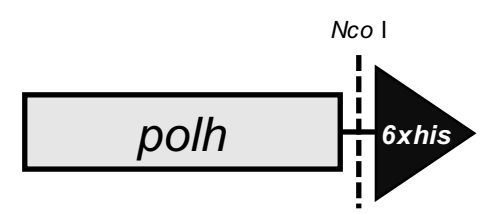

b

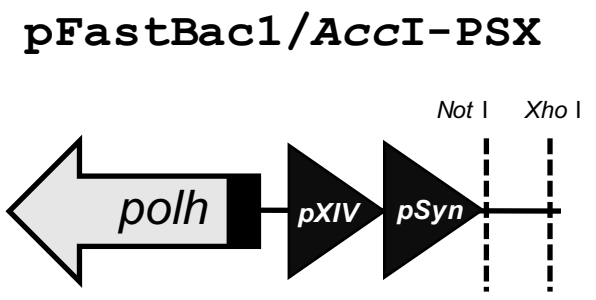

Figura 6. Esquema das duas regiões usadas para fusão da região 'small' do antígeno HBsAg à poliedrina. (a) Região de interesse do plasmídeo de fusão pFastAcPH3, mostrando o sítio de Nco I para clonagem do antígeno e a cauda de hexa-histidina. (b) Região de interesse do plasmídeo de fusão pFastBac1/Accl-PSX, mostrando o gene extra da poliedrina, os promotores híbridos pSyn/pXIV e o sítio de Not I e Xho I para clonagem do antígeno sHBsAg.

\section{Obtenção de baculovírus recombinantes para expressão da região sHBsAg fusionada à poliedrina}

Os plasmídeos de fusão gerados contendo os genes quiméricos (genes de interesse fusionado a polh na região 3' ou plasmídeo com gene extra da poliedrina selvagem) foram utilizados para construção de baculovírus recombinante via sistema Bac-to-bac (Invitrogen), conforme instruções do fabricante. 


\section{Produção in vitro da proteína quimera sHBsAg}

Um micrograma $(\mu \mathrm{g})$ do DNA plasmidial dos bacmídeos recombinantes gerados, foram utilizados para transfectar $10^{6}$ células de inseto (Tn5B). Foi adicionado um volume de 10 microlitros $(\mu \mathrm{L})$ de DNA plasmidial dos bacmídeos $(1 \mu \mathrm{g})$ em $90 \mu \mathrm{L}$ de meio de cultura TC-100 sem soro (Gibco-BRL) em placas de $35 \mathrm{~mm}$ e misturado. Posteriormente, foram adicionados $6 \mu \mathrm{L}$ de lipossomos catiônico da marca FuGENE® HD Transfection Reagent (Promega). A mistura contendo os lipossomos/DNA de cada bacmídeo foram misturados e incubados por 15 min à temperatura ambiente.

Placas com $10^{6}$ células em dois $\mathrm{mL}$ foram incubadas com a mistura lipossomos/DNA de cada bacmídeo por 4 horas a $28^{\circ} \mathrm{C}$. Após 4 horas, a placa foi recomposta com mais dois mililitro $(\mathrm{mL})$ de meio de cultura TC-100 contendo $10 \%$ de soro fetal bovino e incubada a $28^{\circ} \mathrm{C}$ por sete dias. As células de inseto que foram transfectadas com o DNA do baculovírus recombinante foram capazes de produzir vírus, pois como é sabido que o DNA nu do baculovírus é infectivo (Burand et al, 1980). Em uma nova placa de $75 \mathrm{~cm}^{2}$, contendo $5 \times 10^{6}$ células de inseto Tn5B foram adicionados $500 \mu \mathrm{L}$ do sobrenadante da transfecção para amplificação dos vírus recombinantes. O DNA viral foi purificado pelo método de mini preparação como descrito por (O'Reilly et al, 1992). O DNA extraído foi utilizado para confirmação por meio de uma reação de PCR para os genes heterólogos.

\section{Analises microscópicas}

Monocamadas de células Tn5B (aproximadamente $10^{5}$ células) foram incubadas com meio contendo multiplicidade de infecção (termo geralmente abreviado por m. o. i., do inglês, multiplicity of infection que representa o número de partículas virais maduras e infectivas [vírions] para cada célula) de 10 vírus/célula com os vírus recombinantes. As células infectadas foram observadas e fotografadas a $72 \mathrm{~h}$ p.i. em um microscópio de luz invertida Axiovert 100 (Zeiss). Para microscopia eletrônica de varredura (MEV), os possíveis cristais purificados de cadáveres de inseto foram lavados com PBS 
1X. Posteriormente, as amostras foram desidratadas com uma série ascendente de acetona para serem secas ao ponto crítico (Balzer CPD30) e cobertas com ouro no aparelho "sputter coater" (Balzer SCD 050). As amostras foram, então, analisadas no microscópio de varredura JEOL JSM 840 a10 kV.

\section{Análise da expressão e purificação das proteínas recombinantes em larvas de Spodoptera frugiperda e em cultura de células de insetos}

Aproximadamente $10 \mu \mathrm{L}$ do sobrenadante de células Tn5B (96 h p.i.) infectadas com o vírus recombinantes ( $10^{6}$ virus em forma de fenótipo $B V$ ) foram injetados em larvas de Spodoptera frugiperda quarto instar, no segundo par de falsas patas por meio de uma agulha e seringa de $1 \mathrm{~mL}$. As larvas foram separadas individualmente para que não houvesse canibalismo e alimentadas com dieta artificial preparada segundo (Hoffmann-Campo et al, 2003). Após 5 dias, as larvas já apresentavam estágio avançado de infecção, tais como perda do apetite, clareamento da epiderme devido ao acúmulo de vírus nos núcleos das células epidermais e adiposas, parada no desenvolvimento larval e letargia (Federici, 1997). No sexto dia pós-infecção, as larvas estavam mortas ou em processo de morte. Após a morte, os cadáveres foram homogeneizados com o mesmo volume de PBS (p/v), filtrado com gaze e centrifugado a $7.000 \times g$ por 10 min. O sobrenadante foi descartado e o sedimento ("pellet") ressuspendido em um volume de $5 \%$ Triton X-100 e centrifugado a 7,000 x g por 10 min (duas vezes). O último "pellet" foi ressuspendido em $0,5 \mathrm{M} \mathrm{NaCl}$, centrifugado como descrito acima, e ressuspendido com PBS. Todas as soluções continham inibidor de protease que inibe serina, cisteína e metaloproteases (Protease Inhibitor Cocktail -Sigma). As soluções ressuspendidas foram colocadas em um gradiente descontinuo de sacarose $(40-80 \%$ de sacarose em Phosphate Buffered Saline [PBS], 137,0 mM NaCl, 2,7 mM KCl, 10,0 mM Na2HPO4, 2,0 mM KH2PO4, pH $7,4)$ e centrifugada a $130.000 \times \mathrm{g}$ por $75 \mathrm{~min}$. As bandas que continham os possíveis cristais foram removidas do gradiente, diluídas em $d_{d H_{2}} \mathrm{O}$, e centrifugadas a $7.000 \times \mathrm{g}$ por $10 \mathrm{~min}$, o "pellet" foi ressuspendido em um $\mathrm{mL}$ de PBS e estocados a $-20^{\circ} \mathrm{C}$. 
Uma alíquota de $10 \mu \mathrm{L}$ desses possíveis cristais purificados de larvas foram analisados por eletroforese em dois géis desnaturantes de poliacrilamida (SDS-PAGE) a 12\% (Green \& Sambrook, 2012). Um dos géis foi corado e fixado em solução de $40 \%$ de metanol e $10 \%$ de ácido acético e azul de Coomassie $0,1 \%$, por cerca de $16 \mathrm{~h}$ e descorado em solução de $40 \%$ de metanol e $10 \%$ de ácido acético por $4 \mathrm{~h}$, sob leve agitação. $\mathrm{O}$ outro gel foi utilizado para transferência das proteínas para uma membrana de Nitrocelulose (GE Healthcare), para o experimento de imuno-detecção de proteínas ("Westernblot") abaixo descrito. As proteínas foram transferidas para membrana de Nitrocelulose, usando-se o aparato de transferência da Bio-Rad (Trans-Blot $®$ SD - Semi Dry Transfer Cell, para transferência semi-seca), de acordo com o protocolo do fabricante e com tampão de transferência Bjerrum and SchaferNielsen (48 mM de Tris; 39 mM de glicina; $20 \%$ metanol, pH 9,2). Após a transferência, a membrana foi bloqueada com solução de PBS 1X e $3 \%$ de leite em pó desnatado por $16 \mathrm{~h}$ a $4^{\circ} \mathrm{C}$, sendo em seguida processada para a imunomarcação. O primeiro passo foi lavar a membrana por 3 vezes com PBS Tween $(0,05 \%)$ para retirar toda a solução de bloqueio e em seguida colocar a membrana em uma solução de PBS/albumina bovina (BSA) 0,5 \% adicionada do anticorpo primário anti-6xHIS (GE Healthcare) de coelho por $1 \mathrm{~h}$. Essa solução foi então descartada e a membrana foi lavada novamente por 3 vezes em PBS Tween $(0,05 \%)$ sob agitação suave. A seguir, a membrana foi colocada em uma solução de PBS/BSA 0,5\% contendo o anti-lgG de coelho conjugado à enzima fosfatase alcalina (Sigma) por mais uma $1 \mathrm{~h}$ sob agitação suave. Esta solução foi então, retirada e a membrana é lavada novamente com PBS Tween $(0,05 \%)$ por 3 vezes e com o tampão da enzima fosfatase alcalina por 5 min com agitação suave. $O$ revelador foi adicionado logo a seguir, trata-se de uma solução de NBT/BCIP (Promega). A combinação de NBT (cloreto de tetrazólio nitro-azul) e BCIP (sal de 5-bromo-4-cloro-3'-p-toluidina indolil fosfato) produz um insolúvel precipitado negro-púrpura intensa quando reage com fosfatase alcalina, que é uma popular enzima conjugada para sondas de anticorpo. A reação precisa ser interrompida com sucessivas lavagens com água destilada para que não ocorra marcação inespecífica ou dano à qualidade do resultado obtido. 


\section{Imunização e produção de antissoro}

Os cristais de Polh de AcMNPV e os possíveis cristais fusionados com HBsAg na amino-terminal (6xhis-HBsAg-Polh) purificados de células de insetos/larva por gradiente de sacarose foram dissolvidos por uma hora a $37{ }^{\circ} \mathrm{C}$ em $0.1 \mathrm{M}$ de $\mathrm{Na}_{2} \mathrm{CO}_{3}$ ou até a dissolução de todos os cristais, neutralizados com $0.1 \mathrm{M}$ de Tris- $\mathrm{HCl}$ ( $\mathrm{pH}$ 7.6), e submetidos a quantificação de proteina total utilizando Quant-iTTM assay kit (Thermo Scientific) seguindo as instruções do fabricante. Os cristais de POLH e os cristais recombinantes previamente quantificados por sua totalidade proteica e utilizados para imunização em Camundongos Balb/c de 6-8 semanas por via subcutânea, foram utilizados a concentração de $100 \mu \mathrm{g}$ de proteína total em um volume final de $200 \mu \mathrm{L}$ em intervalos de 15 dias entre cada imunização. A primeira inoculação foi ministrada com adjuvante incompleto de Freund (Sigma Aldrich) na proprção de 1:1, a segunda e a terceira imunização foi ministrada somente com os cristais. Após 15 dias da última imunização, os camundongos foram sacrificados e o sangue periférico obtido por retrorbital para obtenção do soro.

\section{Imunoensaio}

Os possíveis cristais fusionados com sHBsAg purificados de larva por gradiente de sacarose foram quantificados utilizando Quant-iTTM assay kit (Thermo Scientific) seguindo as instruções do fabricante. Foram realizados testes sorológicos imunoenzimáticos, ELISA (Enzyme-linked Immunosorbent Assay) direto do tipo sanduíche, método que se baseia na interação anticorpoantígeno. As cavidades da placa de ELISA foram cobertas com $50 \mu \mathrm{L}(0,5 \mathrm{ng} / \mathrm{mL})$ antígeno sHBsAg fusionada a poliedrina (proteína recombinante). Pós incubação de uma hora por $37^{\circ} \mathrm{C}$, utilizamos como controle positivo, soro/plasma contendo anticorpos anti-HBsAg comercial e controle negativo, soro/plasma sem anticorpos anti-HBsAg comercial (Wama Diagnóstica) que foram adicionadas $50 \mu \mathrm{L}$ às cavidades juntamente com um conjugado HBsAg marcado com peroxidase, porém o "branco" continha soro/plasma sem anticorpos anti-HBsAg e conjugado. Após a incubação de uma hora por $37^{\circ} \mathrm{C}$, ocorre a formação de um complexo antígeno-anticorpo-antígeno representado pelo conjugado HBsAg 
marcado com peroxidase, pelo anticorpo anti-HBsAg da amostra e pelo antígeno HBsAg ligado à cavidade da microplaca. O material não ligado é removido por

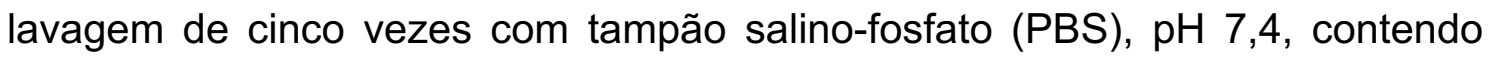
Tween 20 como detergente. Um substrato (Tetrametilbenzidina [TMB] + peróxido de hidrogênio) foi adicionado, o qual desenvolve cor azul nas cavidades onde a enzima peroxidase estiver presente, indicando a presença do anticorpo antiHBsAg. A adição de uma solução de parada da reação enzimática (ácido sulfúrico $\mathrm{H}_{2} \mathrm{SO}_{4} 1,0 \mathrm{M}$ ), produz uma mudança de cor da solução para amarela. A absorbância foi então medida a $450 \mathrm{~nm}$ em leitor de placa de ELISA. A concentração do anticorpo anti-HBsAg é diretamente proporcional a intensidade da cor da reação. Os resultados foram calculados em relação aos soros controles e densidade óptica (D.O.), cujo valor final é obtido subtraindo da leitura da D.O. do "branco". O resultado deve ser interpretado de acordo os controles negativos, onde divide se o valor da D.O. da amostra pelo valor do cut-off. O teste é considerado reagente se o valor for duas vezes o valor do controle negativo.

\section{Resultados}

\section{Obtenção e clonagem antígeno sHBsAg}

O fragmento contendo a região codificadora da proteína sHBsAg (Figura 8-A) foi amplificada por PCR a partir do DNA viral de células de inseto transfectado com o vírus recombinante vAc-6xHis-sHBsAg-AcPH (Araujo, 2011), utilizando os pares de iniciadores pFast-AminoR e pFast-AminoF (Tabela 2), gerando um fragmento de 1.452 pares de base (Figura 8-B). Esse fragmento foi purificado do gel e ligado no vetor de clonagem $p G e m \circledast-T$ easy gerando o $p G E M-$ sHBsAg-AcPH com 4.482pb (Figura 8-C). O plasmídeo recombinante foi obtido e sua sequência confirmada por digestão e sequenciamento. 
A

\section{6xHis-sHBsAg}

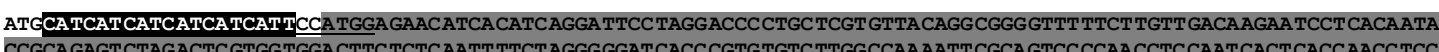
CCGCAGAGT CTAGACTC GTGGTGGACTTC TCTCAATT TTCTAGGGGAT CACC CGTGTGTC TTGGCCAAAATT CGCA GTCCCCAACCTC CAAT CACT CACCAACC TCC TGTCC TCCAATTT GTCCTGGT TATCGCTG GATGTGTC TGCGGCGT TTTA TCATATTCCTCT TCATCCTGCTGC TATGCCTCATCT TCTT ATTGGTTC TTCT GGAT TAT CAAGG TATG TTGCCCGT TTGTCCTC TAAT TCCAGGAT CAACAACAACCAGTACGGGACCAT GCAAAACC TGCACGAC TCCTGCTCAAGGCAAC TCTAAGTT TCCC TCA TGTTGCTGT ACAAAACC TACG GATG GAAA TTGCACCT GTAT TCCCATCCCATC GTCC TGGGCTTT CGCAAAAT ACCT ATGGGAGT GGGCCTCA GTCC GTTT CTCT TGG CTCAGTTTACTAGTGCCATTTGTTCAGTG GTTCGTAGGGCT TTCCCCCACTGT TTGGCTTT CAGCTATA TGGA TGAT GTGGTATT GGGGGCCAAGTCTGTACAGCATC CTCAGTTTACTAGTGCCATTTGTTCAGTG GTTCGTAGGGCT TTCCCCCACTGT TTGGCTTTC

B

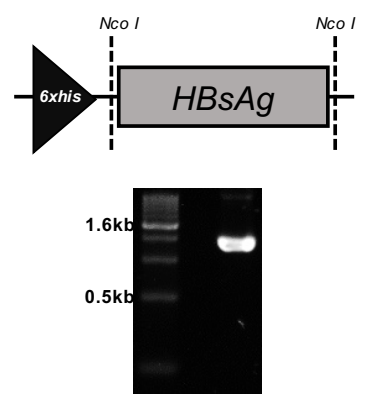

C

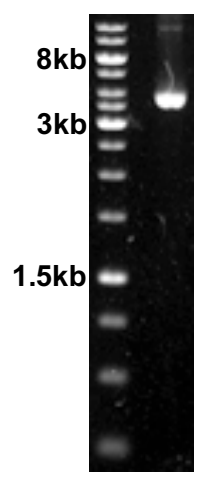

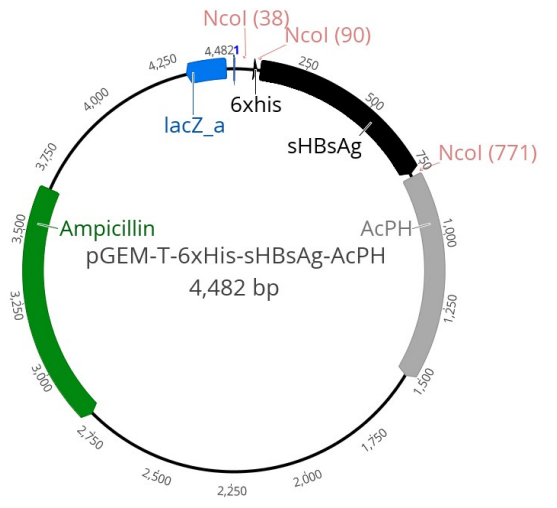

Figura 7. Esquema mostrando a sequência de construção do vetor pGem-HBsAg. (A) Sequência nucleotídica do gene $6 \mathrm{xHis-sHBsAg.} \mathrm{(B)} \mathrm{esquema} \mathrm{do} \mathrm{fragmento} \mathrm{do} \mathrm{gene} \mathrm{HBsAg}$ e gel de agarose $0,8 \%$ com o fragmento de PCR apresentando $1.452 \mathrm{pb}$, resultado da reação de PCR com os iniciadores pFast-AminoR e pFast-AminoR, e (C) gel de agarose 0,8\% mostrando o fragmento de DNA correspondente ao o pGEM-sHBsAg-AcPH com 4.482pb e o mapa do plasmídeo recombinante derivado do vetor $\mathrm{pGem}{ }^{\circledR}-\mathrm{T}$ easy gerado.

\section{Construção do vetor de transferência pFastAcPH3- sHBsAg e pFastBac1/Accl-PSX-6xHis-sHBsAg-AcPH}

Para a construção do pFastAcPH3-sHBsAg e pFastBac1/Accl-PSX6xHis-sHBsAg-AcPH o pGEM-T-6xHisHBsAg foi digerido com a enzima Nco I liberando um fragmento de aproximadamente $700 \mathrm{pb}$ que representa o gene sHBsAg (Figura 9-a e A), para ligação no pFastAcPH3 (Figura 9-b e B), e com Xho I/EcoR I, gerando um fragmento de aproximadamente $1.473 \mathrm{pb}$ da fusão sHBsAg-AcPH (Figura 10-a e A) para ligação no pFastBac1/Accl-PSX (Figura 10-b e B). Após eletroforese em gel de agarose a 0,8\%, as bandas foram eluídas e ligadas aos seus respectivos vetores previamente digeridos com Nco I ou Xho I/EcoR I, dando origem ao plasmídeo pFastAcPH3-sHBsAg (Figura 9-c e C). Esses plasmídeos foram sequenciados e para confirmação da orientação da clonagem, o pFastAcPH3-sHBsAg foi digerido com a enzima Hind III ( 1.297bp) 
(Figura 9-D) e o pFastBac1/Accl-PSX-6xHis-sHBsAg-AcPH foi digerido com Hind III (Figura 10-C).

a

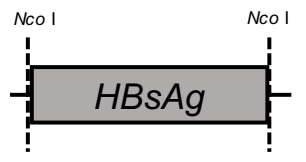

A

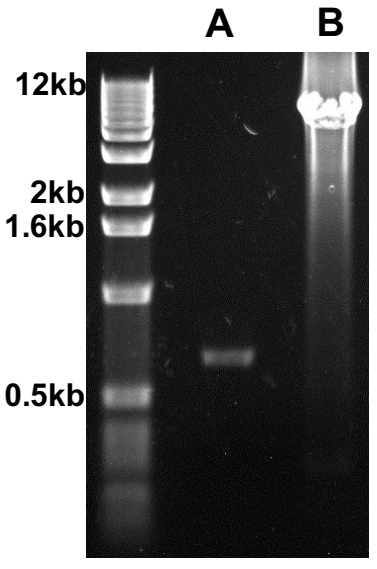

b

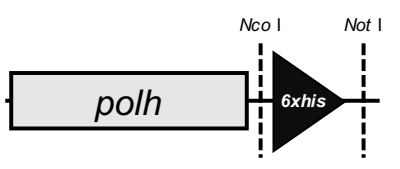

C

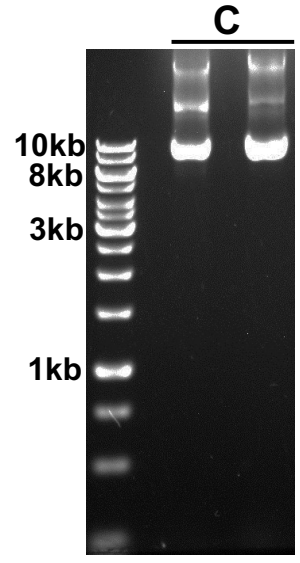

C

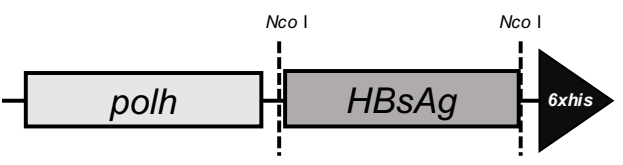

D

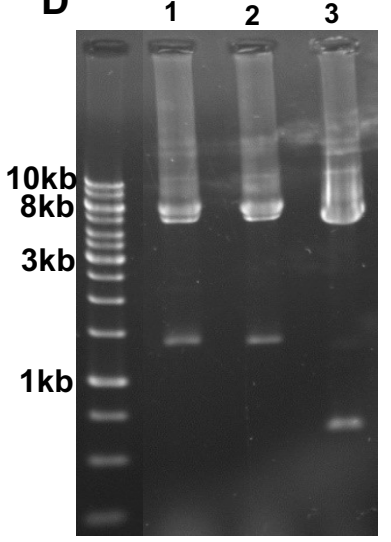

Figura 8. Construção do vetor de transferência pFastAcPH3sSHBsAg. a, b e c mostram os esquemas dos genes HBSAg, polh e fusão polh-HBSAg, respectivamente, com a posição dos sítios para as enzimas de restrição Nco I e Not I. (A) Gel de agarose 0,8\% mostrando framento de 700 pb que foi purificado a partir da digestão do DNA do plamídeo pGEM-T-6xHisHBsAg com a enzima Nco I. (B) Fragmento de DNA do plasmídeo pFastAcPH3 digerido com a enzima Nco I e desfosforilado. (C) DNA do plasmídeo de transferência pFastAcPH3sHBsAg e (D) o mesmo vetor digerido com a enzima Hind III, (1 e 2) orientação correta liberando um fragmento de aproximadamente 1.297bp e (3) orientação errada. Em b e c, 6xhis representa seis histidinas.

a

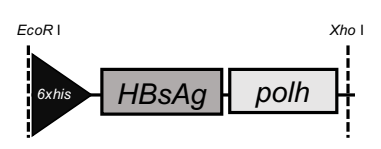

b

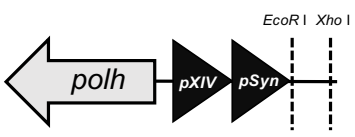

B

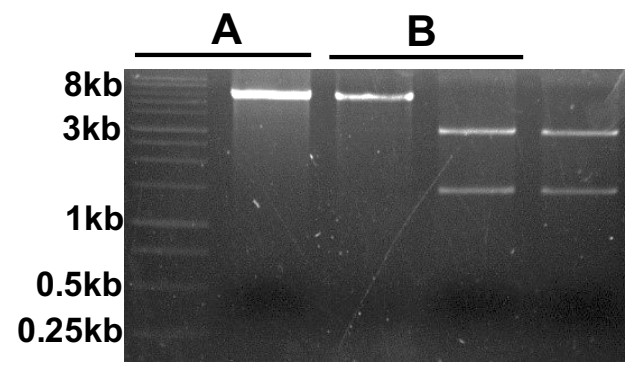

C
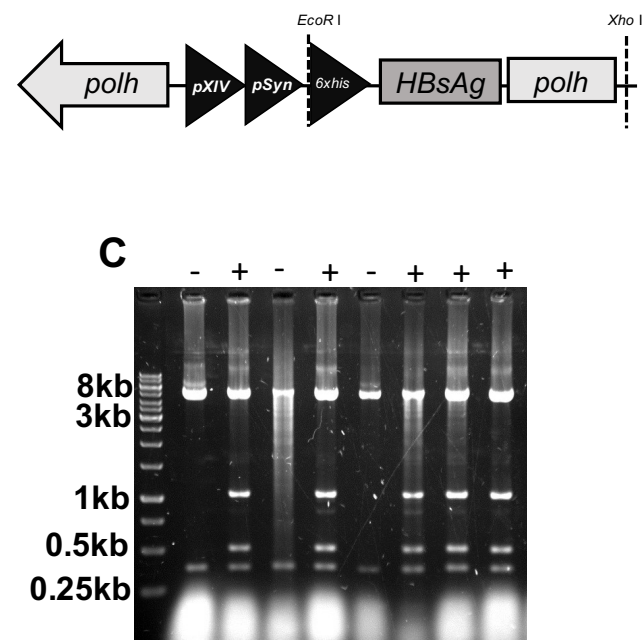

Figura 9. (a, b e c) Esquema da construção do vetor de transferência pFastBac1/Accl-PSX6xHis-sHBsAg-AcPH (com o gene extra da poliedrina do AcMNPV). (A) Vetor pGEM-T6xHisHBsAg foi digerido com a enzima Xho I/EcoR I liberando um fragmento de aproximadamente 1.473pb do sHBsAg-AcPH. (B) pFastBac1/Accl-PSX digerido com a enzima Xho I/EcoR I. (C) o mesmo vetor agora nomeado pFastBac1/ Accl-PSX-6xHis-sHBsAg-AcPH 
digerido com a enzima Hind III, sendo a orientação correta liberando quatro fragmentos de $5.100,1.284,440$ e 356 pb e a orientação errada somente dois fragmentos de 5.100 e 356 pb referente ao vetor vazio. (+) orientação correta e (-) orientação errada.

\section{Construção do vírus contendo as fusões PH3sHBsAg e Accl-PSX-6xHis-sHBsAg-AcPH}

Os vírus contendo as fusões gênicas PH3sHBsAg e Accl-PSX-6xHissHBsAg-AcPH foram gerados utilizando o sistema Bac-to-bac (Invitrogen), conforme instruções do fabricante, sendo denominados vAcPHHB1 e vAcHBsPH2. O DNA do possível vAcPHHBs foi confirmado por PCR utilizando os iniciadores M13F e R, gerando uma banda de aproximadamente $3.500 \mathrm{pb}$ (Figura $11 \mathrm{~A}$, poço 4) e o vAcHBsPH2 foi confirmado utilizando os iniciadores HBSAgRNco ICOMHIS e M13F (Tabela 2), gerando uma banda de 3.298pb (Figura 12-A, poços 3, 4 e 6).

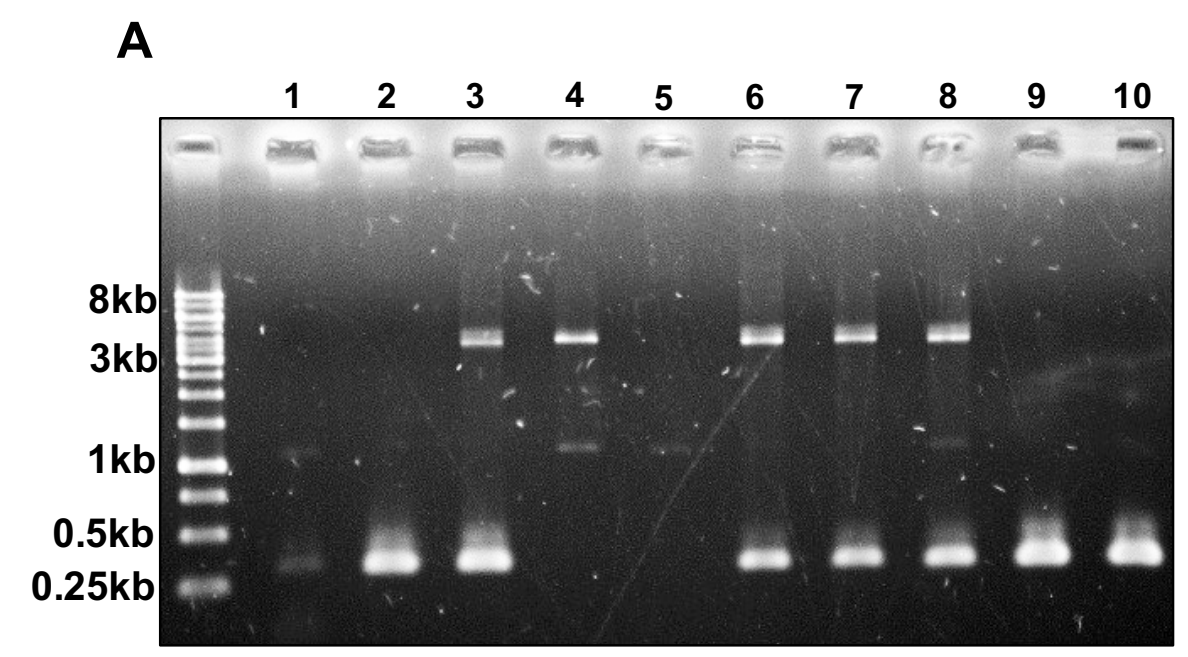

Figura 10. Confirmação da construção do bacmídeo vAcPHHBs. (A) gel de agarose a $0,8 \%$ mostrando resultado da PCR de possíveis clones contendo o bacmídeo recombinante. $O$ plasmídeo pFastAcPH3sHBsAg contendo o gene HBsAg foi transformado em células DH10-Bac. Além do gene sHBSAg, o cassete contém um gene de resistência a gentamicina, o promotor da poliedrina, o gene da poliedrina em fusão com o gene sHBsAg e uma cauda de 6 histidinas. $O$ cassete foi transposto para o bacmídeo interrompendo o peptídeo lacZ- $\alpha$ e evitando a $\alpha$ complementação da enzima $\beta$-galactosidase e denominado vAcPHHB1. Após coleta das colônias recombinantes, a presença do gene sHBsAg foi confirmada por PCR utilizando os iniciadores M13F e M13R gerando um fragmento de tamanho de $3.500 \mathrm{pb}$. A amostra de número quatro foi selecionada para continuar com os experimentos. 


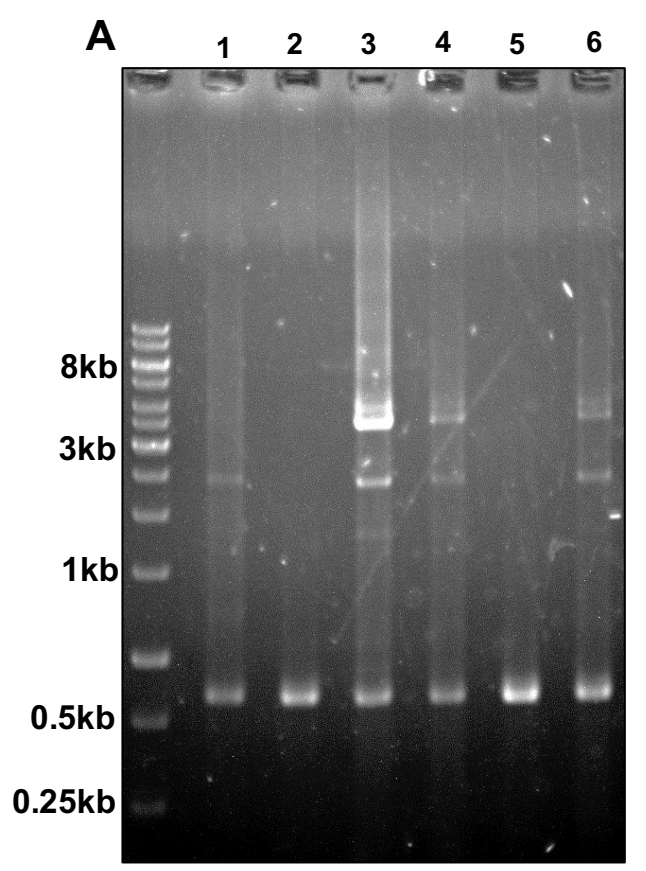

Figura 11. Confirmação da construção do bacmideo bacvAcHBsPH2. (A) O plasmídeo AcclPSX-6xHis-sHBsAg-AcPH contendo o gene sHBsAg-AcPH foi transformado em células DH10Bac. O cassete contém o gene sHBsAg fusionado na região 5' do $\mathrm{AcPH}$ (sHBsAg-AcPH), mais um gene extra da poliedrina do AcMNPV, um gene de resistência a gentamicina e uma cauda de 6 histidinas. O cassete foi transposto para o bacmídeo interrompendo o peptídeo lacZ-a evitando a $\alpha$-complementação da enzima $\beta$-galactosidase e denominado bacvAcHBsPH2. Após coleta das colônias recombinantes, a presença do gene sHBsAg-AcPH foi confirmada por PCR utilizando os iniciadores HBSAgRNco ICOMHIS e M13R gerando um fragmento de tamanho de $3.298 \mathrm{pb}$.

Tabela 1. Iniciadores utilizados no trabalho

\begin{tabular}{|l|l|}
\hline Iniciadores & Sequência de nucleotídeos $\left(\mathbf{5}^{\prime} \boldsymbol{\rightarrow} \mathbf{3} \mathbf{3}^{\mathbf{}} \mathbf{)}\right.$ \\
\hline pFast-AminoF & GGATCCCATATGCATCATCATCATCATCATTCCATGG \\
\hline pFast-AminoR & GGATCCCTCGAGTTAATACGCCGGACCAGTGAACAGA \\
\hline M13-F & GCCAGGGTTTTCCCAGTCACGAC \\
\hline M13-R & CACAGGAAACAGCTATGACCATGATT \\
\hline HBSAgRNco ICOMHIS & CCATGGAAATGTATACCCAGAGACAA \\
\hline
\end{tabular}

\section{Análise da expressão da proteína recombinante e estrutural de possíveis cristais da proteína quimera sHBsAg em insetos}

Monocamadas de células Tn5B (aproximadamente $10^{5}$ células) foram incubadas em meio de cultura contendo 10 vírus/célula com vAc-6xHis-sHBsAgAcPH (Araújo, 2011) denominado vAcHBsPHs e os dois vírus construídos nesse 
trabalho. Após um período de 72 h.p.i, as células apresentaram o núcleo hipertrofiado, rugoso, com presença de possíveis poliedros (Figura 13). Extratos dessas células (Tn5B) infectadas com os vírus recombinantes 72 h.p.i foram analisados por eletroforese em dois géis desnaturantes de poliacrilamida (SDSPAGE) a $12 \%$ (Green \& Sambrook, 2012) (Figura 14-A) e as proteínas transferidas para uma membrana de nitrocelulose (GE Healthcare), para o experimento de imuno-deteç̧ão de proteínas ("Western-blot"). As proteínas foram detectadas usando anticorpo anti-hexa-histidina (anti-6xHis) (Figura 14-B) e anticorpos produzindos em camundongos contra a Polh-AcMNPV (Figura 14C) e anti-6xHis-sHBsAg-AcPH (Figura 14-D). Uma banda imunorreativa de 53,7 $\mathrm{kDa}$ foi detectada, referente a fusão do sHBsAg com a POLH, os anticorpos produzidos em camundongos (Polh-AcMNPV e anti-6xHis-sHBsAg-AcPH) também reagiram contra a POLH sendo observada uma banda imunoreativa de aproximadamente $30 \mathrm{kDa}$, como o esperado, por conta da fusão com a POLH (Figura14 C e D).

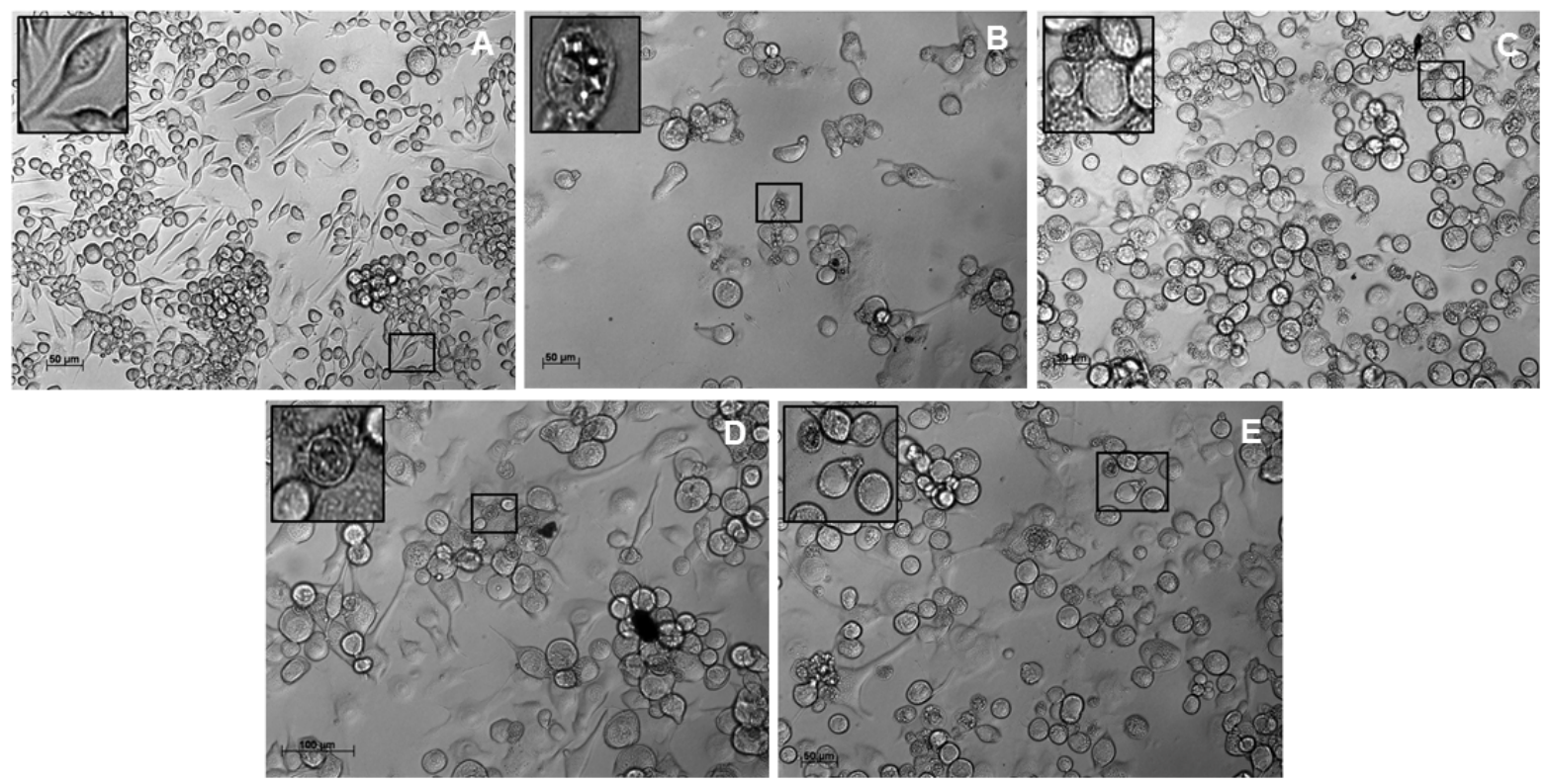

Figura 12. Análise do efeito citopático da infecção de células Tn5B com diferentes baculovírus a 72h.p.i. Células de inseto Tn5B não infectadas (A) ou infectadas (B, C, D e E) com diferentes recombinantes ou vírus selvagem. Células infectadas com o vírus AcMNPV (B); com vAcPH3 (C), vAcPHHB1 (D) e vAcPHHB2 (E). OBs ou poliedros são mostrados no núcleo das células $B$ e corpos de oclusão de morfologia disforme e em agregados C, D e E. 

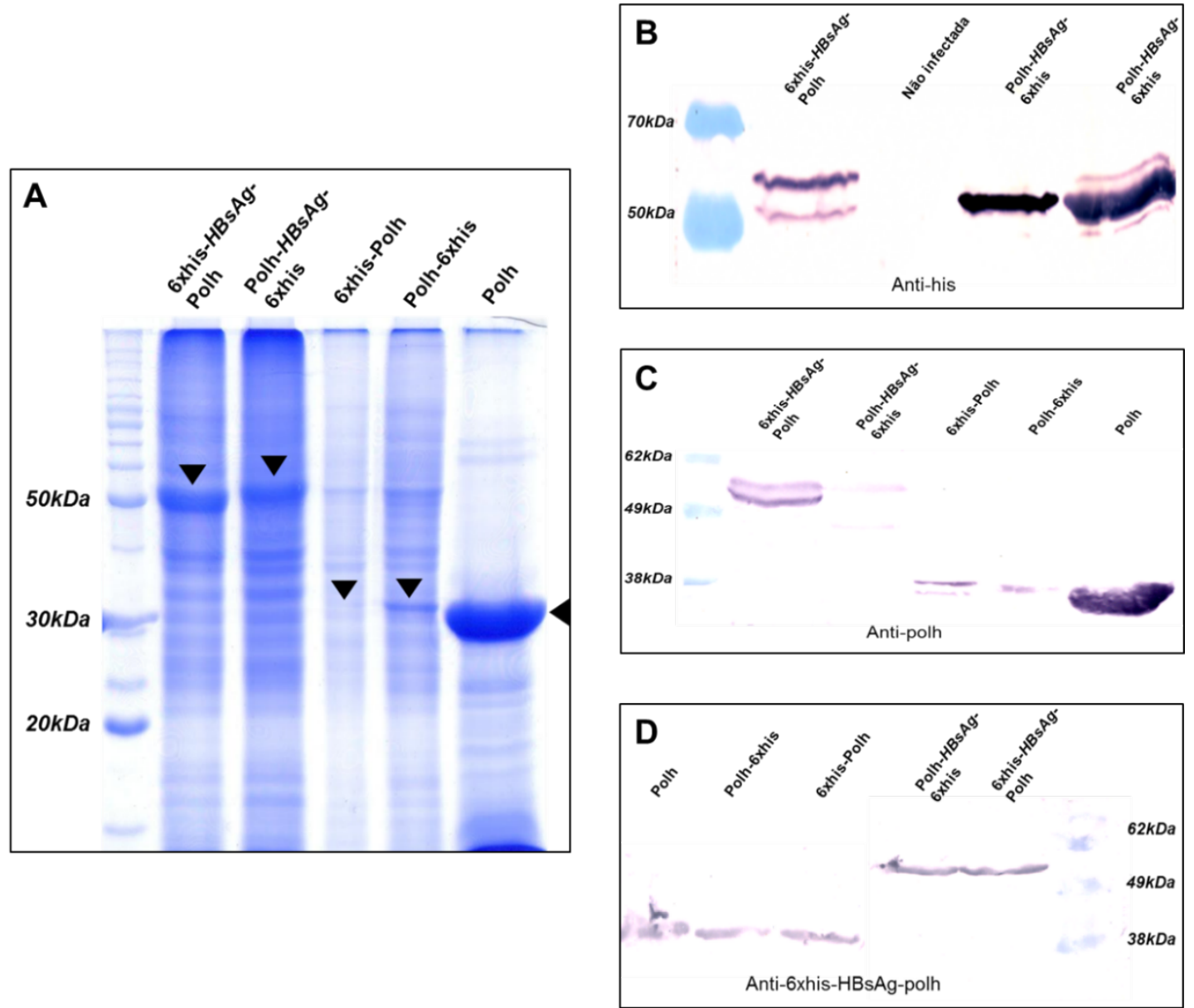

Figura 13. Análise da expressão da proteína recombinante sHBsAg em células de inseto infectadas com o baculovírus recombinante vAcPHHBs e vAcHBsPH2. (A) SDSPAGE $12 \%$ de extratos de células de inseto infectados com diferentes baculovírus recombinants. Análise de Western blot de extratos de células de inseto infectados com diferentes baculovírus recombinants: (B) A membrana foi imunomarcada com anti-6xHIS (Promega), (C) anti-Polh e (D) anti-6xhis-HBsAg-Polh como anticorpo primário, incubadas com anti-lgG de coelho conjugado a enzima fosfatase-alcalina (Invitrogen) e a proteína foi detectada utilizando o substrato NBT / BCIP (Promega). A mesma banda de 53,7 kDa do SDS-PAGE gel é observada na membrana, que foi reconhecida pelos anticorpos.

Lagartas de Spodoptera frugiperda foram infectadas no quinto instar por injeção de sobrenadante das células Tn5B infectadas pelos vírus recombinantes, após 5 dias, as lagartas mortas foram coletadas e os possíveis cristais derivados da fusão da proteína poliedrina com sHBsAg foram purificados em gradiente de sacarose e observados em MEV, podendo ser vistos corpos de oclusão de morfologia disforme e em agregados (Figura15). 
6xhis-HBsAg-Polh

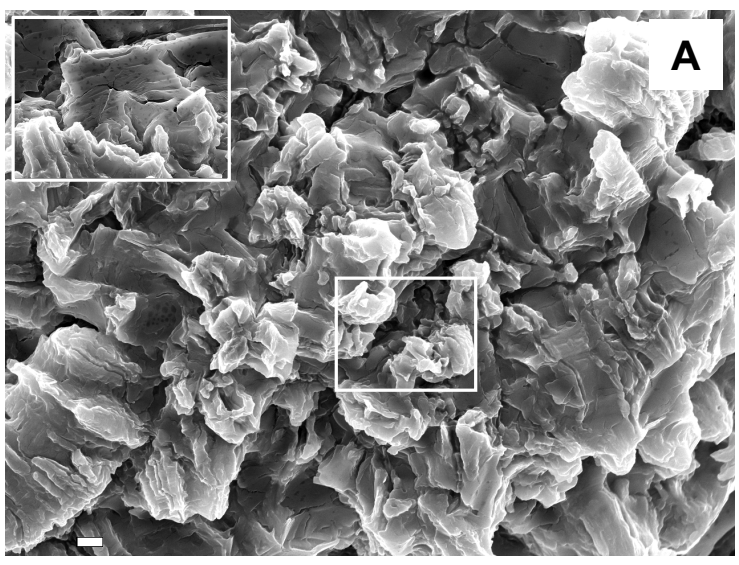

Polh-HBsAg-6xhis

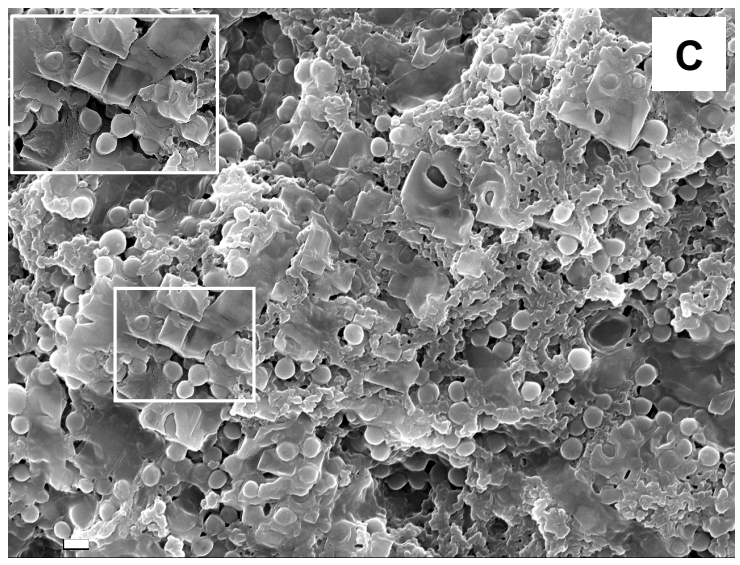

6xhis-Polh

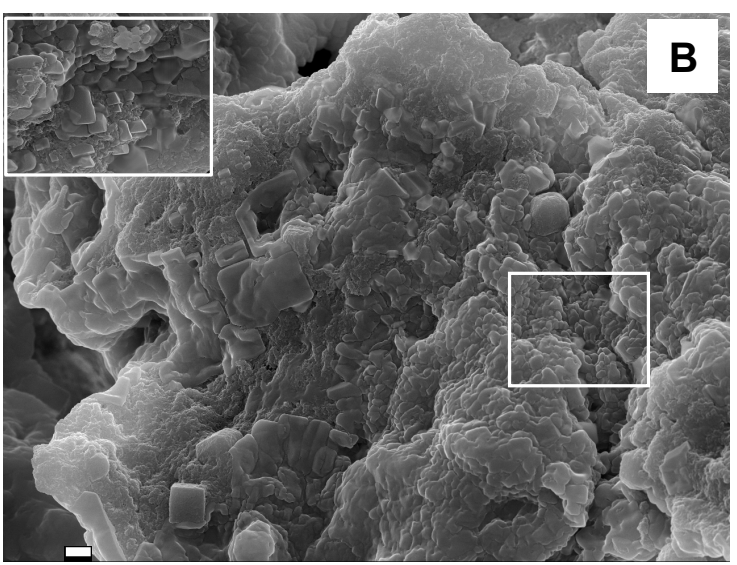

Polh-6xhis

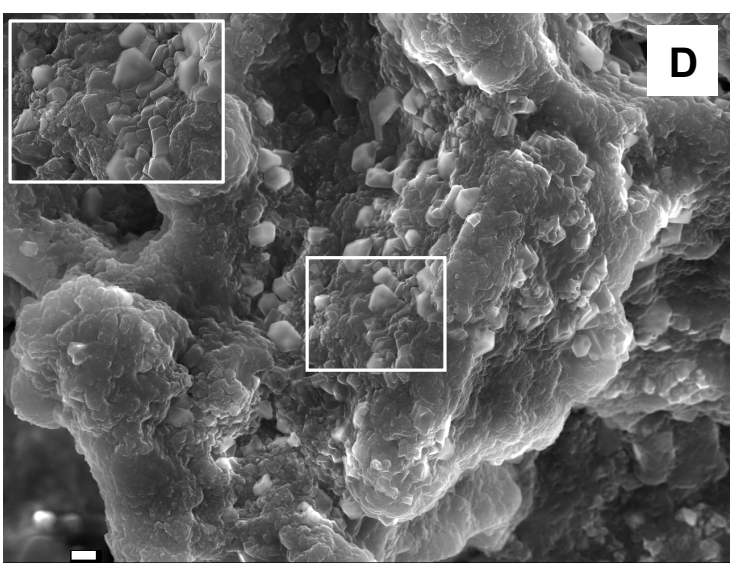

Figura 14. Analise ultraestrutural dos corpos de oclusão derivados de larvas de $S$. frugiperda infectadas pelos vírus recombinantes. Possíveis cristais de 6xhis-HBsAg-Polh (A), 6xhis-Polh (B), Polh-HBsAg-6xhis (C) e Polh-6xhis (D) de cadáveres S. frugiperda foram purificados por gradiente de sacarose. OBs foram coletados do gradiente de sacarose e preparados para MEV. É possível observar um acúmulo de uma estrutura cristalina sem forma definida (barra $=1 \mu \mathrm{m}$ ).

\section{Imunoensaio com Kit comercial Anti HBsAg}

Corpos de oclusão produzidos em lagartas Spodoptera frugiperda infectadas com os vírus recombinantes (Figura 16) foram testadas contra o Kit Laboratorial anti HBsAg qualitativo e quantitativo da empresa Wama Diagnóstica. Para o teste qualitativo foram avaliadas cinco concentrações diferentes das proteínas totais produzidas neste trabalho (100ng, 200ng, 300ng, $400 \mathrm{ng}$ e 500ng), sensibilizadas na cavidade da microplaca de ELISA da marca Costar. Todas as cinco concentrações testadas contra o controle positivo (soro humano positivo para anti-HBsAg) disponível no kit, obtiveram reação positiva. A concentração de $100 \mathrm{ng}$ de proteína total dos OBs recombinantes foi selecionada para determinar o valor mínimo detectátvel em relação a 
concentração de anticorpo anti-HBsAg em soro (10, 20, 40, 80 e $160 \mathrm{mUl} / \mathrm{mL})$, disponíveis no Kit Laboratorial Anti HBsAg Quantitativo. Utilizamos como controle positivo, soro contendo anticorpos anti-HBsAg e controle negativo, soro sem anticorpos anti-HBsAg disponível no Kit. Todas as cinco concentrações de anticorpo anti-HBsAg em soro testadas reagiram com as proteínas sensibilizadas em microplaca (Figura16).

A

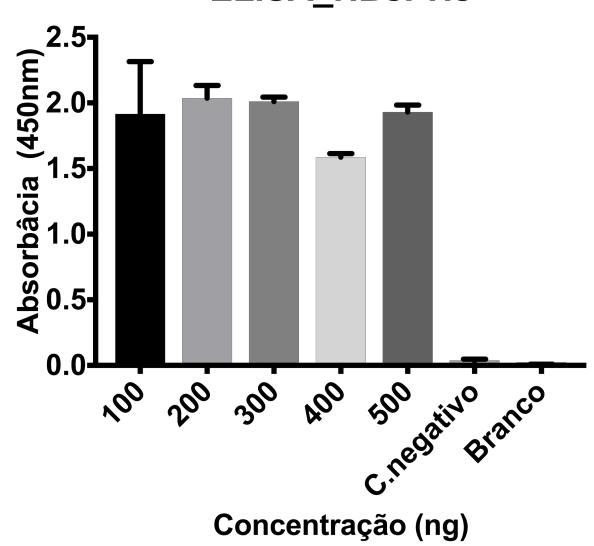

C

ELISA_HBsPHs

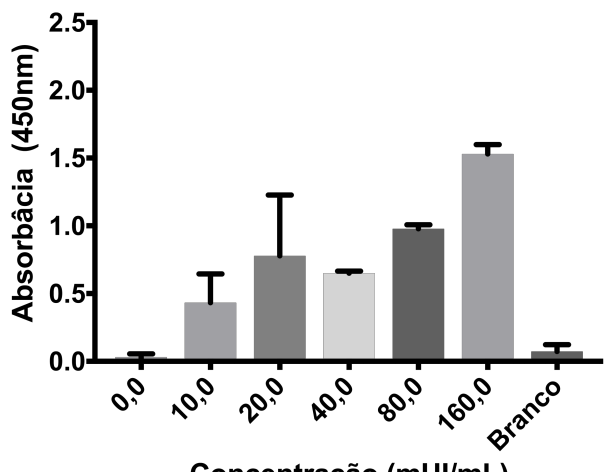

Concentração (mUl/mL)
B

ELISA_HBsPH1

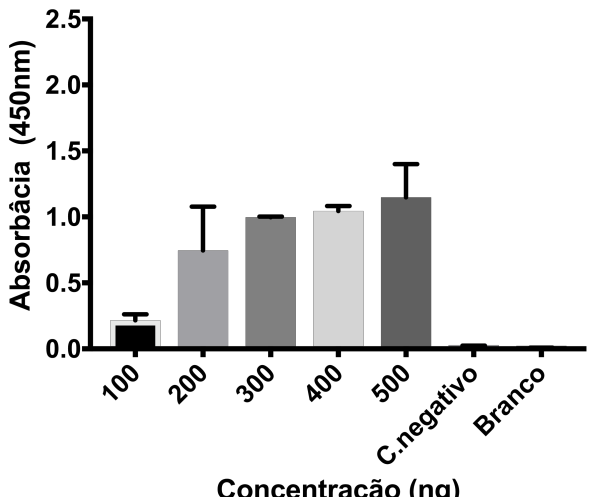

D

ELISA_HBsPH1

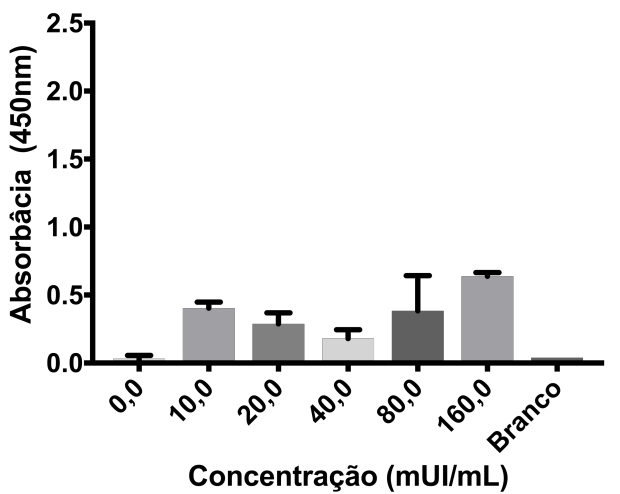

Figura 15. ELISA utilizando Kit Laboratorial Anti HBsAg Qualitativo e Quantitativo da empresa Wama Diagnóstica. Gráfico apresenta o resultado da absorbância $(450 \mathrm{~nm})$ do imunoensaio contendo os OBs recombinantes (HBsPHs e HBsPH1). ELISA qualitativo ( $\mathrm{A}$ e $\mathrm{B}$ ) com diferentes concentrações da proteina recombinante e quantitativo ( $C$ e D) com diferentes concentrações de anti HBsAg em soro comercial. Soro controle negativo (soro humano negativo para anti-HBsAg presente no Kit) e branco (somente substrato cromógeno) Absorbância lida em leitor óptico (spectramax) a $450 \mathrm{~nm}$. 


\section{Discussão e Conclusão}

Foram construídos neste trabalho dois baculovírus recombinantes: o vAcPHHBs, que apresenta o gene sHBsAg fusionado na região 3' do gene polh do AcMNPV e o vAcHBsPH2, que apresenta o gene $s H B s A g$ fusionado na região 5' do polh e uma cópia do gene polh do AcMNPV.

Ji e colaboradores em 2010, mostraram que a região 3' da poliedrina é essencial para a formação dos corpos de oclusão e que a fusão de genes heterólogos na região 3' prejudicaria a montagem da poliedrina. No presente trabalho com a na construção do baculovírus recombinante foi demonstrado que a fusão do sHBsAg na região 3' da polh não resultou na produção de corpos de oclusão semelhantes aos produzidos pelo vírus selvagem. Corroborando com o trabalho anterior citado, foi possível observar a produção de uma massa proteica sem forma definida no núcleo e citoplasma das células infectadas. A formação de uma massa proteica sem forma definida quando ocorre a fusão da proteína HbsAg e outras proteínas com a polh já havia sido demostrado em trabalhos anteriores (Araujo, 2011; Ardisson-Araújo et al, 2013b; Barros, 2011). Como uma outra alternativa para melhorar a produção e formação de poliedros semelhante aos selvagens, foi construído um novo vírus recombinante contendo, além da fusão das proteínas HBsAg e POLH, uma cópia extra do gene polh. No entanto, essa estratégia privilegiou a maior produção de $\mathrm{POLH}$ selvagem em relação à proteína de fusão (dados não amostrados).

A glicoproteína de membrana HBsAg presente no envelope do vírus HBV como descrito por Ganem \& Schneider (2001) é codificada pelo gene pré sS/S que contém as regiões pré $\mathrm{S} 1$, pré $\mathrm{S} 2$ e $\mathrm{S}$. A maior subunidade que compõe o HBsAg é a large $S$, com códon de iniciação localizado no início da região pré S1; a subunidade de tamanho intermediário designada de middle $S$ é codificada pelas regiões pré S2 e S; a menor subunidade, small S, é sintetizada a partir do códon de iniciação localizado no início da região s do HBsAg que é altamente imunogênico. Enquanto na maioria dos kits diagnóstico é utilizado a proteína inteira composta pelas 3 subunidades. Neste trabalho somente a subunidade small $S$ foi utilizada. A subunidade small $S$ foi reconhecida pelos anticorpos antiHBsAg comerciais nos testes de imunoensaio. Lanford et al. (1998), construiu baculovírus (AcMNPV) recombinantes para expressão de proteínas antigênicas 
de superfície do vírus da hepatite $B$, com e sem a região pré-S, fusionado e não fusionado. Para fusão foi utilizado um vetor que contem o polh flanqueada por genes up stream e down stream para facilitar a recombinação homóloga e permitindo a fusão na região $5^{\prime}$ da polh. A proteina fusionada foi purificada por gradiente de Cloreto de césio ( $\mathrm{CsCl}$ ), a não fusionada e não secretada foi purificada de membrana por cromatografia de imunoafinidade com coluna antiHBsAg IgG. As proteínas foram testadas quanto a modificações pós-traducional, antigenicidade e imunogenicidade. Não foi observado diferença dos polipeptídeos fusionados e não fusionados, no que diz respeito a antigenicidade e imunogenicidade quando comparadas com HBsAg derivado de plasma comercial do kit ELISA (Organon Teknika Corporation; Nuclear Medical Laboratories).

A utilização de proteínas recombinantes para a produção de teste de detecção antígeno-específica e produção de vacinas vêm sendo ampliada devido a sua segurança e facilidade. Price et al. (1989), utilizou o sistema de expressão baseado em baculovírus AcMNPV e células de inseto para expressar o antígeno de superfície do HBV, HBsAg, e uma glicoproteína do envelope do vírus Influenza A, neuraminidase (NA). As proteínas recombinantes produzidas por recombinação homóloga sob o comando do promotor polh, foram testadas em imunoensaios e sua antigenicidade foi comprovada com sucesso.

O diagnóstico laboratorial específico confirmatório utilizado hoje para detecção de infecção pelo HBV é realizado por meio de testes sorológicos como o ensaio imunoenzimático (EIA) e Radioimunoensaio (RIA) que buscam identificar no soro humano, os antígenos HBsAg e HBeAg e os anticorpos anti$\mathrm{HBcAg}$, anti-HBeAg e anti-HBsAg. Os laboratórios clínicos, devido à alta demanda de diagnóstico para HBV, têm procurado utilizar kits prontos para realizar os testes diagnósticos poupando tempo e diminuindo os custos. Os laboratórios de referência como os Laboratórios Centrais chegam a realizar mais de mil exames dia para HBV, e isso faz com que a necessidade de utilização de kit de fácil execução, baixo risco de manipulação e menor custo aumente significativamente, incentivando as empresas a buscarem novas técnicas (Roberto, 2007). O teste para detecção de HBsAg é estendido para além de casos de pacientes com suspeita de HBV, mas também para acompanhamento da progressão da doença e para segurança de todo sangue doado nos 
Hemocentros e Bancos de sangue. A produção de HBsAg utilizando o sistema de expressão em baculovírus é uma ferramenta com potencial para ser utilizada na criação de kits diagnóstico para detecção de HBsAg e Anti-HBs, pois, sua produção é simples e não oferece risco de contaminação viral, como demonstrado nesse trabalho.

A imunodetecção realizada neste trabalho foi testada com sucesso utilizando padrões tais como conjugado HBsAg marcado com peroxidase, substrato cromógeno, solução de parada (stop) e soro/plasma como controle negativo e positivo do kit anti HBsAg da empresa Wama Diagnóstica. Além disso, não foi usada do kit somente a placa com 96 poços de poliestireno para ELISA, que foi sensibilizada com a massa proteica fusionada com sHBsAg. Esse resultado demonstra que o sHBsAg produzido em inseto e culturas de células é capaz de ser reconhecido por soro contendo anticorpos anti-HBsAg comercial, por enzimaimunoensaio (ELISA), revelando uma alternativa promissora para produção de kits diagnóstico anti- HBsAg. Isso possibilitaria a produção desses Kits pela indústria nacional, por um menor custo, para utilização em larga escala nos laboratórios e centros de referência.

A proteína recombinante sHBsAg produzido neste trabalho, pelo sistema de expressão baseado em baculovírus e inseto e culturas de células de inseto, pode ser utilizada para produzir testes diagnósticos do tipo ELISA (EIA) diretos ou indiretos, quantitativos e qualitativos. A proteína recombinante sHBsAg pode ser fixada em placa de ELISA e servir de antígeno para ligação dos anticorpos presentes no soro dos pacientes infectados pelo HBV, ou, por meio da inoculação do sHBsAg recombinante em cobaias e produção de anticorpos, para serem usados no fundo do poço da placa de ELISA para detectar antígenos presentes no soro de pacientes infectados com o HBV. Takehara et al. (1988) em seu trabalho, produziu dois testes de ELISA utilizando a co-expressão das regiões inteiras dos genes $\mathrm{HBcAg}$ e HBsAg produzido pelo sistema de expressão em baculovírus, sob o comando do promotor da poliedrina. $O$ vírus com genes $\mathrm{HBcAg}$ e HBsAg expressou níveis elevados de $\mathrm{HBcAg}$ ( $40 \%$ das proteínas celulares) e níveis baixos do HBsAg ( $2 \%$ das proteínas celulares corados).

Como o HBV é um agente biológico de risco 3, com risco a saúde humana principalmente dos trabalhadores que ficam expostos ao vírus como, pesquisadores, agentes de saúde e todos os profissionais que participam dos 
estudos e produção de manufaturas como kits diagnóstico e vacinas, é preconizado pelo Parlamento Europeu e conselho da União Europeia $\left(7^{\circ}\right.$ diretiva especial nos termos do $n^{\circ} 1$ do artigo $16^{\circ}$ da diretiva 89/391/CEE) que devem ser sempre mantidas as atualizações de melhora e aperfeiçoamento da proteção da saúde e segurança dos trabalhadores por meio de manipulação de vírus recombinantes ou partículas virais mais seguros. O sistema de expressão em baculovírus também proporciona a criação de kits diagnóstico seguros, pois, o baculovírus não é patogênico para o homem, sendo ele incapaz de infectar células humanas, mesmo sendo capaz de transduzir células de mamíferos e fazer entrega gênica (van Oers, 2011; van Oers et al, 2015).

A construção do baculovírus recombinante vAcPHHB1, contendo o gene da região 'Small $S$ ' do antígeno HBsAg de HBV fusionado ao gene polh do baculovírus AcMNPV na sua região 3' foi bem sucedida. A análise da expressão da proteína recombinante em células de inseto infectadas mostrou que a proteína recombinante sHBsAg fusionada com a poliedrina do vírus AcMNPV, tanto amino-terminal quanto na carboxi-terminal está sendo produzida corretamente tanto in vitro como in vivo. Além disso, o teste feito utilizando corpos de oclusão purificados em gradiente de sacarose foram reconhecidos como antígenos pelos anticorpos comerciais Anti-HBsAg dos testes de imunoensaio (EIA) comerciais, observando ainda que a sHBsAg fusionado na região 5' do gene polh do AcMNPV (HBsPHs) apresentou níveis maiores de absorbância em relação a fusão na região 3' do polh (HBsPH1), podendo ser explicada pela razão que a região 3' do polh é essencial para montagem da poliedrina. Porém para uma melhor análise da proteína construída é necessário testar esta proteína contra soro de pacientes infectados com HBV e novos testes utilizando a técnica de ELISA com os anticorpos agora reconhecendo e diferenciando soro de pacientes infectados com Vírus da hepatite $A, B, C$ (HAV, HBV e HCV) e Citomegalovirus CMV. 


\section{Capítulo 3. Efeitos imunológicos de um peptídeo da glicoproteína do vírus da raiva pela estimulação de camundongo in vivo e in vitro}

\section{Introdução}

\section{A Raiva}

O vírus da raiva ou rabies virus (RABV) é um agente neurotrópico causador de encefalomielite em quase todas as espécies mamíferas, uma vez sintomáticos, a evolução nos animais e seres humanos é fatal (WHO, 2016). A Organização Mundial de Sanidade Animal estima que aproximadamente 70.000 pessoas morrem anualmente em decorrência da raiva em todo o mundo, predominantemente em países subdesenvolvidos. Os continentes com maiores índices de mortalidade de humana no mundo, são a Ásia e a África, representando $95 \%$ de casos fatais. Estas regiões são as que apresentam menores índices de controle de raiva canina no mundo (OIE, 2016).

Casos positivos de raiva humana causadas por mordedura de cães ainda acontecem na América Latina, com regiões consideradas críticas como Haiti, Peru, Honduras, República Dominicana, Guatemala, Bolívia e alguns Estados do Brasil, por exemplo: Maranhão, Piauí, Ceará e Mato Grosso do Sul (Vigilato et al, 2013; WHO, 2016). Contudo, a incidência de raiva canina e raiva humana transmitida por cães, diminuiu drasticamente nas últimas décadas na América Latina. Isto ocorreu graças aos intensos programas nacionais de controle da Raiva em vários países da América Latina a partir dos anos 80 , exemplificados pelas vacinações massivas em cães, profilaxia pré e pós-exposição, melhorias no diagnóstico da doença e vigilância intensiva (Vigilato et al, 2013).

O RABV pertence ao gênero Lyssavirus e família Rhabdoviridae, juntamente com as famílias Paramyxoviridae, Filoviridae e Bornaviridae, constituem a ordem Mononegavirales (ICTV, 2015). O RABV é um vírus com 
genoma RNA de fita simples, não segmentado com polaridade negativa e envelopado (Smith et al, 1996; Wunner, 2007). Por ser envelopado, o torna mais sensível a detergentes e solventes lipídicos como éter e clorofórmio, sendo assim muito baixa sua infectividade fora do hospedeiro (Dietzgen et al, 2012).

O vírion, que é a partícula completa do RABV, apresenta um formato de projétil, sendo constituído pela ribonucleoproteína (RNP) e pelo envelope viral que envolve a RNP (Dietzgen et al, 2012). O envelope viral é composto por uma bicamada lipídica à qual estão associadas a proteína $\mathrm{M}$ - Proteína Matriz e pela proteína G - Glicoproteína. A proteína M une o envelope do vírus à RNP interna e está envolvida na montagem e liberação viral (Mebatsion, 2001). A glicoproteína $\mathrm{G}$ é proteína mais imunogênica do RABV, sendo responsável pela produção de anticorpos neutralizantes, especialmente por sua região externa ao envelope, denominada domínio antigênico ou ectodomínio, além de importante papel na adsorção viral a receptores específicos nas células do hospedeiro (Wunner, 2007). A glicoproteína G é ainda capaz de estimular, em conjunto com as proteínas $\mathrm{N}$ e $\mathrm{P}$, células $\mathrm{T}$ auxiliares e citotóxicas, gerando uma resposta imune celular, além de participar do processo de brotamento de novos vírions (Kawano et al, 1990; Tordo et al, 1988). A expressão da glicoproteína G parece estar associada à indução de apoptose e à inibição da atividade da proteína $\mathrm{N}$ no transporte axoplásmico, ou seja, quanto maior a expressão de G em determinada amostra viral, mais apoptose e maior inibição do transporte viral nos neurônios, resultando em menor patogenicidade (Morimoto et al, 1999).

A RNP apresenta-se sob a forma de um complexo helicoidal constituído de RNA de fita simples, sentido negativo, associado a uma proteína $\mathrm{N}$ Nucleoproteína e uma proteína $\mathrm{P}$ - Fosfoproteína, assim como a uma proteína $\mathrm{L}$ - do inglês Large - Proteína RNA-polimerase (Wunner et al, 1988). A proteína $\mathrm{N}$ está associada ao RNA viral, protegendo-o da ação de ribonucleases, sendo esta a mais conservada dentre as proteínas dos Lyssavirus (Tordo et al, 1986). Devido a esta característica importante, o gene da proteína $\mathrm{N}$ tem sido a mais utilizada para a detecção do vírus da raiva por RT-PCR (Wunner, 2007). A proteína $\mathrm{P}$ interage com as proteínas $\mathrm{N}$ e $\mathrm{L}$ e acredita-se que atue como co fator da RNA polimerase, sendo multifuncional, ligando-se a outras proteínas 
virais para auxiliar na replicação do genoma viral e interagir com fatores celulares, provavelmente na disseminação e patogênese viral (Mebatsion, 2001). A proteína $L$ possui função de RNA polimerase RNA dependente (Tordo et al, 1986).

As correlações filogenéticas e sorológicas contribuem para a formação de dois filogrupos principais dentro do gênero Lyssavirus. O filogrupo I inclui o Rabies virus (RABV), Duvenhage virus (DUVV), European bat lyssavirus - tipo 1 e tipo 2 (EBLV 1 e 2), Australian bat lyssavirus (ABLV), Aravan virus (ARAV), Khujand virus (KHUV), Irkut virus (IRKV) e Bokeloh bat lyssavirus (BBLV). O filogrupo II inclui Lagos bat virus (LBV), Mokola virus (MOKV) e Shimoni bat virus (SHIBV). Baseado nas características filogenéticas e sorológicas, o West Caucasian bat virus (WCBV) e Ikoma lyssavirus (IKOV) não podem ser incluídos em nenhum destes filogrupos (Banyard et al, 2013; ICTV, 2015). Em estudo realizado por Badrane et al. (2001) com camundongos, com o intuito de verificar as diferenças de patogenicidade e imunopatogenicidade entre as espécies do filogrupo I e do filogrupo II, demonstraram que os virus do filogrupo I são mais patogênicos quando comparados com os do filogrupo II.

No Brasil, o ciclo epidemiológico da raiva pode ser dividido didaticamente em quatro ciclos: urbano, rural, silvestres terrestre e aéreo, sendo que os reservatórios animais mais importantes são os morcegos da Ordem Carnivora e Chiroptera (Figura 1). No ciclo urbano, a principal fonte de infecção é o cão doméstico. No Brasil, o morcego é o principal responsável pela manutenção do ciclo silvestre. Outros reservatórios silvestres são: macaco, raposa, coiote, chacal, gato-do-mato, jaritataca, guaxinim e mangusto (Kotait et al, 2007). As principais formas de transmissão são por mordedura, arranhadura e lambedura, ou seja, por meio da saliva contaminada com o vírus (BRASIL, 2008b). 


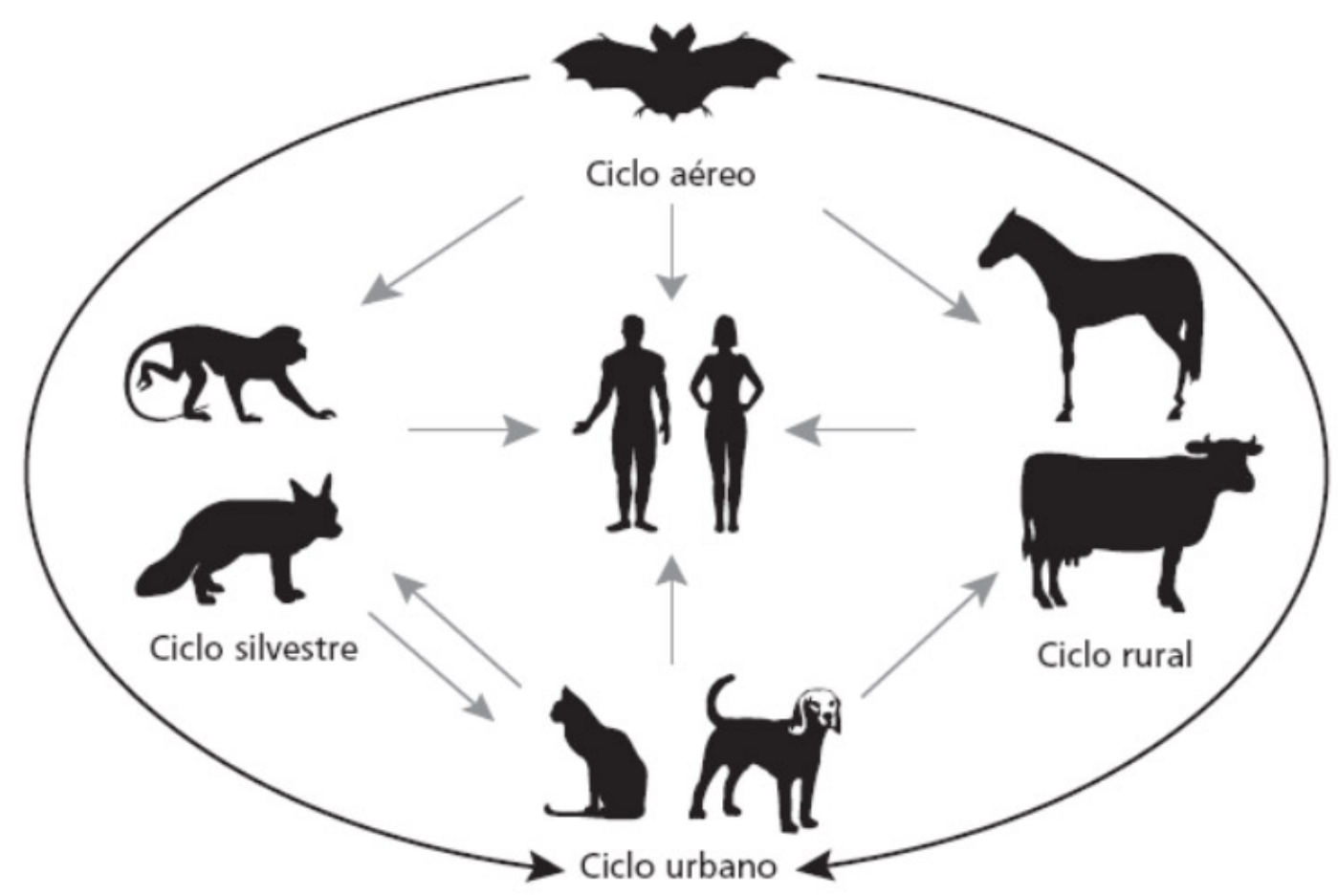

Figura 16. Ciclos epidemiológicos de transmissão da raiva no Brasil. Fonte: http://www.medicinanet.com.br/imagens/20090808142432.jpg

O painel de anticorpos monoclonais anti-nucleoproteína estabelecido pelo CDC (Centers for Disease Control - Atlanta - EUA), para estudos de isolados do RABV nas Américas, estabelecido por Diaz et al. (1994), demonstrou a existência de 12 variantes antigênicas, das quais 5 já foram identificadas no Brasil, que são: as variantes 1 e 2 com perfis antigênicos compatíveis com cães domésticos (Canis familiaris), variante 3 compatível com morcegos hematófagos Desmodus rotundus, variante 4 compatível com morcegos insetívoros Tadarida brasiliensis e variante 6 compatível com morcegos insetívoros Lasiurus cinereus. Foi encontrado também perfis não compatíveis com o painel de monoclonais préestabelecido para o estudo das estirpes isoladas nas Américas por Diaz et al. (1994), especialmente as variantes isoladas de sagui do tufo branco (Callithrix jacchus) e as de cachorro do mato (Cerdocyon thous) (Favoretto et al, 2002; Favoretto et al, 2006; Favoretto et al, 2001).

Diaz et al. (1994), demonstrou a existência de 12 variantes antigênicas de RABV nas Américas, das quais 5 já foram identificadas no Brasil, que são: as variantes 1 e 2 com perfis antigênicos compatíveis com cães domésticos (Canis familiaris), variante 3 compatível com morcegos hematófagos Desmodus 
rotundus, variante 4 compatível com morcegos insetívoros Tadarida brasiliensis e variante 6 compatível com morcegos insetívoros Lasiurus cinereus. Foram também encontrados perfis não compatíveis com o painel de monoclonais préestabelecido pelo CDC (Centers for Disease Control - Atlanta - EUA) e Diaz et al. (1994) para o estudo das estirpes isoladas nas Américas, tais como: variantes isoladas de sagui do tufo branco (Callithrix jacchus) e as de cachorro do mato (Cerdocyon thous) (Favoretto et al, 2002; Favoretto et al, 2006; Favoretto et al, 2001).

As manifestações clínicas da raiva podem ser bem diferentes nas espécies infectadas, desde de forma paralítica e furiosa (Dietzgen et al, 2012). As variantes virais do RABV, além de serem classificadas por suas características moleculares e antigênicas da nucleoproteína e da glicoproteína G, podem também ser identificadas de acordo com suas manifestações clínicas, origem geográfica e espécie de hospedeiro reservatório. A manifestação da raiva furiosa é mais frequente em variantes do RABV encontrada em morcegos carnívoros domésticos e selvagens na região nordeste do Brasil (Carnieli et al, 2006). Já a raiva com sinais clínicos de paralisia é mais comum em isolados relacionados com morcegos hematófagos, que é prevalente em todas as regiões do Brasil (BRASIL, 2015; Carnieli et al, 2006; Favoretto et al, 2002).

Modelos experimentais com cangambás Mephitis mephitis, mimetizando o que ocorre na infecção natural, mostram que após inoculação intramuscular na extremidade dos membros posteriores, ocorre uma replicação extra neural do RABV no músculo localizado na porta de entrada (Charlton et al, 1997).

Foi observado em experimentos com modelos experimentais (gambásMephitis mephitis), que o RABV pode se replicar em células musculares próximo ao local de inoculação, antes de invadir o SNC, representando um passo primordial à invasão do sistema nervoso (Tsiang, 1993). Contudo, ocasionalmente pode ocorrer a entrada direta do vírus no SNC, sem replicação prévia em células musculares (Shankar et al, 1991). Uma vez infectando células neuronais, o RABV é conduzido aos nervos periféricos e através de transporte axoplásmico retrógrado, ao SNC, posteriormente, disseminando-se por todo o organismo (Tsiang, 1993). Antígenos virais já foram detectados em células da 
epiderme, folículos pilosos, retina, córnea, glândulas lacrimais, glândulas salivares, pulmões, músculo cardíaco, mucosa gástrica e intestinal, pâncreas, parênquima renal, glândulas adrenais, tecidos neuroepiteliais dos ureteres, bexiga e uretra (Charlton, 1994). O principal meio de disseminação do RABV na natureza é através da secreção das glândulas salivares (Iwasaki, 1991).

\section{Vacina anti-rábica}

A raiva humana pode ser prevenida por meio de vacinação disponibilizada gratuitamente por órgãos de saúde (WHO, 2016). A primeira vacina foi produzida a partir de passagens sucessivas em cérebro de coelhos (Pasteur, 1885; Pasteur et al, 1881; Pasteur et al, 1882). Essa vacina causava acidentes neurológicos em virtude da presença de mielina no cérebro de animais adultos (Horack, 1939; Sellers, 1947). Fuenzalida \& Palácios (1955) desenvolveram uma vacina produzida em cérebro de camundongos recém-nascidos, quando o cérebro ainda não apresenta níveis consideráveis de mielina, reduzindo os efeitos colaterais, e assim chamadas de vacinas de primeira geração. Posteriormente Koprowski \& Cox (1948) testaram vacinas produzidas em ovos embrionados, chamadas de segunda geração. Entretanto, estas vacinas apresentavam baixa antigênicidade e reações alérgicas decorrentes da presença de proteínas do ovo. Além do mais, essas vacinas não são livres de risco, pois apresentam partículas de vírus não inativados (Rupprecht et al, 2002).

Com a possibilidade de produção de vacinas de vírus atenuado ou inativados e expressão de antígenos virais pelos sistemas de expressão de proteínas heterólogas, novas vacinas contra raiva têm sido desenvolvidas (Cenna et al, 2008; Faber et al, 2009; Gupta et al, 2005; Loza-Rubio et al, 2007; Lyons et al, 2008).

Em 2008 o Instituto Butantan iniciou a produção da vacina Vero-IB, onde o vírus rábico fixo da cepa PV proveniente do Instituto Pasteur de Paris foi propagado em células Vero aderidas a microcarregadores e suplementadas com meio de cultura sem proteínas de origem animal. (Frazatti-Gallina et al, 2004). As suspensões virais obtidas são concentradas por ultra-filtração, purificadas por cromatografia de troca iônica e inativadas com $\beta$-propiolactona. Testes de 
controle de qualidade foram realizados e comprovados a eficiência e segurança desssa vacina.

\section{Vacinas e sistema imune}

A resposta imune está intimamente relaciona com a eficiência de uma vacina, dosada pela sua imugenicidade, quesito imprescindível para sua aprovação e liberação. A maioria das vacinas licenciadas, se baseia na indução de anticorpos, como por exemplo os anticorpos neutralizantes, para comprovar sua eficácia (Plotkin, 2001). Para o desenvolvimento e produção de vacinas contra o RABV, a WHO recomenda que seja realizado teste para a verificação dos títulos de anticorpos neutralizantes, determinados por soroneutralização em camundongos ou em células. Considera-se protetor, níveis de anticorpos neutralizantes maiores ou igual a $0,5 \mathrm{UI} / \mathrm{ml}$ (WHO, 2002).

Diante de todas estas considerações abordadas acima, a expressão de proteínas do RABV no sistema baculovírus $x$ células de insetos poderiam ser um umas execelenta alternativa para produção de insumos visando a estimulção do sistema imune e soroneutralização do RABV.

Bocca et al. (2013) estudando os baculovírus Autographa californica multiple nucleopolyhedrovirus (AcMNPV) e o Anticarsia gemmatalis multiple nucleopolyhedrovirus (AgMNPV), demonstraram proteínas derivadas desses vírus são capazes de estimular a fagocitose de leveduras por macrófagos e a produção de interferon-gama (IFN-y) por esplenócitos in vitro, aumentar a migração de linfócitos TDC8+ no pulmão de camundongos sadios, bem como a expressão de CXCR3 e a produção de óxido nítrico. Além disto, protéinas do AgMNPV são capazes de aumentar a produção de interleucina-12 (IL-12) e a proliferação celular de esplenócitos in vitro. Considerando tais propriedades imunogênicas dos baculovírus e sua capacidade limitada de infectar células de mamíferos, a sua utilização como vetor para expressar proteínas do vírus da raiva poderia contribuir para a ativação dos linfócitos $B$ e $T$, não sendo necessário a utilização de adjuvantes à vacina. Várias vacinas utilizando este sistema de expressão, baculovírus e células de inseto, tem sido eficaz e eficiente, como por exemplo a Flublok $₫\left(\right.$ Influenza), Cervarix ${ }^{\circ}$ (Papilomavirus 
humano), Provenge ${ }^{\circledR}$ (cancer prostata), e Ingelvac ${ }^{\circledR}$ Circoflex ${ }^{\mathrm{TM}}$ (circovirus suino) (Mena \& Kamen, 2011)

\section{Justificativa}

A raiva é uma zoonose quase sempre fatal, resultando anualmente em milhares de mortes humanas ao redor do mundo, principalmente nos países subdesenvolvidos. Atualmente, é uma doença prevenida pela profilaxia pre e pós exposição (PEP) por meio da administração combinada de uma vacina do vírus da raiva inativado e imunoglobulina do vírus da raiva (RIG), seja ela homóloga ou heteróloga.

Estudos prévios demonstraram que a glicoproteína G, presente no envelope viral, tem uma grande capacidade em induzir a produção de anticorpos neutralizantes e ativar as células do sistema imune, resultando em uma possível proteção contra a doença. Além disso, já se tem conhecimento sobre a região mínima dessa proteína que é responsável pelo maior reconhecimento do sistema imune.

Dessa forma, o presente trabalho propõe a expressão de um peptídeo imunogênico da glicoproteína $G$ (pept/G) utilizando o sistema em baculovírus através da fusão à proteína poliedrina, com a concomitante purificação em larga escala. A produção desse peptídeo pode ser utilizada na estimulação do sistema imune, e futuramente como uma possível alternativa na prevenção da infecção pelo vírus da raiva.

\section{Objetivo}

Expressar o peptídeo imunogênico do vírus da raiva fusionado a poliedrina de AcMNPV e avaliar o seu potencial antigênico em camundongos por inoculação subcutânea. 


\section{Materiais e Métodos}

\section{Vírus, células e insetos}

Os vírus Autographa californica multiple nucleopolyhedrovirus (AcMNPV) e o baculovírus recombinante VAcPH-RGPV (Barros, 2011), derivados do bacmídeo bMON14272 (Bac-to-Bac "Baculovirus Expression System", Invitrogen) foram utilizados nesse trabalho. Os vírus foram propagados em cultura de células Trichoplusia ni (BTI-Tn5B1-4 ou Tn5B) (Granados et al, 1994) e/ou larvas de Spodoptera frugiperda, no terceiro instar. Essas células foram mantidas em meio TC-100 (Gibco-BRL) com $10 \%$ de soro fetal bovino a $28{ }^{\circ} \mathrm{C}$ e as larvas a $25^{\circ} \mathrm{C}$, com dieta artificial (Greene et al, 1976).

Células de Escherichia coli DH10ß (Invitrogen) foram utilizadas como hospedeiras para maioria dos plasmídeos utilizados no presente trabalho. No entanto, experimentos envolvendo Bac-to-Bac "Baculovirus Expression System" (Invitrogen), foram utilizadas células Escherichia coli DH10Bac (Invitrogen).

\section{Obtenção e clonagem do pept/G}

Foram inseridos, por meio de iniciadores específicos (pept/G F e pept/G R) (Tabela 3), sítios para a enzima de restrição Nco l em ambas as extremidades do gene de interesse, de modo a permitir a fusão do pept/G na região 5' do gene polh, esses iniciadores paream na posição 690-702 do gene. As reações de PCR foram realizadas em termociclador marca Switft Max $\left(\mathrm{ESCO}_{\circledast}\right)$, analisadas por eletroforese em gel da agarose (Joseph \& David, 2001) e fotografadas em um fotodocumentador (Alfa Innotec). O fragmento de $126 \mathrm{pb}$ observado foi cortado do gel com auxílio de uma lâmina e purificado utilizando-se 'GFX PCR DNA and Gel Band Purification kit' (GE Healthcare). O fragmento purificado foi clonado no vetor $p \mathrm{Pem}^{\circledR}-\mathrm{T}$ easy (Promega) de acordo com instruções do fabricante. Posteriormente, o plasmídeo obtido foi sequenciado (Macrogen Inc., Coreia do Sul) usando iniciadores T7 e SP6 que se paream em regiões presentes no plasmídeo comercial usado. 
Tabela 2. Iniciadores utilizados no trabalho

\begin{tabular}{|l|l|}
\hline Iniciadores & Sequência de nucleotídeos $\left(\mathbf{5}^{\prime} \rightarrow \mathbf{3}^{\prime}\right)$ \\
\hline pept/G F & CCATGGGGGGATCCAGAGGCCTATATAAGTCTTTAAA \\
& AGGAGCTTGCAAACTCCAGTTATGTGGAGTTCTCGGA \\
& CTTA \\
\hline pept/G R & CCATGGGGCATGCTGATGTTTGCATCGAGACCCATGT \\
& TCCATCCATAAGTCTAAGTCCGAGAACTCCACATAACT \\
& GG \\
\hline M13-F & GCCAGGGTTTTCCCAGTCACGAC \\
\hline M13-R & CACAGGAAACAGCTATGACCATGATT \\
\hline
\end{tabular}

\section{Clonagem do pept/G na região 5' do gene da polh do} AcMNPV

Um plasmídeo doador, previamente construído, foi utilizado para clonagem do pept/G. Esse plasmídeo é derivado do vetor comercial pFastBac1® (Invitrogen), que permitem fusão de genes de interesse à região 5' do gene polh do AcMNPV (pFastBac1-6xHis-AcPH) (Araujo, 2011). Este vetor apresenta o gene polh com um sítio de restrição para Nco I e uma cauda de hexa-histidina em fase, ambos na região 5' do gene (Figura 18-B). O plasmídeo pGem-pept/G contendo o gene de interesse foi digerido com Nco l, submetido a separação por eletroforese em gel de agarose e a banda correspondente ao gene de interesse foi purificada, como descrito anteriormente e utilizada para clonagem no plasmídeo doador $\mathrm{pFastBac1-6xHis-AcPH}$ previamente digeridos com a mesma enzima e defosforilado (Green \& Sambrook, 2012). O plasmídeo resultante foi confirmado por PCR com iniciadores específicos, por digestão e sequenciamento (Macrogen, Coreia do Sul).

\section{Obtenção de baculovírus recombinante para expressão do $\mathrm{pept} / \mathrm{G}$ fusionada à poliedrina}

O plasmídeo de fusão gerado contendo o gene quimérico (genes de interesse fusionados na região 5' do gene polh) foi utilizado para construção de baculovírus recombinante via sistema Bac-to-Bac (Invitrogen), conforme instruções do fabricante. 


\section{Produção in vitro da proteína quimérica pept/G}

\section{fusionada à poliedrina}

Uma $\mu \mathrm{g}$ do DNA plasmidial dos bacmídeos recombinantes gerados, foram utilizados para transfectar $10^{6}$ células de inseto Tn5B. Foi adicionado um volume de $10 \mu \mathrm{L}$ de DNA plasmidial dos bacmideos $(1 \mu \mathrm{g})$ em $90 \mu \mathrm{L}$ de meio de cultura TC-100 sem soro em placas de $35 \mathrm{~mm}$ e misturado, posteriormente foi adicionado $6 \mu \mathrm{L}$ de lipossomos catiônico da marca FuGENE® HD Transfection Reagent (Promega). A mistura contendo os lipossomos/DNA de cada bacmídeo foram misturados e incubados por 15 min à temperatura ambiente.

Placas com $10^{6}$ células em dois $\mathrm{mL}$ de meio TC-100 (HiMedia) foram incubadas com a mistura lipossomos/DNA de cada bacmídeo por 4 horas a $28^{\circ} \mathrm{C}$. Após $4 \mathrm{~h}$, a placa foi recomposta com mais dois $\mathrm{mL}$ de meio de cultura TC-100 contendo $10 \%$ de soro fetal bovino e incubada a $28^{\circ} \mathrm{C}$ por sete dias. As células de inseto que foram transfectadas com o DNA do baculovírus recombinante foram capazes de produzir vírus, pois como é sabido que o DNA nu do baculovírus é infectivo (Burand et al, 1980). Em uma nova placa de $100 \mathrm{~mm}$, contendo $5 \times 10^{6}$ células de inseto Tn5B foram adicionados $500 \mu \mathrm{L}$ do sobrenadante da transfecção e a placa incubada a $28^{\circ} \mathrm{C}$ por sete dias para amplificação dos vírus recombinantes. O DNA viral foi purificado pelo método de mini preparação como descrito por (O'Reilly et al, 1994). O DNA extraído foi utilizado para confirmação por meio de uma reação de PCR para o gene heterólogo.

\section{Analises da expressão da proteína recombinante em células de inseto e análise ultraestrutural de possíveis cristais recombinantes}

Monocamadas de células Tn5B (aproximadamente $10^{5}$ células) foram incubadas com moi de 10 vírus/célula com os vírus recombinantes. As células infectadas foram observadas e fotografadas a $72 \mathrm{~h} \mathrm{p}$.i. em um microscópio de luz invertida Axiovert 100 (Zeiss). Para microscopia eletrônica de varredura (MEV), aproximadamente $10 \mu \mathrm{l}$ do sobrenadante de células Tn5B (96 h p.i.) 
infectadas com o vírus recombinantes ( $10^{6}$ virus em forma de fenótipo BV) foram injetados em larvas de Spodoptera frugiperda quarto instar, no segundo par de falsas patas por meio de de uma agulha e seringa de $1 \mathrm{~mL}$. As larvas foram separadas individualmente para que não houvesse canibalismo e alimentadas com dieta artificial preparada segundo (Hoffmann-Campo et al, 2003). Após 5 dias, as larvas já apresentavam estágio avançado de infecção, tais como perda do apetite, clareamento da epiderme devido ao acúmulo de vírus nos núcleos das células epidermais e adiposas, parada no desenvolvimento larval e letargia (Federici, 1997). No sexto dia pós-infecção, as larvas estavam mortas ou em processo de morte. Após a morte, os cadáveres foram homogeneizados com o mesmo volume de PBS $(p / v)$, filtrado com gaze e centrifugado a $7.000 \times g$ por 10 min. O sobrenadante foi descartado e o sedimento ("pellet") ressuspendido em um volume de $5 \%$ Triton X-100 e centrifugado a $7,000 \times g$ por 10 min (duas vezes). O último "pellet" foi ressuspendido em $0,5 \mathrm{M} \mathrm{NaCl}$, centrifugado como descrito acima, e resuspendido com PBS. Todas as soluções continham inibidor de protease que inibe serina, cisteína e metaloproteases (Protease Inhibitor Cocktail -Sigma). As soluções ressuspendidas foram colocadas em um gradiente descontinuo de sacarose $(40-80 \%$ de sacarose em Phosphate Buffered Saline [PBS], 137,0 mM NaCl, 2,7 mM KCl, 10,0 mM Na2HPO4, 2,0 mM KH2PO4, pH $7,4)$ e centrifugada a $130.000 \times \mathrm{g}$ por $75 \mathrm{~min}$. As bandas que continham os possíveis cristais foram removidas do gradiente, diluídas em ddH2O, e centrifugadas a $7.000 \times$ g por $10 \mathrm{~min}$, o "pellet" foi ressuspendido em um $\mathrm{mL}$ de PBS. Posteriormente, as amostras foram desidratadas com acetona para serem secas ao ponto crítico (Balzer CPD30) e cobertas com ouro no aparelho "sputter coater" (Balzer SCD 050). As amostras foram, então, analisadas no microscópio de varredura JEOL JSM 840 a10 kV. 


\section{Análise da expressão das proteínas recombinantes em larvas de Spodoptera frugiperda e em cultura de células de insetos}

Uma alíquota de $10 \mu \mathrm{L}$ dos possíveis cristais purificados descritos caima foram analisados por eletroforese em dois géis desnaturantes de poliacrilamida (SDS-PAGE) a 12\% (Green \& Sambrook, 2012). Um dos géis foi corado e fixado em solução de $40 \%$ de metanol e $10 \%$ de ácido acético e azul de Coomassie $0,1 \%$, por cerca de 16 h e descorado em solução de $40 \%$ de metanol e $10 \%$ de ácido acético por $4 \mathrm{~h}$, sob leve agitação. O outro foi utilizado para transferência das proteínas para uma membrana de Nitrocelulose (GE Healthcare), para o experimento de imuno-detecção de proteínas ("Western-blot") abaixo descrito. As proteínas foram transferidas para membrana de Nitrocelulose, usando-se o aparato de transferência da Bio-Rad (Trans-Blot@ SD - Semi Dry Transfer Cell, para transferência semi-seca), de acordo com o protocolo do fabricante e com tampão de transferência Bjerrum and Schafer-Nielsen (48 mM de Tris; 39 mM de glicina; 20 \% metanol, $\mathrm{pH}$ 9,2). Após a transferência a membrana foi bloqueada com solução de PBS 1 X e $3 \%$ de leite em pó desnatado por $16 \mathrm{~h}$ a $4^{\circ} \mathrm{C}$, sendo em seguida processada para a imuno-marcação. O primeiro passo foi lavar a membrana por 3 vezes com PBS Tween (0,05 \%) para retirar toda a solução de bloqueio e em seguida colocar a membrana em uma solução de PBS/albumina bovina (BSA) 0,5 \% adicionada do anticorpo primário anti-6xHIS (GE Healthcare) de coelho por $1 \mathrm{~h}$. Essa solução foi então descartada e a membrana lavada novamente por 3 vezes em PBS Tween (0,05 \%) sob agitação suave. A seguir, a membrana foi colocada em uma solução de PBS/BSA 0,5 \% contendo o anti$\lg \mathrm{G}$ de coelho conjugado à enzima fosfatase alcalina (Sigma) por mais uma $1 \mathrm{~h}$ sob agitação suave. Esta solução então foi retirada e a membrana é lavada novamente com PBS Tween (0,05\%) por 3 vezes e com o tampão da enzima fosfatase alcalina por 5 min com agitação suave. O revelador, uma solução de NBT/BCIP (Promega), foi adicionado logo a seguir. A combinação de NBT (cloreto de tetrazólio nitro-azul) e BCIP (sal de 5-bromo-4-cloro-3'-p-toluidina indolil fosfato) produz um precipitado insolúvel de cor negro-púrpura intensa quando reage com fosfatase alcalina, que é uma popular enzima conjugada para 
sondas de anticorpo. A reação precisa ser interrompida com sucessivas lavagens com água destilada para que não ocorra marcação inespecífica.

\section{Imunização, produção de anticorpos e citocinas in vivo}

Corpos de oclusão do baculovírus AcMNPV (OBs) e os possíveis cristais da proteína recombinante fusionada com a POLH de AcMNPV foram incubados

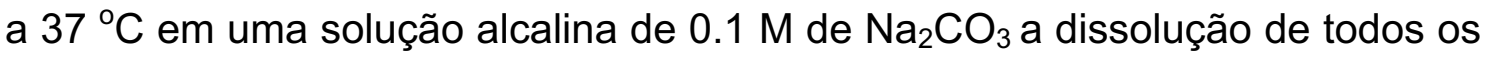
cristais, neutralizados com $0.1 \mathrm{M}$ de Tris- $\mathrm{HCl}(\mathrm{pH} 7.6)$, e submetidos a quantificação de proteina total utilizando Quant-iT ${ }^{\mathrm{TM}}$ assay kit (Thermo Scientific) seguindo as instruções do fabricante. Os OBs e os cristais recombinantes, foram utilizados para imunização em camundongos Balb/c, de 6-8 semanas de idade, por via subcutânea. Esses animais foram imunizados 3 vezes, com intervalos de 15 dias entre cada imunização. A proteína foi ministrada na concentração de $100 \mu \mathrm{g}$ em um volume final de $200 \mu \mathrm{L}$. A primeira inoculação foi ministrada com adjuvante incompleto de Freund (Sigma Aldrich) na proporção de 1:1, a segunda e a terceira imunização foi ministrada somente com os cristais. Os camundongos foram divididos em três grupos (6 animais por grupo): I - camundongo tratado com tampão fosfato, com grupo controle (grupo PBS); II- camundongo tratado com três doses dos possíveis cristais de proteína recombinante, com intervalos de duas semanas (grupo pept/G-polh); III - tratado com três doses de OBs de AcMNPV com intervalo de duas semanas (grupo POLH-Ac). Após 15 dias da última imunização, os camundongos foram sacrificados e o sangue periférico foi obtido por via retrorbital para obtenção do soro afim de dosar citocinas e anticorpos. A cavidade peritoneal destes animais foi ainda lavada para análise da migração celular no local, por meio de da contagem diferencial das células. $O$ soro foi armazenado a $-80^{\circ} \mathrm{C}$ até serem testados por Elisa, como descrito anteriormente. Paralelamente camundongos Balb/c, de 6-8 semanas de idade foram imunizados com o virus da raiva atenuado (vacina comercializada) para produção de anticorpo. 


\section{Ensaios de cultivo e proliferação de esplenócitos}

Os linfócitos foram separados por meio de maceração e lavagem do baço dos camundongos, marcados com CFSE, colocados em cultura por $48-60 \mathrm{~h}$, a $37^{\circ} \mathrm{C}$ e $5 \%$ de $\mathrm{CO}_{2}$ e depois o sobrenadante recolhido e suas células analisadas por citometria de fluxo. Os dados foram avaliados por meio do programa FlowJo versão 8.7 (TreeStar Software). As células em cultura foram estimuladas com Concanavalina A, para uma estimulação não específica $(5 \mu \mathrm{g} / \mathrm{mL})$, e com a proteína recombinante purificada $(100 \mu \mathrm{g} / \mathrm{mL})$ para as estimulações específicas. Esplenócitos totais obtidos do baço de camundongos BALB/c foram marcados com o marcador citoplasmático fluorescente 5,6-carboxifluoresceína diacetate succinimidil éster (CFSE, Invitrogen) a $5 \mu \mathrm{M}$ e transferidos para placas de poliestireno a $10^{6}$ células $/ \mathrm{ml}$ em meio RPMl 1640 (Sigma) enriquecido a 10\% de soro fetal bovino ( $\mathrm{v} / \mathrm{v})$ (Gibco), $1 \mathrm{mM}$ de aminoácidos não essenciais, $1 \mathrm{mM}$ de piruvato de sódio, $2 \mathrm{mM}$ de L-glutamina, $50 \mathrm{uM}$ de $2 \beta$-mercaptoetanol e $50 \mu \mathrm{g} / \mathrm{ml}$ de gentamicina. Posteriormente, foram adicionados aos poços da referida placa a proteína POLH-AcMNPV $(100 \mu \mathrm{g} / \mathrm{mL})$, RGPV/PEP $(100 \mu \mathrm{g} / \mathrm{mL})$, concanavalina A (ConA) (Sigma) a 4ug/mL (mitógeno inespecífico de linfócitos $\mathrm{T}$, utilizado como controle positivo) e meio enriquecido (controle negativo).

Após 5 dias de cultivo a $37^{\circ} \mathrm{C}$, em atmosfera de $5 \%$ de $\mathrm{CO}_{2}$, o sobrenadante de cultivo foi coletado, congelado a $-20^{\circ} \mathrm{C}$ e reservado para a quantificação de citocinas. As células foram lavadas 2 vezes com tampão de lavagem/leitura PBS contendo $2 \%$ de soro fetal bovino $(\mathrm{v} / \mathrm{v})$, ressuspendidas nesta mesma solução, adquiridas em citômetro de fluxo (BD FACS Verse) e lidas utilizando o programa BD CELLQUEST Pro. Os dados obtidos foram analisados pelo programa FlowJo versão 8.7 para a determinação da porcentagem de células que sofreram divisão e para a representação gráfica dos resultados. Essa porcentagem é calculada por meio da mensuração da quantidade relativa de células que apresentaram decaimento da fluorescência do CFSE (em comparação ao grupo controle negativo), que ocorre quando da ativação e expansão clonal dos linfócitos, visto que, como agente que se liga a proteínas intracelulares, o marcador tem seu sinal igualmente dividido durante a mitose celular. 


\section{Dosagem de citocinas}

O sobrenadante obtido dos ensaios de cultura celular 24,48 e $60 \mathrm{~h}$ foram submetidos à técnica de ELISA (Enzyme-Linked Immunosorbet Assay; Ensaio de Ligação Imunoenzimático) a fim de se avaliar os níveis de citocinas presentes nas amostras, demonstrados em valores absolutos (pg/ml). Foram utilizados kits comerciais (kit Ready-Set-Go!; eBioscience), seguindo-se as recomendações dos fabricantes, para a dosagem de TNF- $\alpha$, INF- $\gamma$ e IL10.

\section{Resultados}

\section{Obtenção e clonagem do pept/G}

A fim de expressar uma proteína quimérica contendo o pept/G fusionada à POLH do AcMNPV, um vetor doador, pFB1-6xHis-polh com modificações no gene polh foi construído (Figura 19). Esta ORF modificada tem um único sítio de restrição (Nco I) para fusão em fase de genes na região $5^{\prime}$ e seis histidinas para identificação da proteína recombinante por immunoblotting (Figura 18A-I e B). $O$ pept/G foi amplificado (Figura 18A-II e C) e inserido no gene polh modificado gerando o plasmídeo pFB1-6xHis-pept/G-polh (Figura 18A-III). O vetor modificado fusionado com pept/G foi denominado 6xHis-pept/G-polh (Figura 18D). Tanto o vetor sem a fusão e o vetor fusionado com o pept/G foram usados para construir os vírus recombinantes pelo Sistema Bac-to-Bac (Invitrogen). O vírus recombinante (denominado de vAc-pept/G-polh) foi amplificado em células de inseto. O DNA viral foi purificado e utilizado para confirmação por meio de de uma reação de PCR para o gene heterólogo utilizando iniciadores que paream no pept/G e amplificam um fragmento de aproximadamente $126 \mathrm{pb}$ (Figura 19). 
A

I
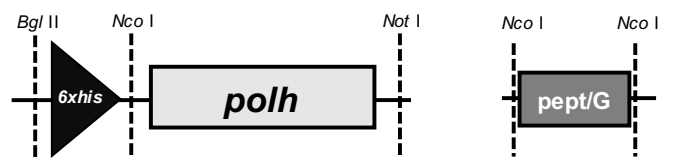

III

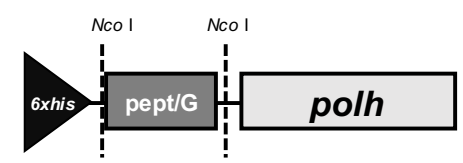

\title{
B
}

PFB1-6xHis-AcPH

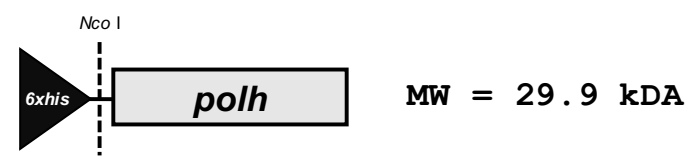

\begin{abstract}
MHHHHHHSMAMPDYTYRPTIGRTYVYDNKYYKNLGAVIKNAKRKKHFAEHE IEEATLDPLDNYLVAE DPFLGPGKNQKLTLFKE IRNVKPD TMKLVVGWKGKE FYRETWTRFMED SFP IVNDQEVMDVFLVVNM RPTRPNRCYKFLAQHALRCD PDYVPHDVIRIVEPSWVGSNNEYRISLAKKGGGCPIMNLHSEYTNSF EQFIDRVIWENFYKPIVYIGTDSAEEEEILLEVSLVFKVKEFAPDAPLFTGPAY
\end{abstract}

C

pept/G $\mathrm{MW}=4.8 \mathrm{kDA}$

RGLYKSLKGACKLQLCGVLGLRLMDGTWVSMQTS

D

pFB1-6xHis-pept/G-polh

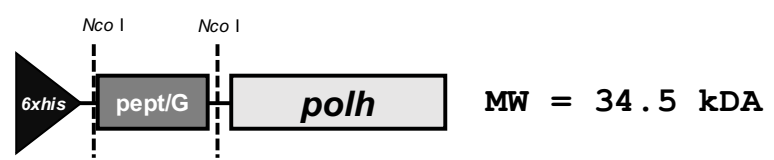

MHHHHHFSMGHADVCIETHVPSISLSPRTPHNWSLQAPFKDLYRPLDPPMAMPDYTYRPTIGRTYVY DNKYYKNLGAVIKNAKRKKHFAEHE IEEATLDPLDNYLVAEDPFLGPGKNQKLTLFKEIRNVKPDTM KLVVGWKGKEFYRETWTRFMEDSFPIVNDQEVMDVFLVVNMRPTRPNRCYKFLAQHALRCD PDYVPH DVIRIVEPSWVGSNNEYRISLAKKGGGCPIMNLHSEYTNSFEQFIDRVIWENFYKPIVY IGTDSAEE EEILLEVSLVFKVKEFAPDAPLFTGPAY

Figura 17. Esquemas dos genes usados para fusão da polh com o pept/G e sequências de aminoácidos deduzidas a partir da sequência do DNA. (A) Esquema mostrando a fusão do gene referente ao pept/G e o gene polh de AcMNPV. (I) Região do vetor pFB1-6xHis-polh usado para clonagem do gene de interesse no sítio para a enzima Nco I, resultando na fusão dos genes (II e III). Esse vetor recombinante foiusado para construir o vírus recombinante vAc-6xHis-pept/Gpolh por transposição sitio especifica em E. coli (Bac-to-bac® system, Invitrogen). (B) Sequência de aminoácidos deduzidos do pFB1-6xhis-polh e 6xHis-Polh (29.9 kDa), (C) pept/G (4.8 kDa), e (D) pFB1-6xHis-pept/G-polh (34.5 kDa). 


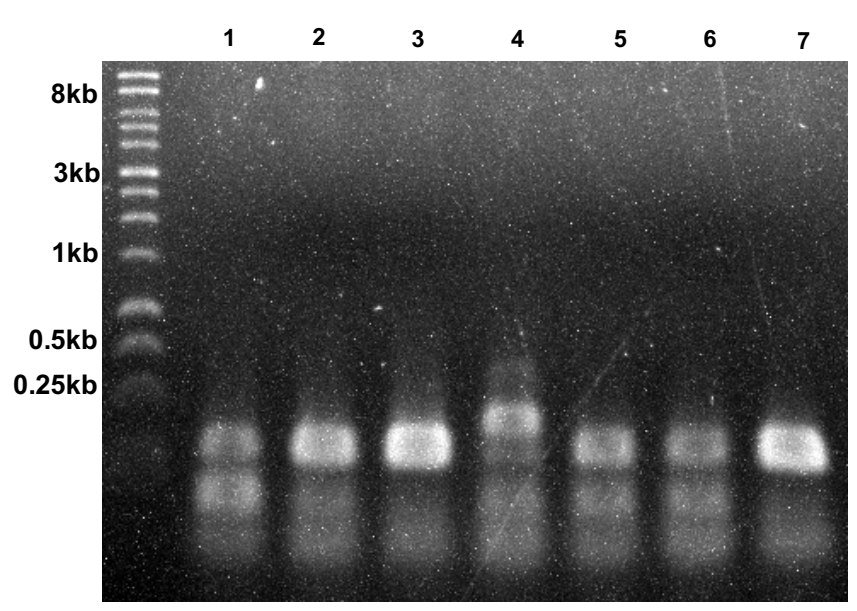

Figura 18. Confirmação da construção do vírus vAc-pept/G-polh. Gel de agarose a $0,8 \%$ mostrando resultado de reações de PCR a partir de DNA de possíveis vírus recombinantes contendo o gene pept/G em seu genoma. O resultado da PCR utilizando oligonucelotídeos (pept/G F e pept/G R) que amplificam um fragmento de tamanho de $126 \mathrm{pb}$.

\section{Análise da expressão da proteína recombinante}

Células Tn5B foram infectadas com diferentes vírus recombinantes e a 72 h p.i, foram analisadas por microscopia de luz (Figura 20), coletadas e o extrato protéico analisado por SDS-PAGE a $12 \%$ e imuno-marcação após a transferência das proteínas para uma membrana de nitrocelulose. As proteínas recombinantes contendo uma cauda de seis histidinas foram detectadas usando anticorpo anti-hexa-histidina (anti-6xHis) e nenhuma banda foi detectada em células não infectadas (Figura 21). 


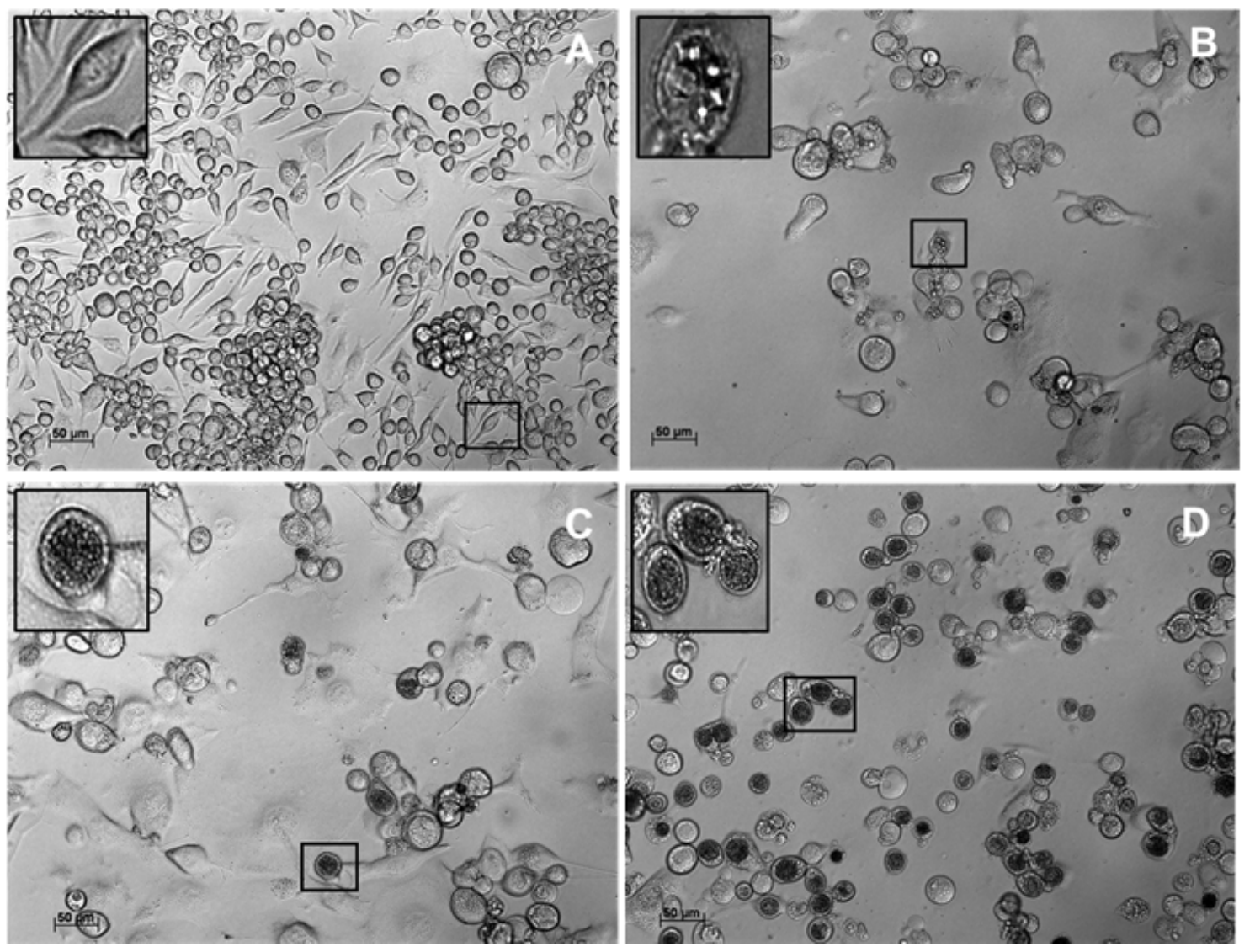

Figura 19. Análise do efeito citopático da infecção de células Tn5B com diferentes baculovírus a 72h.p.i. Células de inseto Tn5B não infectadas (A) ou infectadas ( $B, C$ e D) com diferentes recombinantes ou vírus selvagem. Células infectadas com o vírus AcMNPV (B); com vAc-6xhispolh (C) e vAc-pept/G-polh (D). OBs ou poliedros são mostrados no núcleo das células $B$ e corpos de oclusão de morfologia disforme e em agregados C, D e E. vAc-6xhis-polh virus contendo o gene polh contendo seis histidinas na 5 '. 


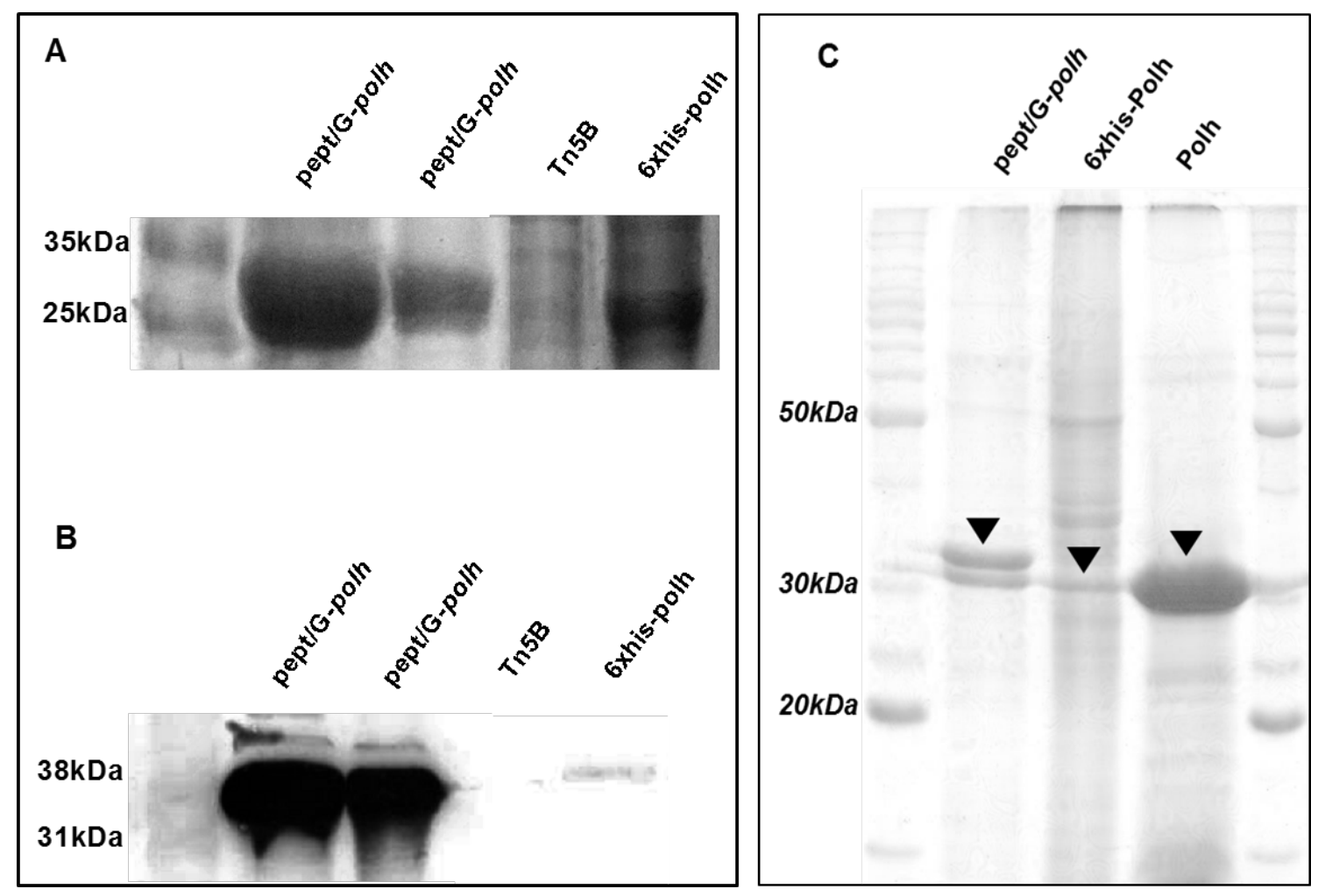

Figura 20. Análise da expressão de proteínas recombinantes em células de inseto infectadas com diferentes baculovírus recombinantes. (A e C) SDSPAGE $12 \%$ de extratos de células de inseto infectadas por baculovírus recombinantes. (B) Análise de Western blot dos extratos proteicos. A membrana foi imunomarcada com anti-6xHIS (Promega) como anticorpo primário. A mesma banda de $34,5 \mathrm{kDa}$ do SDS-PAGE gel é observada na membrana, que foi reconhecida pelo anticorpo anti-HIS.

\section{Análise da purificação dos cristais recombinantes}

Larvas de $S$. frugiperda foram infectadas com os vírus vAc-6xHis-polh e vAcPEP/polh e os cristais das proteínas recombinantes foram purificados e analisados por microscopia eletrônica de varredura (MEV), SDS-PAGE e immunoblotting. Os cristais apresentaram duas bandas após a centrifugação em gradiente de sacarose (Figure 22A). Na análise por MEV, os cristais se mostraram como uma massa proteíca sem forma definida e (Figura 19B-I e 19BII). Os cristais foram analisados por SDS-PAGE e imuno-marcação confirmando a natureza proteíca dos cristais e a presença da cauda de histina na imunomarcação com o anti-6xHis (Figura 23A), pept/G utilizando anticorpo anti-virus da raiva atenuado (vacina comercializada) (Figura 23B), PEP/Polh na imunomarcação com anti-PEP/Polh e anti-Polh (Figura 23C e D, respectivamente). 


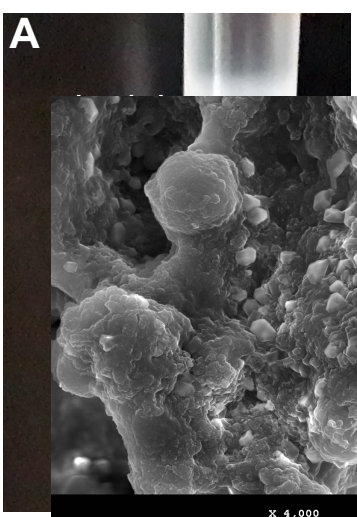

B
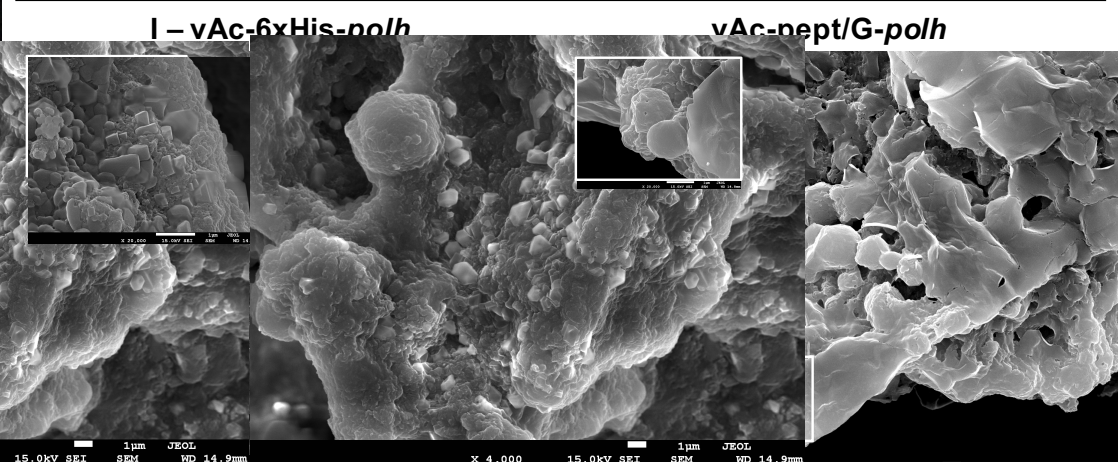

Figura 21. Purificação e analise ultraestrutural dos corpos de oclusão derivados de insetos infectados pelos baculovírus recombinantes vAc-6xHis-polh e vAcPEP/polh. Possíveis cristais da proteína POLH contendo seis histidinas na sua amino-terminal (derivados da infecção pelo vírus vAc-6xHis-polh) e da protéina POLH fusionada com o pept/G na amino-terminal (derivados da infecção pelo vírus vAc-pept/G-polh) purificados por centrifugação em gradiente de sacarose a partir de cadáveres $S$. frugiperda. (A) Um tubo de ultra centrífuga depois da centrifugação do extrato de insetos infectados com vAc-pept/G-polh, mostrando duas bandas. (B) Os cristais foram coletados do gradiente de sacarose e preparados para microscopia eletrônica de varredura: (I) Corpos de oclusão de cadáveres de inseto infectados com $6 x \mathrm{His}-P o l h$; (II) Corpos de cadáveres de inseto infectados com vAc-pept/G-polh (barra $=5 \mu \mathrm{m}$ ).
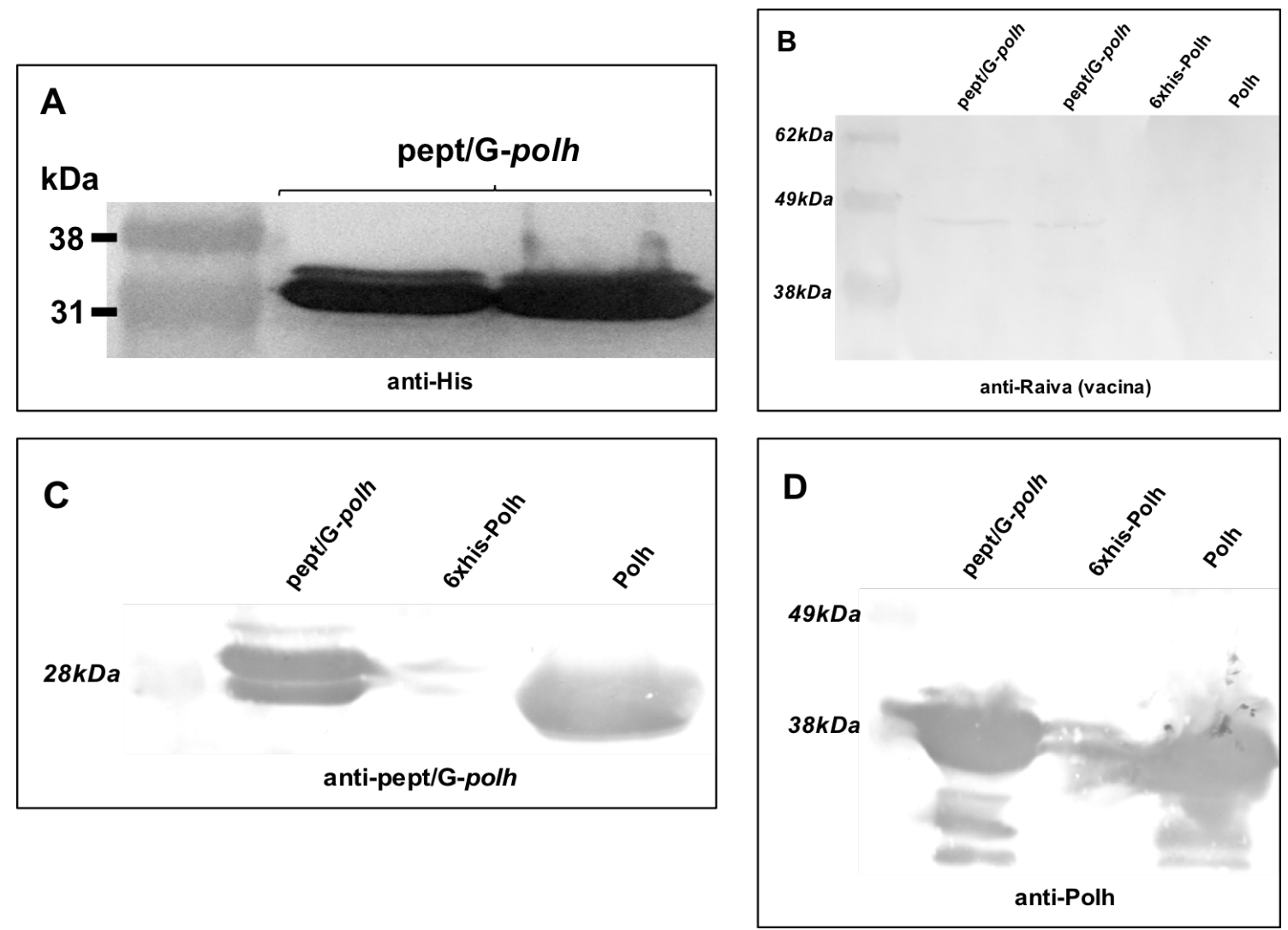

Figura 22. Análise da expressão de proteínas recombinantes. Cristais purificados e solubilizados derivados de insetos infectados com vírus recombinantes e separados por SDS-PAGE 12\% (dados não mostrados) foram transferidos para uma membrana de nitrocelulose. A membrana foi então tratada com anticorpos anti-6xHis (A) anti-virus da raiva atenuado (vacina comercializada) (B), anti-pept/G-polh (C) e anti-Polh (D). 


\section{Ensaio de proliferação celular e análises de citocinas}

Para analisar se as proteínas recombinantes produzidas em células de inseto infectadas por baculovírus recombinantes podem estimular linfócitos, células do baço de camundongos saudáveis foram estimuladas in vitro. Sobrenadantes de células do baço em cultura dos grupos experimentais foram utilizados para a detecção da produção de citocinas. As citocinas interleucina-10 (IL-10), fator de necrose tumoral (TNF- $\alpha$ ) e interferon-gama IFN- $\gamma$ ) foram medidos por ELISA. A estimulação com pept/G-polh não induziu a produção de IL-10, IFN-ץ e TNF- $\alpha$ em comparação aos níveis de células não estimuladas (dados não amostrados). Por outro lado, estimulou a proliferação de células do baço (Figura 24). Portanto, pept/G-polh estimulou eficientemente a proliferação de células do baço.
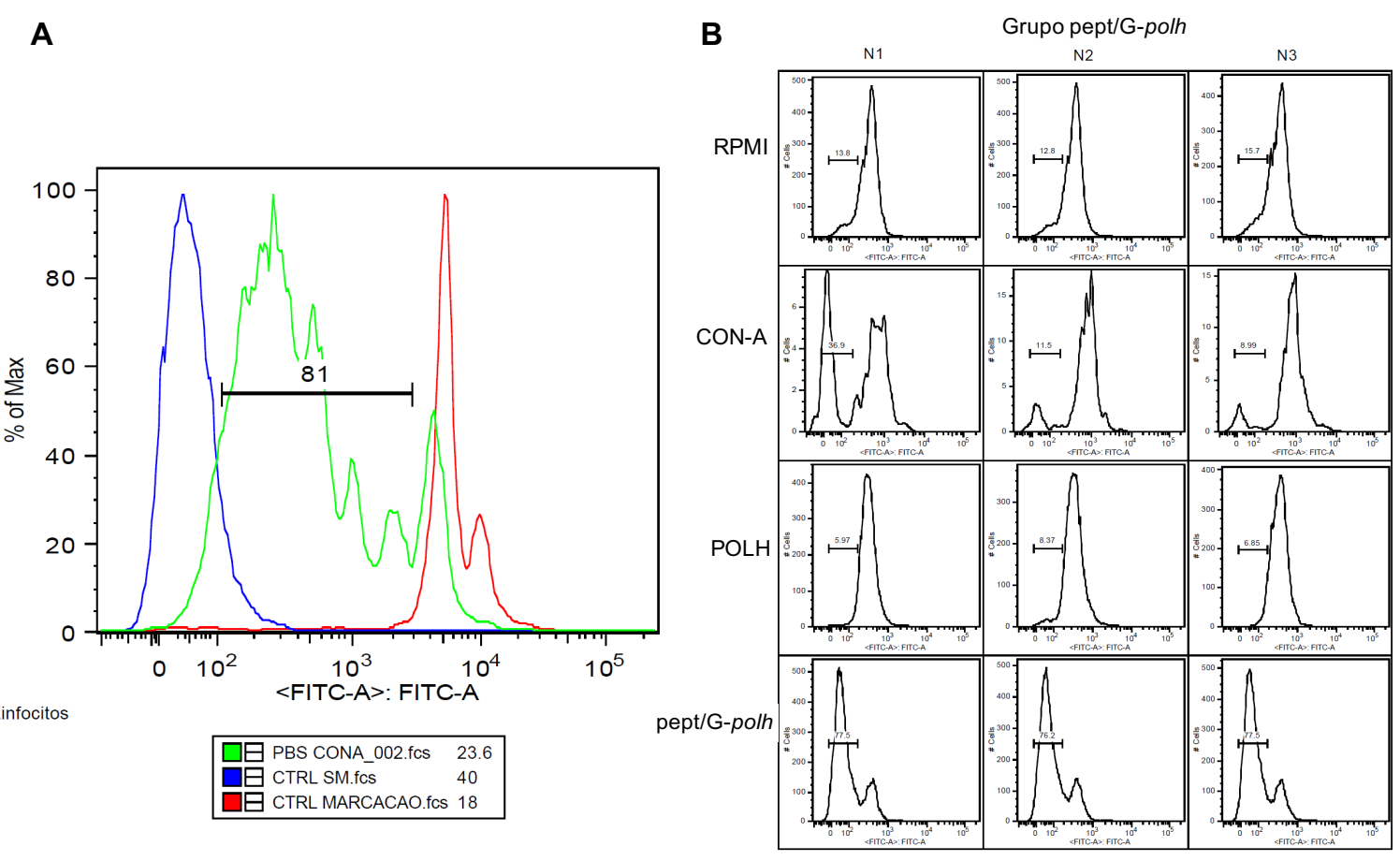

Figura 23. Ensaio de proliferação celular pelo método CFSE. A medida que a curva se desloca para a esquerda significa que está ocorrendo proliferação (A) Controle da técnica de CFSE. (B) experimento com o grupo de animais imunizados com pept/G-polh. Tampão fosfato com Concanavalina (PBS CONA_002fcs), controle sem marcação (CTRL_SM_fcs) e Controle marcado (CTRL_MARCAÇÃO). RPMI, Concanavalina A (CON-A), Poliedrina ÁcMNPV (POLH) e pept/G-polh. 


\section{Discussão}

Há mais de 20 anos, a expressão do gene da glicoproteína $\mathrm{G}$ tem sido estudada tanto em células eucarióticas (Burger et al, 1991; Kieny et al, 1984; McGarvey et al, 1995), quanto em procarióticas (Lathe et al, 1983). A proteína expressa em bactérias não teve efeito protetor em camundongos após desafio com o vírus da raiva, provavelmente porque a proteína produzida nesse sistema não foi glicosilada, o que é fundamental para que gere atividade. Diante disso, sistemas de expressão em células de mamíferos também foram testados. Morimoto et al. (1992) construíram um vetor derivado de retrovírus contendo o gene da GPV, expressando-a em células de neuroblastoma e BHK-21. Mochizuki et al. (1998) utilizaram HIV-1 (vírus da imunodeficiência humana) defectivo e também observaram produção da glicoproteína $G$ em células humanas HEK293-T (células embrionárias de rim humano). Em leveduras Saccharomyces cerevisiae, Klepfer et al. (1993), expressaram a glicoproteína G utilizando um vetor de expressão sob controle de um promotor indutível (metalotioneína) e um promotor constitutivo (triose desidrogenase). A glicoproteína $\mathrm{G}$ foi glicosilada e associada à membrana das leveduras, porém extratos de levedura contendo a proteína protegeram animais em desafio intramuscular, mas não no desafio intracerebral de camundongos.

Barros (2011) construiu um baculovírus recombinante contendo o gene da glicoproteína G fusionado à região 3' do gene da poliedrina, com o objetivo de facilitar a purificação das proteínas recombinantes. O baculovírus recombinante foi capaz de expressar a proteína recombinante em insetos infectados e os corpos de oclusão construídos foram purificados parcialmente por centrifugação em gradiente de sacarose. Entretanto, os corpos de oclusão não possuíam forma definida e não foi possível uma purificação livre de contaminantes.

Uma experimento com vacinação oral contra raiva em guaxinins, com glicoproteína G expressa por células Sf9 infectadas por baculovírus recombinante sob o comando do promotor polh, demonstrou que a glicoproteína $G$ expressa por células de inseto mostrou ser similar a glicoproteína $G$ nativa em relação a antigenicidade e imunogenicidade, quando vacinados com duas doses de vacina contendo $100 \mu \mathrm{g}$ de glicoproteína $\mathrm{G}$ na primeira dose e $200 \mu \mathrm{g}$ na segunda, depois de 7 semanas (Fu et al, 1993). 
A glicoproteína $G$ nativa tem uma grande capacidade em induzir a produção de anticorpos neutralizantes e ativação de células do sistema imune, tendo como resultado a proteção contra a doença, mesmo em um desafio intracerebral (Jallet et al, 1999; Lodmell et al, 2004; Perrin et al, 1985; Wiktor et al, 1984). Marissen et al. (2004) realizou experimentos com a tentativa de mapear a região mínima da glicoproteína $G$ que é reconhecida por anticorpos monoclonais, uma vez que algumas estirpes do vírus da raiva conseguem escapar da neutralização de dois anticorpos (Bakker et al, 2006). O gene da glicoproteína $G$ destas variantes anticorpo-resistentes foi sequenciado e resíduos críticos de aminoácidos envolvidos na ligação de cada um desses anticorpos foram identificados e testados por meio de análises de ligação, por meio do método "Pepscan" que se baseia em sintetizar vários peptídeos randômicos de alguma glicoproteína $G$ de interesse e que podem ser usados diretamente em Elisa, dado que estes peptídeos podem ser reconhecidos por anticorpos neutralizantes (Geysen et al, 1984; Miles et al, 1989; Slootstra et al, 1996).

Neste trabalho, a expressão de pept/G fusionados à proteína poliedrina dos baculovírus AcMNPV foi realizada. Possíveis corpos de inclusão foram purificados de larvas de $S$. frugiperda infectadas com os vírus recombnantes e analisados por microscopia eletrônica, SDS-PAGE e immunoblotting. Os corpos de inclusão apresentaram duas bandas no gradiente de sacarose, e um formato mais próximo do selvagem o que se espera de um peptídeo fusionado com a poliedrina de baculovírus, este resultado foi diferente do observado por Barros (2011), em que foi produzido apenas uma massa proteica.

Os possíveis OBs foram dissolvidos em solução alcalina e submetidos ao Western blot e uma banda imunorreativa de $34.5 \mathrm{kDa}$ foi detectada usando anti6xHis comprovando a expressão da proteína fusionada e usando o anticorpo anti-virus da raiva atenuado (vacina comercializada), anti-pept/G-Polh e antiPolh, comprovando a correta imunogenicidade.

A glicoproteína $\mathrm{G}$ possui epítopos que envolvem a ativação de linfócitos $T$ citotóxicos durante a infecção viral (Desmézières et al, 1999). Quando camundongos vacinados com glicoproteína $\mathrm{G}$ trimérica e solúvel, produzida por células HEK-293T, com e sem o adjuvante Matrix-M (adjuvante baseado em saponina que modula tanto resposta humoral quanto celular), apresentaram 
título de anticorpos neutralizantes de 1,99 e 12,56 Ul/mL, respectivamente, e sobrevivência de $100 \%$ em ambos os casos, demonstrou capacidade imunoprotetiva quando desafiados com o vírus da raiva intracerebralmente. Os animais vacinados com glicoproteína $\mathrm{G}$ monomérica, produzida por células Sf9 infectadas com baculovírus recombinante, também com $1 \mu \mathrm{g}$ de glicoproteína $\mathrm{G}$ /dose, com e sem o adjuvante, apresentaram título de anticorpos neutralizantes de 0,18 e $11,67 \mathrm{UI} / \mathrm{mL}$, e sobrevivência $10 \%$ e $80 \%$, respectivamente, quando desafiados com o vírus da raiva intracerebralmente. Vacinas inativadas e proteínas geralmente geram uma resposta imune, celular ou humoral, insuficientes, requerendo uma associação à adjuvantes que sejam capazes de induzir um resposta imunológica protetora (Vander Veen et al, 2012).

Trabalhos realizados com OBs de AgMNPV, mostraram que podem aumentar uma resposta de células Th1 e podem ser considerados mais eficazes como vetores de vacinação ou adjuvantes imunológicos do que AcMNPV (Bocca et al, 2013). AgMNPV na forma selvagem ou recombinante, pode ser também utilizado para alterar o tipo de resposta adaptativa desenvolvida (Barros, 2011; Bocca et al, 2013).

A produção de anticorpos e a resposta imune mediada por células são reconhecidamente importantes para a proteção contra a infecção pelo vírus da raiva (Chopy et al, 2011; Hooper et al, 1998; Saxena et al, 2009; Wen et al, 2011). A análise das citocinas permite avaliar a tendência da resposta imunológica estimulada por um determinado antígeno. Basicamente, por meio da proliferação de clones de células CD4+ Th1 e Th2 e do estudo da liberação de citocinas após estímulo com antígeno, é possível definir quais mecanismos imunológicos foram ativados contra o antígeno em estudo. Nesse contexto, quando utilizamos cristais recombinantes fusionado com o peptídeo mais imunogênico do vírus da raiva. Houve um aumento da proliferação celular, evidenciando uma resposta imune celular. A produção de IL-10, IFN-y e TNF- $\alpha$ está relacionada à resposta imune humoral, inibindo a ativação de Th1 ( $\mathrm{Ng} \&$ Oldstone, 2014). As citocinas produzidas por linfócitos Th1, como o IFN- $\gamma$, resultam na produção de anticorpos IgG2a, promovendo uma tendência a resposta imune do tipo celular, característica de uma infecção causada por vírus (Nimmerjahn \& Ravetch, 2005). Diante disto, analisamos a produção de algumas citocinas (IL-10, IFN-ץ e TNFa) por esplenócitos ex vivo, para melhor caracterizar a resposta imunológica dos 
animais imunizados com a proteína recombinante. Porém, não foi observada uma diferença significativa quando analisadas estatisticamente quanto a produção de IL-10, IFN-y e TNF- $\alpha$ em relação aos controles, quando utilizamos cristais pept/G-polh.

Os resultados deste trabalho corroboram outros trabalhos anteriores que mostraram que baculovírus recombinantes e as proteínas recombinantes expressas são capazes de modular a resposta imune de mamíferos in vivo e in vitro. Observamos que o pept/G-polh é capaz de estimular células do baço e desencadear uma resposta celular. Porém, será preciso padronizar melhor a análise de IL-10, IFN-y e TNF- $\alpha$, uma vez que não foi possível observar níveis diferentes do controle, como observado pelos trabalhos citados acima que utilizaram a glicoproteína $\mathrm{G}$ fusionada e não fusionada com a poliedrina.

Outros trabalhos serão necessários para elucidar se baculovírus selvagem ou formas recombinantes podem alterar os tipos de respostas imunológicas características de outras doenças.

\section{Perspectivas}

\section{Hepatite}

* Realizar um teste de ELISA onde a proteína produzida será utilizada como antígeno para reconhecer anticorpos presentes no soro de pacientes infectados com HBV, HAV, HCV e CMV.

* Redigir um artigo/patente com os resultados obtidos.

\section{Raiva}

Repetir o experimento de ativação de linfócitos B após a estimulação in vitro com $O$ baculovírus recombinante após a inoculação em camundongos saudáveis, para avaliação da expressão de moléculas coestimulatórias na superfície dos linfócitos $B$, por citometria de fluxo, produção de anticorpos e produção de citocinas, por ELISA. 
* Repetir o experimento de ativação de linfócitos T in vitro com o baculovírus recombinante pela análise da expressão de citocinas pelo método de Elisa, proliferação celular, citometria de fluxo e cooperação na ativação de linfócitos $B$.

* Avaliação da dinâmica da resposta imune por anticorpos após a inoculação em camundongos saudáveis do baculovírus recombinante por meio da soroneutralização;

* Análise de sobrevivência de camundongos vacinados com a proteina recombinante após o desafio com amostra padrão do vírus da raiva.

- Redigir um artigo com os resultados obtidos.

\section{Referências Bibliográficas}

Araujo ACOd (2011) Nova abordagem para expressão da partícula sSHbsAg do antígeno HBsAg do vírus da hepatite $B$ em células de inseto. Mestrado Thesis, Patologia Molecular da Universidade de Brasília, Universidade de Brasília.,

Arauz-Ruiz P, Norder H, Robertson BH, Magnius LO (2002) Genotype H: a new Amerindian genotype of hepatitis B virus revealed in Central America. Journal of general virology 83: 20592073

Ardisson-Araújo DMP, Morgado FDS, Schwartz EF, Corzo G, Ribeiro BM (2013a) A New theraphosid Spider Toxin Causes Early Insect Cell Death by Necrosis When Expressed In Vitro during Recombinant Baculovirus Infection. PloS one 8: 12

Ardisson-Araújo DMP, Rocha JR, da Costa MHO, Bocca AL, Dusi AN, de Oliveira Resende R, Ribeiro BM (2013b) A baculovirus-mediated strategy for full-length plant virus coat protein expression and purification. Virology journal 10: 262-262

Badrane H, Bahloul C, Perrin P, Tordo N (2001) Evidence of two Lyssavirus phylogroups with distinct pathogenicity and immunogenicity. Journal of virology 75: 3268-3276

Bakker AB, Marissen W, Goudsmit J. (2006) Antigenic peptides of rabies virus and uses thereof. Google Patents.

Banyard AC, Hayman D, Freuling CM, Müller T, Fooks AR, Johnson N (2013) Bat rabies. In Rabies: scientific basis of the disease and its management, pp 215-267. Elsevier Academic Press, Oxford, UK

Barros MCdES (2011) Atividade de baculovírus selvagens em camundongos in vivo e in vitro e Expressão da proteína do envelope do vírus da Febre Amarela (YFE) e da glicoproteína do vírus da Raiva (RVGP) em células de inseto. Universidade de Brasília, 
Barry GF (1988) A broad-host-range shuttle system for gene insertion into the chromosomes of Gram-negative bacteria. Gene 71: 75-84

Beck J, Nassal M (2007) Hepatitis B virus replication. World journal of gastroenterology 13: 48

Blissard GW (1996) Baculovirus--insect cell interactions. Cytotechnology 20: 73-93

Bocca AL, Barros MCdES, Martins GKM, de Araújo ACO, Souza MJ, Ribeiro AM, Figueiredo F, Ribeiro BM (2013) Immunological effects of Anticarsia gemmatalis multiple nucleopolyhedrovirus (AgMNPV) by stimulation of mice in vivo and in vitro. Virus research 176: 119-127

BRASIL. (2008a) Hepatites virais: o Brasil está atento. In Saúde Md (ed.), Brasilia, DF, Brasil.

BRASIL. (2008b) Manual de diagnóstico laboratorial de raiva. In Saúde Md (ed.), Brasilia, DF, Brasil.

BRASIL. (2015) Casos de raiva humana, grandes regiões e unidades federadas 1990 a 2015., Secretaria de Vigilância em Saúde, Vol. 2015.

Bruss V (2004) Envelopment of the hepatitis B virus nucleocapsid. Virus research 106: 199-209

Burand JP, Summers MD, Smith GE (1980) Transfection with baculovirus DNA. Virology 101: 286290

Burger S, Remaley A, Danley J, Moore J, Muschel R, Wunner W, Spitalnik S (1991) Stable expression of rabies virus glycoprotein in Chinese hamster ovary cells. Journal of general virology 72: 359-367

Carnieli P, Brandão PE, Carrieri ML, Castilho JG, Macedo Cl, Machado LM, Rangel N, de Carvalho RC, de Carvalho VA, Montebello L (2006) Molecular epidemiology of rabies virus strains isolated from wild canids in Northeastern Brazil. Virus research 120: 113-120

Carvalho AMCd, Araújo TMEd (2008) Análise da produção científica sobre Hepatite B na pósgraduação de enfermagem:[revisão]. Revista Brasileira de Enfermagem 61: 518-522

Cenna J, Tan GS, Papaneri AB, Dietzschold B, Schnell MJ, McGettigan JP (2008) Immune modulating effect by a phosphoprotein-deleted rabies virus vaccine vector expressing two copies of the rabies virus glycoprotein gene. Vaccine 26: 6405-6414

Charlton K (1994) The pathogenesis of rabies and other lyssaviral infections: recent studies. Current topics in microbiology and immunology 187: 95

Charlton K, Nadin-Davis S, Casey G, Wandeler A (1997) The long incubation period in rabies: delayed progression of infection in muscle at the site of exposure. Acta neuropathologica 94: 73-77

Chopy D, Detje CN, Lafage M, Kalinke U, Lafon M (2011) The type I interferon response bridles rabies virus infection and reduces pathogenicity. Journal of neurovirology 17: 353-367

Clem RJ, Passarelli AL (2013) Baculoviruses: Sophisticated Pathogens of Insects. PLoS Pathogens 9: e1003729-e1003729 
Condreay JP, Kost TA (2007) Baculovirus expression vectors for insect and mammalian cells. Current Drug Targets 8: 1126-1131

Custer B, Sullivan SD, Hazlet TK, lloeje U, Veenstra DL, Kowdley KV (2004) Global epidemiology of hepatitis B virus. Journal of clinical gastroenterology 38: S158-S168

da Silva AL, Vitorino RR, Esperidião-Antonio V, Santos ET, Santana LA, Henriques BD, Gomes AP (2012) Hepatites virais: B, C e D: atualização. Rev Bras Clin Med São Paulo 10: 206-218

Darani M, Gerber M (1974) Hepatitis-B antigen in vaginal secretions. The Lancet 304: 1008

Davison F, Alexander GJ, Trowbridge R, Fagan EA, Williams R (1987) Detection of hepatitis B virus DNA in spermatozoa, urine, saliva and leucocytes, of chronic HBsAg carriers: a lack of relationship with serum markers of replication. Journal of hepatology 4: 37-44

Desmézières E, Jacob Y, Saron M-F, Delpeyroux F, Tordo N, Perrin P (1999) Lyssavirus glycoproteins expressing immunologically potent foreign $B$ cell and cytotoxic $T$ lymphocyte epitopes as prototypes for multivalent vaccines. Journal of general virology 80: 2343-2351

Diaz AM, Papo S, Rodriguez A, Smith JS (1994) Antigenic Analysis of Rabies-virus Isolates from Latin America and the Caribbean. Journal of Veterinary Medicine, Series B 41: 153-160

Dietzgen R, Calisher C, Kurath G, Kuzman I, Rodriguez L, Stone D, Tesh R, Tordo N, Walker P, Wetzel T (2012) Rhabdoviridae, p 654-681. Virus taxonomy, Ninth Report of the International Committee on Taxonomy of Viruses Elsevier, San Diego, CA

El Khouri M, Santos VAd (2004) Hepatitis B: epidemiological, immunological, and serological considerations emphasizing mutation. Revista do Hospital das Clínicas 59: 216-224

Entwistle P.F. EHF (1985) In: Comprehensive Insect Physiology Biochemistry and Physiology. In Viral control, eds. Gilbert LI KG (ed), pp 347-412. Pergamon Press, Oxford, UK

Faber M, Li J, Kean RB, Hooper DC, Alugupalli KR, Dietzschold B (2009) Effective preexposure and postexposure prophylaxis of rabies with a highly attenuated recombinant rabies virus. Proceedings of the National Academy of Sciences 106: 11300-11305

Favoretto SR, Carrieri ML, Cunha EMS, Aguiar EA, Silva LHQ, SodrÉ MM, Souza MCA, Kotait I (2002) Antigenic typing of Brazilian rabies virus samples isolated from animals and humans, 1989-2000. Revista do Instituto de Medicina Tropical de Sao Paulo 44: 91-95

Favoretto SR, De Mattos CC, De Morais NB, Carrieri ML, Rolim BN, Silva LM, Rupprecht CE, Durigon EL, De Mattos CA (2006) Rabies virus maintained by dogs in humans and terrestrial wildlife, Ceara State, Brazil. Emerging Infectious Diseases 12: 1978-1981

Favoretto SR, de Mattos CC, Morais NB, Araújo FA, de Mattos CA (2001) Rabies in marmosets (Callithrix jacchus), Ceará, Brazil. Emerging Infectious Diseases 7: 1062

Federici BA (1997) Baculovirus pathogenesis. In The baculoviruses, pp 33-59. Springer

Ferreira CT, Silveira Td (2004) Hepatites virais: aspectos da epidemiologia e da prevenção. Revista brasileira de epidemiologia = Brazilian journal of epidemiology 7: 473-487 
Fonseca JCFd (2007) História natural da hepatite crônica B:[revisão]. Revista da Sociedade Brasileira de Medicina Tropical: 672-677

Frazatti-Gallina NM, Mourão-Fuches RM, Paoli RL, Silva ML, Miyaki C, Valentini EJ, Raw I, Higashi HG (2004) Vero-cell rabies vaccine produced using serum-free medium. Vaccine 23: 511-517

Friesen PD (1997) Regulation of baculovirus early gene expression. In The baculoviruses, pp 141170. Springer

Fu ZF, Rupprecht CE, Dietzschold B, Saikumar P, Niu HS, Babka I, Wunner WH, Koprowski H (1993) Oral vaccination of racoons (Procyon lotor) with baculovirus-expressed rabies virus glycoprotein. Vaccine 11: 925-928

Funk CJ, Braunagel SC, Rohrmann GF (1997) Baculovirus structure. In The baculoviruses, pp 732. Springer

Ganem D, Prince AM (2004) Hepatitis B virus infection-natural history and clinical consequences. New England Journal of Medicine 350: 1118-1129

Ganem D, Schneider RJ (2001) Hepadnaviridae: the viruses and their replication. Fields virology 2: $2923-2969$

Geysen HM, Meloen RH, Barteling SJ (1984) Use of peptide synthesis to probe viral antigens for epitopes to a resolution of a single amino acid. Proceedings of the National Academy of Sciences 81: 3998-4002

Gonçales Júnior FL (2002) Hepatite B: história natural da infecção; apresentação clínica; complicações. In Tratado de hepatites virais, pp 141-150. Atheneu

Gonçales N, Cavalheiro N (2006) Marcadores sorológicos da hepatite B e sua interpretação. Brazilian Journal of Infectious Diseases 10: 19-22

Granados RR, Guoxun L, Derksen ACG, McKenna KA (1994) A new insect cell line from Trichoplusia ni (BTI-Tn-5B1-4) susceptible to Trichoplusia ni single enveloped nuclear polyhedrosis virus. Journal of Invertebrate Pathology 64: 260-266

Granados RR, Lawler KA (1981) In vivo pathway of Autographa californica baculovirus invasion and infection. Virology 108: 297-308

Green M, Sambrook J (2012) Molecular cloning: a laboratory manual, Cold Spring Harbor Laboratory Press. New York

Greene GL, Leppla NC, Dickerson WA (1976) Velvetbean caterpillar: a rearing procedure and artificial medium. Journal of Economic Entomology 69: 487-488

Grob P (1998) Hepatitis B: virus, pathogenesis and treatment. Vaccine 16: S11-S16

Gupta PK, Sharma S, Walunj SS, Chaturvedi V, Raut AA, Patial S, Rai A, Pandey K, Saini M (2005) Immunogenic and antigenic properties of recombinant soluble glycoprotein of rabies virus. Veterinary microbiology 108: 207-214 
Haase S, Sciocco-Cap A, Romanowski V (2015) Baculovirus Insecticides in Latin America: Historical Overview, Current Status and Future Perspectives. Viruses 7: 2230-2267

Hadziyannis SJ, Vassilopoulos D (2001) Hepatitis B e antigen-negative chronic hepatitis B. Hepatology 34: 617-624

Hatzakis A, Magiorkinis E, Haida C (2006) HBV virological assessment. Journal of hepatology 44: S71-S76

Hawtin RE, Zarkowska T, Arnold K, Thomas CJ, Gooday GW, King LA, Kuzio JA, Possee RD (1997) Liquefaction of Autographa californica nucleopolyhedrovirus-infected insects is dependent on the integrity of virus-encoded chitinase and cathepsin genes. Virology 238: 243-253

Hegedus D, Erlandson M, Gillott C, Toprak U (2009) New Insights into Peritrophic Matrix Synthesis, Architecture, and Function. In Annual Review of Entomology Vol. 54, pp 285-302. Palo Alto: Annual Reviews

Herniou EA, Olszewski JA, O'Reilly DR, Cory JS (2004) Ancient coevolution of baculoviruses and their insect hosts. Journal of virology 78: 3244-3251

Hoffmann-Campo C, Oliveira L, Moscardi F, Gazzoni D, Corrêa-Ferreira B, Lorini I, Borges M, Panizzi A, Sosa-Gomez D, Corso I (2003) Integrated pest management in Brazil. Integrated pest management in the global arena CABI Publishing, Wallingford and Cambridge: 285-299

Hollinger FB (2008) Hepatitis B virus infection and transfusion medicine: science and the occult. Transfusion 48: 1001-1026

Hollinger FB, Liang TJ (2001) Hepatitis B virus. Fields virology 4: 2971-3036

Hoofnagle H (1983) Serodiagnosis of acute viral hepatitis. Hepatology 3: 267-268

Hooper DC, Morimoto K, Bette M, Weihe E, Koprowski H, Dietzschold B (1998) Collaboration of antibody and inflammation in clearance of rabies virus from the central nervous system. Journal of virology 72: 3711-3719

Horack HM (1939) Allergy as a factor in the development of reactions to anti-rabic treatment. The American Journal of the Medical Sciences 197: 672-682

Hourani MR, Mayor GH, Greenbaum DS, Hugget DO, Patterson MJ (1978) Hepatitis B surface antigen in urine of hemodialysis patients. Kidney international 13: 324-328

ICTV. (2015) INTERNAIONAL COMITTEE ON TAXONOMY OF VIRUSES., Vol. 2016.

Irwin GR, Allen AM, Bancroft WH, Karwacki JJ, Brown H, Pinkerton R, Willhight M, Top F (1975) Hepatitis $B$ antigen in saliva, urine, and stool. Infection and immunity 11: 142-145

Iwasaki Y (1991) Spread of virus within the central nervous system. The natural history of rabies: 121-132

Jallet C, Jacob Y, Bahloul C, Drings A, Desmezieres E, Tordo N, Perrin P (1999) Chimeric lyssavirus glycoproteins with increased immunological potential. Journal of virology 73: 225-233 
Jarvis DL (1997) Baculovirus expression vectors. In The baculoviruses, pp 389-431. Springer

Jarvis DL (2009) Baculovirus-insect cell expression systems. Methods in enzymology 463: 191222

Jehle JA, Blissard GW, Bonning BC, Cory JS, Herniou EA, Rohrmann GF, Theilmann DA, Thiem SM, Vlak JM (2006) On the classification and nomenclature of baculoviruses: A proposal for revision. Archives of Virology 151: 1257-1266

Jenison SA, Lemon SM, Baker LN, Newbold JE (1987) Quantitative analysis of hepatitis B virus DNA in saliva and semen of chronically infected homosexual men. Journal of Infectious Diseases 156: $299-307$

Ji X, Sutton G, Evans G, Axford D, Owen R, Stuart DI (2010) How baculovirus polyhedra fit square pegs into round holes to robustly package viruses. The EMBO journal 29: 505-514

Joseph S, David WR (2001) Molecular cloning: a laboratory manual. Gold Spring Harbor, New York

Kawano H, Mifune K, Ohuchi M, Mannen K, Cho S, Hiramatsu K, Shichijo A (1990) Protection against rabies in mice by a cytotoxic $T$ cell clone recognizing the glycoprotein of rabies virus. Journal of general virology 71: 281-287

Kieny M, Lathe R, Drillien R, Spehner D, Skory S, Schmitt D, Wiktor T, Koprowski H, Lecocq J (1984) Expression of rabies virus glycoprotein from a recombinant vaccinia virus. Nature 312: 163-166

King AMQ, Adams MJ, Lefkowitz EJ, Carstens EB (2012) Virus taxonomy: classification and nomenclature of viruses: Ninth Report of the International Committee on Taxonomy of Viruses, Vol. 9: Elsevier.

Klepfer SR, Debouck C, Uffelman J, Jacobs P, Bollen A, Jones EV (1993) Characterization of rabies glycoprotein expressed in yeast. Archives of virology 128: 269-286

Komatsu H, Inui A, Sogo T, Hiejima E, Tateno A, Klenerman P, Fujisawa T (2010) Cellular immunity in children with successful immunoprophylactic treatment for mother-to-child transmission of hepatitis B virus. BMC infectious diseases 10: 1

Koprowski H, Cox H (1948) Studies on Chick Embryo adapted Rabies Virus. I. Culture Characteristics and Pathogenicity. Journal of immunology 60: 533-554

Kost TA, Condreay JP, Jarvis DL (2005) Baculovirus as versatile vectors for protein expression in insect and mammalian cells. Nature biotechnology 23: 567-575

Kotait I, Carrieri ML, Carnieli Júnior P, Castilho JG, Oliveira RdN, Macedo Cl, Ferreira KCS, Achkar SM (2007) Reservatórios silvestres do vírus da raiva: um desafio para a saúde pública. BEPA Boletim Epidemiológico Paulista (Online) 4: 02-08

Krieg A, Franz JM, Groner A (1980) Safety of Entomopathogenic Viruses for Control of Insect Pests. Environ Conserv 7: 158-160

Lai CL, Ratziu V, Yuen M-F, Poynard T (2003) Viral hepatitis B. The Lancet 362: 2089-2094 
Lanford RE, Luckow V, Kennedy R, Dreesman G, Notvall L, Summers M (1989) Expression and characterization of hepatitis $B$ virus surface antigen polypeptides in insect cells with a baculovirus expression system. Journal of virology 63: 1549-1557

Lathe R, Kieny M, Schmitt D, Curtis P, Lecocq J (1983) M13 bacteriophage vectors for the expression of foreign proteins in Escherichia coli: the rabies glycoprotein. Journal of molecular and applied genetics 2: 331-342

Lee WM (1997) Hepatitis B virus infection. New England journal of medicine 337: 1733-1745

Liang T (2000) The molecular virology of hepatitis B virus. American Association for the Study of Liver Diseases-Update on viral hepatitis-Postgraduate Course: 78-82

Locarnini S (2003) Hepatitis B viral resistance: mechanisms and diagnosis. Journal of hepatology 39: $124-132$

Lodmell DL, Esposito JJ, Ewalt LC (2004) Live vaccinia-rabies virus recombinants, but not an inactivated rabies virus cell culture vaccine, protect B-lymphocyte-deficient A/WySnJ mice against rabies: considerations of recombinant defective poxviruses for rabies immunization of immunocompromised individuals. Vaccine 22: 3329-3333

Loza-Rubio E, Rojas E, Gómez L, Olivera M, Gomez-Lim M (2007) Development of an edible rabies vaccine in maize using the Vnukovo strain. Developments in biologicals 131: 477-482

Lu A, Miller LK (1997) Regulation of baculovirus late and very late gene expression. In The baculoviruses, pp 193-216. Springer

Lu Y, Cao W, Hong M, Zhu J, Liu Z, Yang D (2008) [A study on the relationship between point mutation in pre-core region $\mathrm{G} 1896 \mathrm{~A}$ of hepatitis B virus and safety of breast feeding]. Zhonghua yu fang yi xue za zhi [Chinese journal of preventive medicine] 42: 739-741

Luckow VA, Lee SC, Barry GF, Olins PO (1993) Efficient generation of infectious recombinant baculoviruses by site-specific transposon-mediated insertion of foreign genes into a baculovirus genome propagated in Escherichia coli. Journal of virology 67: 4566-4579

Lyons A, Longfield J, Kuschner R, Straight T, Binn L, Seriwatana J, Reitstetter R, Froh IB, Craft D, McNabb K (2008) A double-blind, placebo-controlled study of the safety and immunogenicity of live, oral type 4 and type 7 adenovirus vaccines in adults. Vaccine 26: 2890-2898

Maeda S, Volrath SL, Hanzlik TN, Harper SA, Kei MM, Maddox DW, Hammock BD, Fowler E (1991) Insecticidal Effects of an Insect-Specific Neurotoxin Expressed by a Recombinant Baculovirus. Virology 184: 777-780

Margolis HS, Alter MJ, Hadler SC (1991) Hepatitis B: evolving epidemiology and implications for control. In Seminars in liver disease, Vol. 11, pp 84-92.

McGarvey PB, Hammond J, Dienelt MM, Hooper DC, Fu ZF, Dietzschold B, Koprowski H, Michaels $\mathrm{FH}$ (1995) Expression of the rabies virus glycoprotein in transgenic tomatoes. Biotechnology 13: 1484-1487 
Mebatsion T (2001) Extensive attenuation of rabies virus by simultaneously modifying the dynein light chain binding site in the P protein and replacing Arg333 in the G protein. Journal of virology 75: 11496-11502

Mena JA, Kamen AA (2011) Insect cell technology is a versatile and robust vaccine manufacturing platform. Expert review of vaccines 10: 1063-1081

Miles M, Wallace G, Clarke J (1989) Multiple peptide synthesis (Pepscan method) for the systematic analysis of B-and T-cell epitopes: application to parasite proteins. Parasitology Today 5: $397-400$

Miller LK (1997) The baculoviruses: Springer Science \& Business Media. New York.

Mochizuki H, Schwartz JP, Tanaka K, Brady RO, Reiser J (1998) High-titer human immunodeficiency virus type 1-based vector systems for gene delivery into nondividing cells. Journal of virology 72: 8873-8883

Moreira RC, Deguti MM, Lemos MF, Saraceni CP, Oba IT, Spina AMM, Nascimento-Lima AS, Fares J, Azevedo RS, Gomes-Gouvêa MS (2010) HBV markers in haemodialysis Brazilian patients: a prospective 12-month follow-up. Memórias do Instituto Oswaldo Cruz 105: 107-108

Morimoto K, Hooper DC, Spitsin S, Koprowski H, Dietzschold B (1999) Pathogenicity of different rabies virus variants inversely correlates with apoptosis and rabies virus glycoprotein expression in infected primary neuron cultures. Journal of virology 73: 510-518

Morimoto K, Kawai A, Mifune K (1992) Comparison of rabies virus G proteins produced by cDNAtransfected animal cells that display either inducible or constitutive expression of the gene. Journal of general virology 73: 335-345

Moscardi F (1999) Assessment of the application of baculoviruses for control of Lepidoptera. Annual review of entomology 44: 257-289

Moulton JK, Pepper DA, Jansson RK, Dennehy TJ (2002) Pro-active management of beet armyworm (Lepidoptera : Noctuidae) resistance to tebufenozide and methoxyfenozide: Baseline monitoring, risk assessment, and isolation of resistance. Journal of Economic Entomology 95: 414-424

Nascimento PP, Pinto SGS, Pereira I (2012) Perfil epidemiológico dos marcadores sorológicos para vírus da hepatite $\mathrm{B}$ dos pacientes atendidos em um laboratório público. Revista da Sociedade Brasileira de Clínica Médica 10: 495-498

Neurath A, Kent S, Strick N, Parker K (1986) Identification and chemical synthesis of a host cell receptor binding site on hepatitis $B$ virus. Cell 46: 429-436

$\mathrm{Ng} \mathrm{CT}$, Oldstone MB (2014) IL-10: achieving balance during persistent viral infection. In Interleukin-10 in Health and Disease, pp 129-144. Springer

Nimmerjahn F, Ravetch JV (2005) Divergent immunoglobulin g subclass activity through selective Fc receptor binding. Science 310: 1510-1512

O'Reilly DR, Miller LK, Luckow VA (1992) Baculovirus Expression Vector: A Laboratory Manual WH Freeman and Company. New York 
O'Reilly DR, Miller LK, Luckow VA (1994) Baculovirus expression vectors: a laboratory manual: Oxford University Press on Demand.

OIE. (2016) WORLD ORGANIZATION FOR ANIMAL HEALTH. Rabies., Vol. 2016.

Okanoue T, Minami M (2006) Update of research and management of hepatitis B. Journal of gastroenterology 41: 107-118

Oreilly DR, Miller LK (1991) Improvement of a Baculovirus Pesticide by Deletion of the Egt Gene. Bio-Technol 9: 1086-1089

Paraná R, Kay A, Molinet F, Viana S, Silva LK, Salcedo JM, Tavares-Neto J, Lobato C, Rios-Leite M, Matteoni L (2006) HDV genotypes in the Western Brazilian Amazon region: a preliminary report. The American journal of tropical medicine and hygiene 75: 475-479

Pasteur L (1885) Methode pour prevenir la rage apres morsure, Vol. 101, Comptes Rendus de l'Académie des Sciences.

Pasteur L, Chamberland C, Roux (1881) Sur la rage, Vol. 92, Comptes Rendus de l'Académie des Sciences: Imp. Larousse.

Pasteur L, Chamberland M, Roux M, Thuillier M (1882) Nouveaux faits pour servir a la connaissance de la rage. Comptes Rendus de l'Académie des Sciences 95: 1187

Pawlotsky JM, Dusheiko G, Hatzakis A, Lau D, Lau G, Liang TJ, Locarnini S, Martin P, Richman DD, Zoulim F (2008) Virologic monitoring of hepatitis B virus therapy in clinical trials and practice: recommendations for a standardized approach. Gastroenterology 134: 405-415

Perrin P, Thibodeau L, Sureau P (1985) Rabies immunosome (subunit vaccine) structure and immunogenicity. Pre-and post-exposure protection studies. Vaccine 3: 325-332

Peter G (1997) Summary of major changes in the 1997 red book: Report of the committee on infectious diseases. Pediatrics 100: 109-111

Plotkin SA (2001) Immunologic correlates of protection induced by vaccination. The Pediatric infectious disease journal 20: 63-75

Price PM, Reichelderfer CF, Johansson BE, Kilbourne ED, Acs G (1989) Complementation of recombinant baculoviruses by coinfection with wild-type virus facilitates production in insect larvae of antigenic proteins of hepatitis B virus and influenza virus. Proceedings of the National Academy of Sciences 86: 1453-1456

Rapparini C, Vitória MAdÁ, Lara LTdR (2000) Recomendações para atendimento e acompanhamento de exposição ocupacional a material biológico: HIV e Hepatitis B e C. In Recomendações para atendimento e acompanhamento de exposição ocupacional a material biológico: HIV e Hepatitis B e C.

Ribeiro BMM, F. S. ; ARDISSON-ARAUJO, D. M. P. ; SILVA, L. A. ; CHAVES, L. C. S. ; QUIRINO, M. S. ; ANDRADE, M. S. ; CORREA, R. F. T. (2015) Baculovírus para expressão de proteínas recombinantes em células de insetos. In Biotecnologia Aplicada à Saúde Vol. 2, pp 255-306. In: Rodrigo Ribeiro Resende; Carlos Ricardo Soccol. (Org.) 1ed.São Paulo: Blucher 
Ribeiro BMP, F. J. R. (2001) Baculovirus recombinante para controle de praga. Biotecnologia Ciência \& Desenvolvimento 22: 50-58

Rizzetto M, Ciancio A (2008) Chronic HBV-related liver disease. Molecular aspects of medicine 29: $72-84$

Roberto F (2007) Tratado de Hepatites Virais. São Paulo: Editora Atheneu: 221-229

Rohrmann G (1986) Polyhedrin structure. Journal of General Virology 67: 1499-1513

Rohrmann GF (2013a), 3rdEd edn. Bethesda (MD): National Center for Biotechnology Information (US)

George Rohrmann.

Rohrmann GF (2013b) Baculovirus molecular biology, 3rdEd edn. National Center for Biotechnology Information (Bethesda MD).

Rupprecht CE, Hanlon CA, Hemachudha T (2002) Rabies re-examined. The Lancet infectious diseases 2: 327-343

Saxena S, Sonwane AA, Dahiya SS, Patel CL, Saini M, Rai A, Gupta PK (2009) Induction of immune responses and protection in mice against rabies using a self-replicating RNA vaccine encoding rabies virus glycoprotein. Veterinary microbiology 136: 36-44

Seeger C, Mason WS (2000) Hepatitis B virus biology. Microbiology and Molecular Biology Reviews 64: 51-68

Sellers T (1947) Complications of antirabic treatment. Journal of the Medical Association of Georgia 36: 30

Shankar V, Dietzschold B, Koprowski H (1991) Direct entry of rabies virus into the central nervous system without prior local replication. Journal of virology 65: 2736-2738

Shapiro CN (1993) Epidemiology of hepatitis B. The Pediatric infectious disease journal 12: $433-$ 437

Slootstra JW, Puijk WC, Ligtvoet GJ, Langeveld JP, Meloen RH (1996) Structural aspects of antibody-antigen interaction revealed through small random peptide libraries. Molecular diversity 1: 87-96

Smith GE, Summers MD, Fraser MJ (1983) Production of human beta interferon in insect cells infected with a baculovirus expression vector. Molecular and cellular biology 3: 2156-2165

Smith J, Yager P, Baer G (1996) A rapid fluorescent focus inhibition test (RFFIT) for determining rabies virus-neutralizing antibody. Laboratory techniques in rabies 4: 200-208

Takehara K, Ireland D, Bishop DH (1988) Co-expression of the hepatitis B surface and core antigens using baculovirus multiple expression vectors. Journal of general virology 69: 27632777 
Theze J, Bezier A, Periquet G, Drezen JM, Herniou EA (2011) Paleozoic origin of insect large dsDNA viruses. Proceedings of the National Academy of Sciences 108: 15931-15935

Thomas ED, Reichelderfer CF, Heimpel AM (1972) Accumulation and persistence of a nuclear polyhedrosis virus of the cabbage looper in the field. Journal of Invertebrate Pathology 20: 157164

Tian Y, Xu Y, Zhang Z, Meng Z, Qin L, Lu M, Yang D (2007) The amino acid residues at positions 120 to 123 are crucial for the antigenicity of hepatitis B surface antigen. Journal of clinical microbiology 45: 2971-2978

Tordo N, Poch O, Ermine A, Keith G, Rougeon F (1986) Walking along the rabies genome: is the large GL intergenic region a remnant gene? Proceedings of the National Academy of Sciences 83: 3914-3918

Tordo N, Poch O, Ermine A, Keith G, Rougeon F (1988) Completion of the rabies virus genome sequence determination: highly conserved domains among the $L$ (polymerase) proteins of unsegmented negative-strand RNA viruses. Virology 165: 565-576

Tripatzis I (1972) Australia antigen in urine and feces. American Journal of Diseases of Children 123: $401-404$

Tsiang H (1993) Pathophysiology of rabies virus infection of the nervous system. Advances in virus research 42: 375-412

Van Der Eijk AA, De Man R, Niesters HG, Schalm SW, Zaaijer HL (2006) Hepatitis B virus (HBV) DNA levels and the management of HBV-infected health care workers. Journal of viral hepatitis 13: $2-4$

van Oers MM (2011) Opportunities and challenges for the baculovirus expression system. Journal of invertebrate pathology 107 Suppl: S3-15

van Oers MM, Pijlman GP, Vlak JM (2015) Thirty years of baculovirus--insect cell protein expression: from dark horse to mainstream technology. Journal of General Virology 96: 6-23

Vander Veen RL, Harris DH, Kamrud KI (2012) Alphavirus replicon vaccines. Animal Health Research Reviews 13: 1-9

Vigilato MAN, Clavijo A, KnobI T, Silva HMT, Cosivi O, Schneider MC, Leanes LF, Belotto AJ, Espinal MA (2013) Progress towards eliminating canine rabies: policies and perspectives from Latin America and the Caribbean. Philosophical Transactions of the Royal Society of London B: Biological Sciences 368: 20120143

Villarejos VM, Visoná KA, Alvaro GD, Antonio RA (1974) Role of saliva, urine and feces in the transmission of type B hepatitis. New England Journal of Medicine 291: 1375-1378

Wang S-L, Bentley WE, Liu C-C, Wang M-Y (1999) The use of glucose to regulate $\mathrm{pH}$ values of culture media and increase the production of baculovirus (BmNPV) and foreign protein ( $\mathrm{HBsAg}$ ). Process biochemistry 34: 295-301

Washburn JO, Chan EY, Volkman LE, Aumiller JJ, Jarvis DL (2003a) Early Synthesis of Budded Virus Envelope Fusion Protein GP64 Enhances Autographa californica Multicapsid 
Nucleopolyhedrovirus Virulence in Orally Infected Heliothis virescens. Journal of virology 77: 280-290

Washburn JO, Trudeau D, Wong JF, Volkman LE (2003b) Early pathogenesis of Autographa californicamultiple nucleopolyhedrovirus and Helicoverpa zeasingle nucleopolyhedrovirus in Heliothis virescens: a comparison of the ' $\mathrm{M}$ ' and ' $\mathrm{S}$ ' strategies for establishing fatal infection. Journal of General Virology 84: 343-351

Wen Y, Wang H, Wu H, Yang F, Tripp RA, Hogan RJ, Fu ZF (2011) Rabies virus expressing dendritic cell-activating molecules enhances the innate and adaptive immune response to vaccination. Journal of virology 85: 1634-1644

WHO (2002) Monoclonal antibody cocktail for rabies post exposure treatment: report of a WHO consultation, 23-24 May 2002. World Health Organization document R2-370-15 World Health Organization, Geneva, Switzerland

WHO. (2016) WORLD HEALTH ORGANIZATION. Rabies., Vol. 2016.

Wiktor TJ, Macfarlan RI, Reagan KJ, Dietzschold B, Curtis PJ, Wunner WH, Kieny M-P, Lathe R, Lecocq J-P, Mackett M (1984) Protection from rabies by a vaccinia virus recombinant containing the rabies virus glycoprotein gene. Proceedings of the National Academy of Sciences 81: 71947198

Wunner WH (2007) Rabies Virus. pp 23-68. Elsevier Ltd

Wunner WH, Larson JK, Dietzschold B, Smith CL (1988) The molecular biology of rabies viruses. Review of Infectious Diseases 10: S771-S784

Yao LG, Liu ZC, Zhang XM, Kan YC, Zhou J-J (2007) A highly efficient method for the generation of a recombinant Bombyx mori nuclear-polyhedrosis-virus Bacmid and large-scale expression of foreign proteins in silkworm (B. mori) larvae. Biotechnology and applied biochemistry 48: 45-53

Yue Y, Jiang H, Shi L, Li L, Xi B, Yu Y, Chen G (2004) [Study on the mechanism of intrauterine infection of hepatitis B virus]. Zhonghua Fu Chan Ke Za Zhi 39: 224-226

Zanotto PMD, Kessing BD, Maruniak JE (1993) Phylogenetic Interrelationships among Baculoviruses - Evolutionary Rates and Host Associations. Journal of Invertebrate Pathology 62: 147-164

Zhang L, Fang Z, Zhen Z, Liu X, Gong X, Wu Y (1994) The study of transmission route of HBV from father to infant. Zhonghua Chuanranbing Zazhi 12: 199-201

Zhang Q, Cao G (2011) Genotypes, mutations, and viral load of hepatitis B virus and the risk of hepatocellular carcinoma. Hepatitis Monthly 11: 86-91

Zheng Y, Lu Y, Ye Q, Xia Y, Zhou Y, Yao Q, Wei S (2011) Should chronic hepatitis B mothers breastfeed? a meta analysis. BMC public health 11: 1 